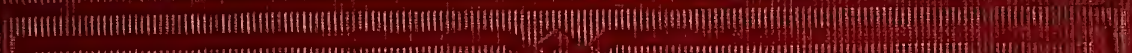
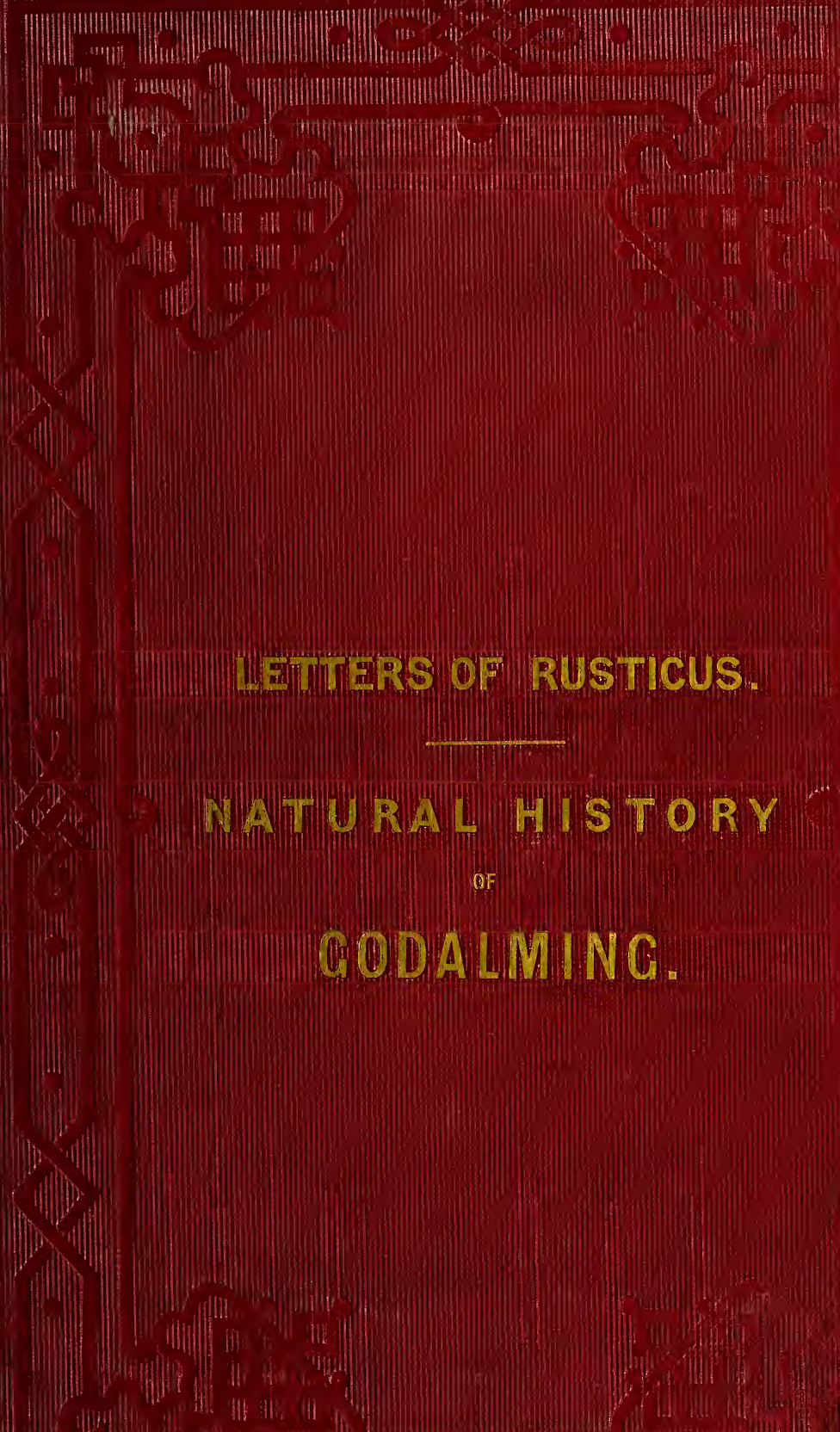


\section{Smithsonian Institution}

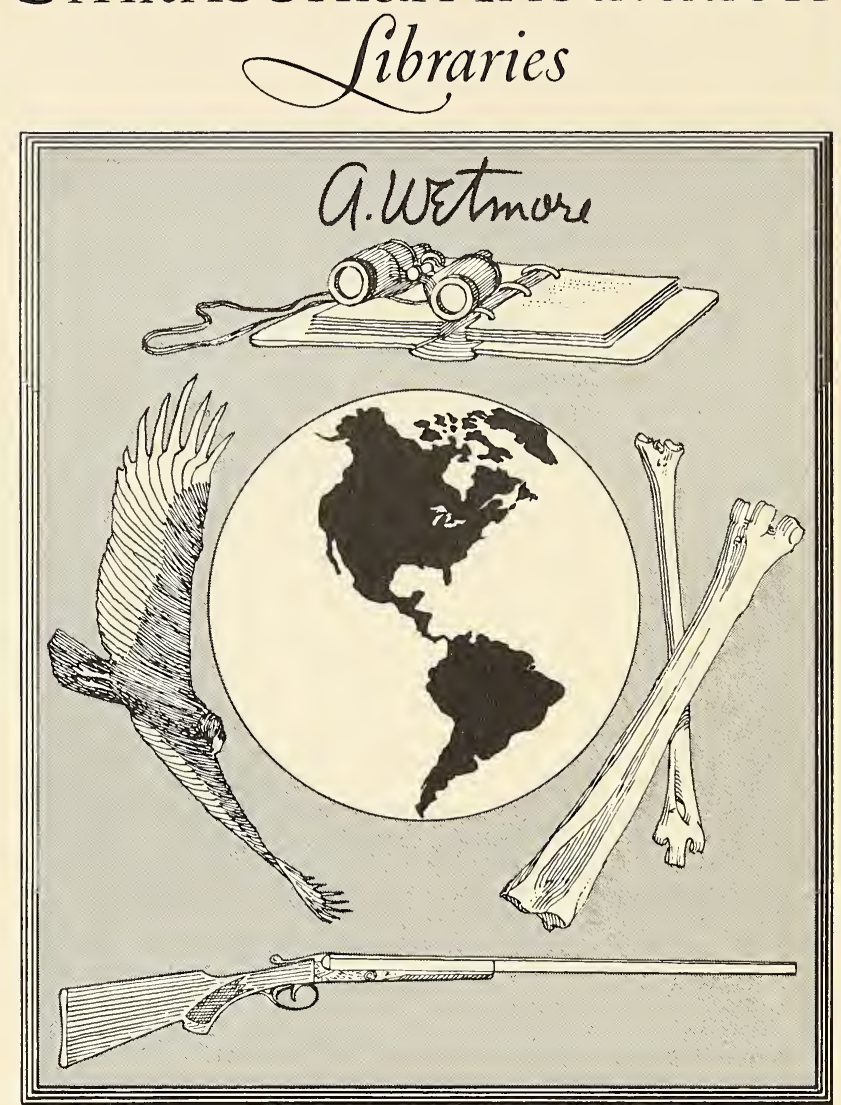

Alexander Wetmore 1946 SixthSecretary 1953

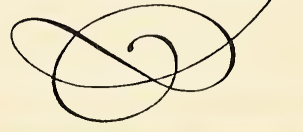


a. Wrtmore 
qu 
THE LETTERS OF RUSTICUS.

and others, 

THE

\title{
LETTERS OF RUSTICUS
}

ON THE

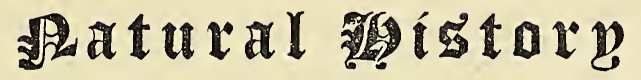

OF

\author{
G O D A L M I N G.
}

EXTRACTED FRON THE

MAGAZINE OF NATURAL HISTORY, THE

\section{ENTOMOLOGICAL MAGAZINE,}

AND THE

\section{ENTOMOLOGIST.}

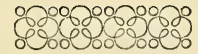

"Stat nominis umbra."

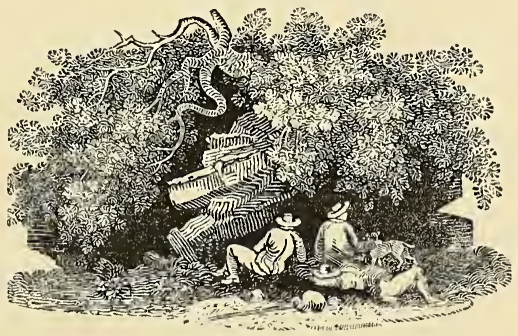

\section{$\operatorname{LONDON:}$}

PRINTED FOR JOHN VAN VOORST, BOOKSELLER AND PUBlisher, No. 1, PATERNOSTER ROW. 


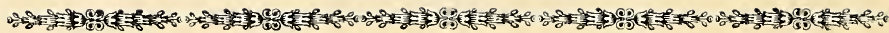

"To me be Nature's volume broad-display'd; And to peruse its all-instructing page, Or, haply catching inspiration thence, Some easy passage, raptured, to translate, My sole delight."-Thомson.

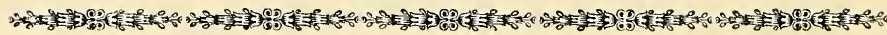




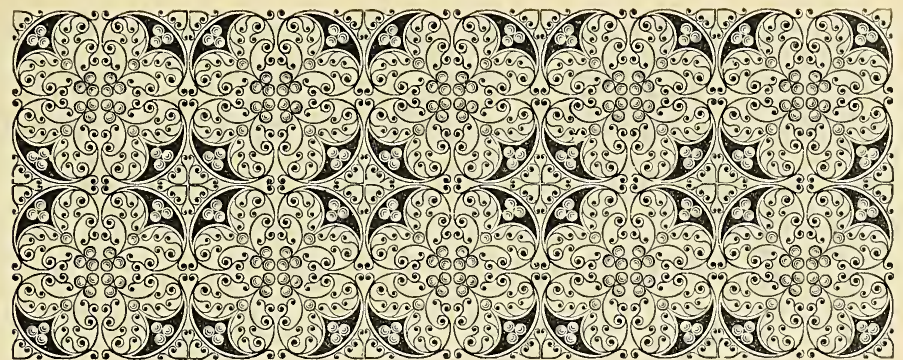

TO THE INDULGENT READER.

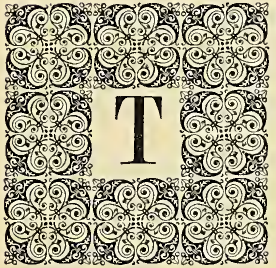

HE papers now for the first time associated, were addressed, many years ago in the form of letters, to the Editors of the 'Magazine of Natural History,' of the 'Entomological Magazine,' and the 'Entomologist.'

For years past I have observed partial reprints of these letters published from time to time, with or without acknowledgment, sometimes tolerably correct, sometimes greatly altered and mutilated; and I have also observed that such partial reprints have been favourably mentioned both by those who produced and those who read them. These circumstances led me to consider the propriety of issuing the whole as a complete although fragmentary work. The copyright had long since passed into my hands, and I had only to deliberate on the chances of the success likely to attend the venture.

Having at length concluded on making the trial, a difficulty arose in finding an editor who would undertake to collect and arrange the papers. This was scarcely a printer's task ; and yet, as I read and re-read letter after letter, I felt so carried back to the scenes of my boyhood, I seemed 
so fully to understand and appreciate the remarks of the writer, I felt so intimately acquainted with the localities, that I at last arrived at the conviction, that although many might bring more ability, none could bring greater good will to the task. If it could be denominated a labour at all, it would at least be a labour of love.

Accordingly in $1845 \mathrm{I}$ commenced the reprint which is only now completed. Having no eager author at my elbow, assuring me that the reading public were languishing for the appearance of the 'Letters of Rusticus', and that their immediate publication was a matter of national importance, I have been very slothful about the matter, returning to it now and then as a kind of relaxation, and have spread over three years what a sanguine author would not have allowed me as many weeks to complete.

For the foot-notes, except where the name of the writer is given, I alone am responsible. I have only appended such as seemed to assist and illustrate the text, endeavouring to abstain from that kind of note-writing which smothers the author under unnecessary comment.

For the use of original sketches of the parish church of Grodalming, Eashing Mill from the Bridge, the Leather Mill on the Wey at the back of Godbold's, and Hatch from the Pond, I am indebted to my kind friend and relation Mr. Waring Kidd. To Mr. Salmon's unwearying assiduity and kindness $\mathbb{I}$ owe the admirable paper on Botany, and a great portion of that on Ornithology. Finally, from the pages of that inexhaustible storehouse of Natural-History lore, the 'Zoologist,' I have extracted several admirable papers, containing collateral evidences from the pens of our best observers.

EDWARD NEWMAN, PRINTER. 


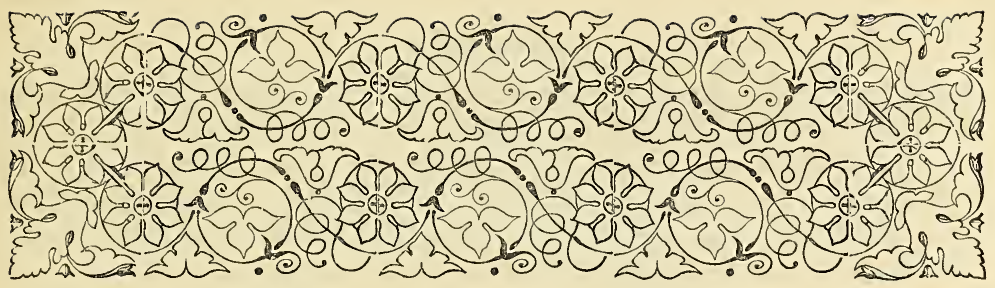

An Account of the Matters contained in this Book.

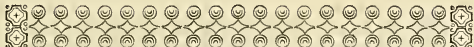

\section{CHAPTER I.}

Situation and Soil of Godalming, 1.-Hollow, sandy Lanes, 3.-Birds'-nesting, 5.-Wild Cat, 6.-Black Grous, 7.- Sand Martin, 8.-Hooded Crow, 9.-Ring Ouzel, 10.-Migration of Birds, 11.-Screech Owl, 12. -Woodcock, 14.-Water Rail, 15.-Eared Grebe, 16.

\section{CHAPTER II.}

Old Pond, 17.-Moorhen, 18.-Titmouse, 19. - Dabchick, 20.-Great Northern Diver, 21.-Wild Swan, 22.--Singing of Swans, 23.

\section{CHAPTER III.}

Fern Owl, 25.-Furze-Wren, 27.-Crossbill, 28. - Siskin, Lesser Redpole, 29. -Chaffinch, Blackcap, 30.-Nightingale, 31 .

\section{CHAPTER IV.}

Trip to the Isle of Wight, 33.-Fresh-water Gate, 34.-Chase of a Smuggler, 35. - Fresh-water Cliffs, 36. - Multitude of Birds, 37. - Unsuccessful Shooting, 38.-Colony of Corvorants, 39.-Passage through the Needles, 41.

\section{CHAPTER V.}

Lobster Pots, 41.-Corvorants, 42.-Sea-birds' Eggs, 43.-Egg Collectors, 44. Eggs stolen by Gulls, and how, 45. - Eggs stolen by Ravens, and how, 46. - Wounded Corvorant, 47. - Crab Race, 48. - Ring Dotterels and Purres, 49.-Singular Larva of Cicindela campestris, 50.-Habits of the Ant-Lion as observed at Marseilles, 52.-Migration, \&c., of Puffin, 53. 


\section{CHAPTER VI.}

Blights, or Insects injurious to Vegetables, 35.- Gooseberry-Grub, 56.-The Fly described, 57.-Laying the Eggs, 58. - The young Grub, 59.-Voracity of the Grubs, 60.-The Grub described, 61.-Change of Skin, 62. - Burrows in the Earth, 63.-Popular Remedies, 64.- Aphis or PlantLouse, 65.-Injury it causes, 66.-Economy of, 67.-Hop-Fly, 73.-Influence on Crop of Hops, 74.- Influence on the Duty, 75.-First Appearance of, 76. - Insect-enemies of, 77.-Remedies, 79. - American Blight, 80.-Apple Weevil, 81.-Descriptions of, 82.-Economy of, 83. Remedies, 84.-Apple-Moth, 85. - Apple-Grub, 86.-Economy of, 87.Little Ermine Moth, 88.-Yellow-Tail, 90.-Turnip-Fly, 91.-Destructive Powers of, 92.-Economy of, 93.- Remedies, 94.-Turnip-Nigger, 99.-Description of Parent Fly, 100.-Economy of, 101.-Description of the Grub, 102.-Remedies, 104.-Turnip-Weevil, 105.-Turnip-Aphis, 106.-Aphides in Apples, Poplar-leaves and on Roots, 106.-Ants and A phides, 108.

\section{CHAPTER VII.}

Hedgehog, 109.-Hibernation of, 110.-Error in defending it as a Herbivorous Animal, 111.-Shown to be a Poacher, 112.-Destroys Vipers, 113, and is generally Carnivorous, 115.-Long-tailed Tit, 116.-Dabchick, 117.-Hare, 118.-Weasel hunts Rats, 119, as well as Rabbits, 121.Flowering of the Aspen, 122.-Coccus of the Vine, 123.-Flies and Humble-Bees, 125.-Burying-Beetle in Russia, 127, in England, 128.

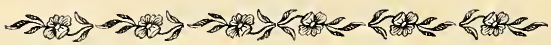

\section{APPENDIX.}

A. An Outline of the Flora of the Neighbourhood of Godalming, in the County of Surrey; with Brief Notices of the Geological Features of the District. By J. D. Salmon, Esq., 131.

B. Account of the Black Canker Caterpillar, which destroys the Turnips in Norfolk. By William Marshall, Esq. Published in the 'Philosophical Transactions' of the Royal Society for 1783, 146.

C. An Outline of the Ornithology of Godalming, in the County of Surrey; with brief Records of some of the Rarer Birds. By Edward Newman, 150.

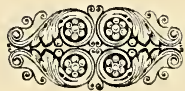




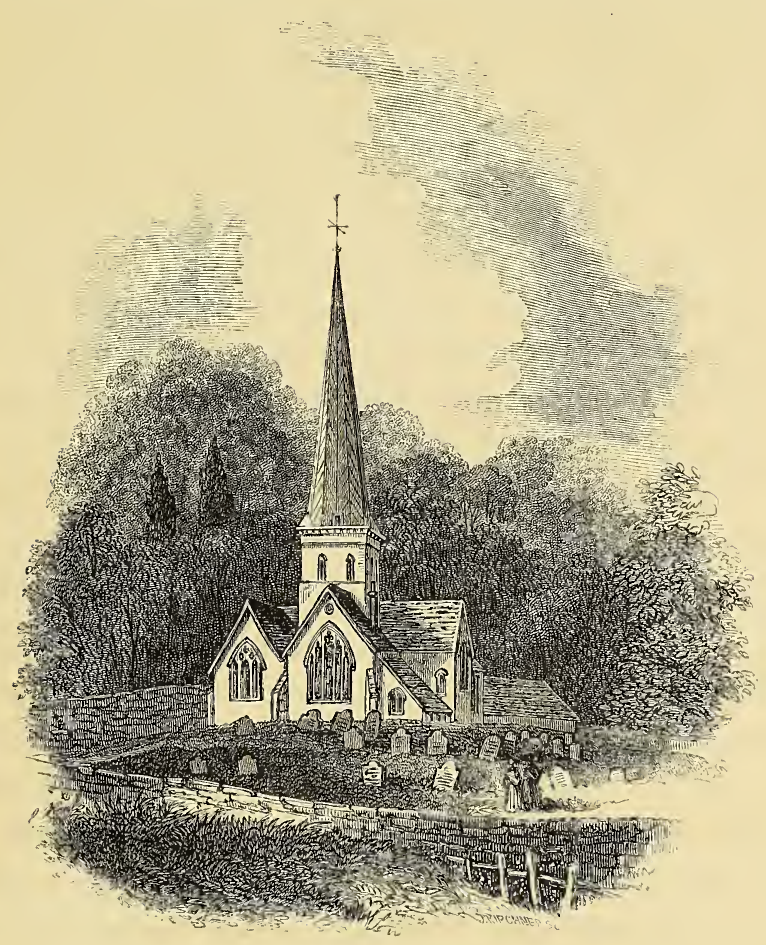

THE PARISH CHURCH OF GODALMING

\section{CHAPTER I.}

Godalming is situate thirty-four miles S.S.W. of London, in the county of Surrey; the town stands in a low situation on the river Wey, and is completely surrounded by little hills, the various ascents of which present pleasing prospects in every direction. The soil is a bright red sand, which extends from the chalky range of cold, poverty- 
stricken downs crossing the country from Reigate to Farnham. Between the chalk and the sand is an exceedingly narrow tract of blue clay, sometimes scarcely ten yards in width. These three distinct soils do not gradually intermingle, but are separated by the most abrupt transition, and their effect on the produce, where the three soils occur in the same field, is very marked. The sandy soil produces a variety of surface; in most parts it is excessively poor, and wholly unprofitable to man: in some of the low bottoms it becomes an almost continuous marsh, occasionally presenting large sheets of water ; these ponds, in the process of time, enrich the soil which they cover, and make it worth the expense of draining; - thus, the once fine piece of water known as Old Pond, has been embanked, divided, drained and filled, at different times and in various ways, until nearly an hundred acres have been redeemed and devoted to agriculture; still, it is a pool of respectable dimensions.* In many places, this labour would be ill bestowed, and there are fine pools of water which have existed for centuries all along the valley that winds by Peperharrow, Elsted, Frensham, Thursley, the Pudmoors, Headly, \&c. Ascending thence by Bramshot to Liphook, we find a tract producing coarse sour grass, heath, furze and hurts, or whortleberries, but light and dry, and easily scattered by the wind; this is a peculiar character of Hindhead. Wherever the sand bears the red tint of iron, the chief natural produce is furze; but this colour, as we proceed westward, yields to a blue tint. The two colours stain the wool of the sheep which range the wastes, and the red and blue are very conspicuous in their fleeces, the blue

$$
\text { * In } 1832 .-E . N \text {. }
$$


being much preferred. The chief natural produce of the blue sand is heath, of the three usual species, which are very apt to be completely matted together with dodder. The moors or wet places in this sandy waste produce immense quantities of the beautiful little sundew, and many of those plants which mark a boggy surface. The Devil's Punch-bowl, one of the hollows of Hindhead, has long been celebrated for its abundant crops of whortleberries and the magnificence of its Flowering Fern, which here grows to a height of four feet.

Notwithstanding the general bareness of the surrounding country, a character common to all the western division of the county, the hills in the immediate neighbourhood of Godalming are completely covered with coppices, abounding with trees in all stages of growth, so as to form an excellent resort for the perching birds. In the underwood of these hills the shy hawfinch breeds annually, and remains throughout the year; but the parent birds are difficult to obtain, flying the instant they catch sight of a gunner, although many hundred yards distant.

The fir-trees on the higher grounds are frequently the resort of whole troops of crossbills. The higher trees in the coppices are often selected as building-places by the carrion crow and magpie; the latter, however, is not a very common bird in this district.

In many places among our little hills, we have deep hollow sandy lanes, with steep banks, and great thick hedges on each side a-top ; hedges run to seed, as it were, and here and there grown into trees - gnarled oak, bushy rough-coated maples, and so forth - trees, in fact, that, stretching their arms from both sides of the way, shake hands over your head, and form a kind of canopy of 
boughs. In some spots the polypody, twisting and interlacing its creeping scaly stem with the tough, half-exposed roots of hazel, maple, oak and hawthorn, grows in such luxuriance and profusion, that its gold-dotted fronds hang by thousands - aye, hundreds of thousands - over the stumps and roots, forming the most graceful of coverings. Here and there are great tufts of hart's-tongue, with its bright, broad, shining, wavy leaves. Here and there, where water has filtered through chinks in the sandstone, so as to keep up a streak of moisture down the bank, we have lady-fern and a host of mosses. Here and there, in holes - little cavernous recesses - the face of the damp sand or sandstone is powdered over with a diversity of lichens. Here and there the lithe snake-like honeysuckle twines round the straight upright young stems of the nuttree, cutting deeply into their substance, and forcing them out of their stiff propriety into strange corkscrew forms :up it goes, and getting above the heads of its supporters, spreads its own sweet laughing blossoms to the sun. Here and there is a dense network of the wild clematis, clothed with downy seeds - a plant so loved by Scott, that, with a poet's licence, he transplanted it from our warm hedgerows to the cold rocky scenery of Ketturin and Venue, a botanical blunder which few of his readers will detect and none criticise severely. I love these lanes, because Nature has so long had her own way in them; and where Nature is left to herself, she always acts wisely, beautifully and well. There is not a foot of surface in these old hollow ways, but has its peculiar charms.

To lovers of birds such lanes have special attractions, for they abound in those wild-briary thickets in which our summer birds delight to hide themselves and to nestle. 
When the lengthening days give the first impulse to the feathered tribes to bend their course northward for the breeding-season, it is here that I listen for the first notes of the chiff-chaff: here I watch for the blackcap, the nightingale, the willow-wrens, the garden warblers, the whitethroat; here hour after hour have I hunted for their nests, my object not being plunder, but information. Often have I covered my hand with scratches, from the prickles of briars and brambles, in my attempts to gain a satisfactory view of a nest and its contents without causing any disarrangement, well knowing how great was the risk of desertion if the parent birds should discover anything amiss; and when deserted, if I knew not the builders, a nest was valueless. How well was I repaid for bleeding hands, if I discovered but one point in the history of a species. Eggs strung on bents are rife in all country places; old nests are easy to be seen when the leaves are gone; birds are plentiful in every hedge-row, and their song is the burthen of the passing breeze : but to connect with certainty each bird with its mate; to assign it the proper nest and proper eggs ; to learn the exact time of its amival and its departure; all this is a study, a labour, rarely undertaken, and affords a pleasure akin to that which must be felt by a traveller exploring countries where man has not before trodden.

South of Godalming, the sand is succeeded by a deep clay, extremely favourable to the growth of timber. This district is densely wooded, the woods, in some instances, covering hundreds of acres. In this tract is situated Blunden's, a beautifully wooded place, once the property of the late Henry Hare Townsend, Esq., but lately in the possession of Mr. Mellersh, whose keeper and factotum, 
Chalcraft, once had the extraordinary luck to trap a WILD $\mathrm{C}_{A} \mathbf{T}$, the rarest of British quadrupeds: not an old Tom turned poacher, as some of my readers will at once conclude, but a true, genuine, wild cat. And here let me say that there is not more difference between a Newfoundland dog and a cur fox,-between a red deer and a roebuck, between a barn-door hen and a hen pheasant, - than between the ferocious tiger of our woods and the purring mouser of our hearths. Chalcraft brought his prize in triumph to Hatch, so long the residence of $\mathrm{Mr}$. Waring Kidd: but poor Waring was 'hors de combat,' - regularly on the sick list, he was often ailing, - and he had not nerve enough to undertake the embalming and preservation of so vast a beast. Chalcraft was sadly disappointed, but solaced himself by making a fur cap of the skin, which he wears on great occasions to this day. Out-lying tabbies are not uncommon, and destroy lots of young pheasants, but this is the only instance within my knowledge of the capture of a real wild cat.

From time immemorial Brack Grous have inhabited Hindhead. This noble bird usually prefers wet swampy places: I have known a pointer, when up to his knees in water, stand at a 'black cock:' but occasionally, especially towards August, the black grous get upon the brows of the hills, and then is the time when they are principally sought after by sportsmen. It has always been a riddle to me that Gilbert White should speak of the black cock as extinct. I can truly say with him, "When I was a little boy, a black cock used to come now and then to my father's table." But this is not all ; the sportsmen here kill them every year. I believe Mr. Wheeler and some of the Paynes go out regularly on the 12th of August, and always 
bag some grous, - from two to four brace : their beat is about Churt, a district well known to sportsmen. But I can speak from more positive knowledge than this. On one occasion Waring Kidd, Mr. Mellersh, his man Friday - I mean Chalcraft, - and Dick Rook, completed the party. I must introduce Dick Rook: he was a character, and so was his father; they both followed ostensibly the calling of 'broom-squarer', that is, they cut the common ling for the purpose of making brooms: both, however, dabbled a little in other matters. The father bred game cocks, and made a good bit of money by them too; he lived in Acham-bottom, in such a dilapidated dwelling that you might see the sky through every ceiling in the house. Dick liked anything better than work, and was always at the service of any gunner who would give him a day's employ as fag and marker : and a better marker never lived; he would mark a covey of partridges with a nicety, a truth, that I have never seen approached, much less equalled. But to return to the black cock. We - I should say they - were beating the hill-side, all abreast, and at regular distances, when Dick said to Waring, _ "Now, Sir, keep higher up, he lays just yonder," pointing higher up the brow; " if you keep well up you'll be sure to flush him, and have the first shot; he'll fly across Mr. Mellersh as he goes towards the bottom." This arrangement was agreed on ; and while Waring was working upwards, Mellersh moved a few yards downwards; and Dick, who knew to an inch where the black cock lay, mended his pace and walked right into him. Up rose the fine old fellow, spread his curly tail, and was going off like the wind. "Mark," cried Dick, with ill-suppressed pleasure, for he made sure he had saved his bird: but as the word left his lips, the 
grous threw a summerset in the air, and fell lifeless among the heather: he had received a retainer from Waring, although at a distance of more than eighty yards : a single shot, as we afterwards found, had lodged in his heart. Dick threw up his hat, and shouted at the top of his voice, "Well done Godalming!" I shall never forget the scene: Dick's keen relish for such an exploit overcame his itch for the few shillings the bird would have brought him if it had fallen into his own hands. I recollect on another occasion, Waring bagged a 'gray hen,' and Mr. Sam Kidd another. But the great destruction of the black game, and its consequent scarcity, is attributable to the unceasing persecution of the broom-squarers, most of whom have old rusty muskets, that once belonged to the volunteers. Armed with these, they follow the birds day and night, especially in deep snow, when it is easy to track them.

Almost all our sand-banks are honey-combed by the SAND-MARTIN ; but in many places the original excavators have been dispossessed by the House Sparrow. This is particularly the case at the Holloway-hill sand-bank, and at Catherine Hill, between Godalming and Guildford. It is the work of every spring to dig new burrows, for some of the old ones are sure to be tenanted by sparrows before the return of the rightful proprietors. This robbery seems to be submitted to, almost as a matter of course. For a few days we have a little chattering, a little scolding, a little hustling, but no warfare : the hard horny beak of the robber is too formidable a weapon for the weak and delicate martin to contend with; so he bores a new hole by the side of the old one, and lives on the best possible terms with his neighbour - the rogue who has turned him out of house and home. With us, the sand-martins are grega- 
rious, associating in large colonies; but I observed, when once in Scotland, that there you never see more than a pair at a time, and that not often : you may walk for days without meeting with this bird at all.

In severe winters, the Hooded Crow is common enough all up the valley of the Wey. The common between Godalming and Guildford is a favourite resort with him; and you can hardly pass along this way without seeing several. They stay in the road in the most fearless manner, till the horses of a coach are within twenty yards of them, and, on being disturbed, take a short circuit, and settle again almost on the spot they rose from. The arrival of this crow from the north takes place in October and November, and his return in March. I know no instance of his breeding here, or ever being seen here in summer. In the winter of 1813-14, these crows, as well as the common crow and lots of ringdoves, used to come into our garden, to eat the leaves of the greens ; and so severely did they punish the whole of the cabbage and brocoli tribes, that we got nothing at all from the stumps, when the warm weather ought to have set them sprouting. The tops of the plants were pecked into shreds, and stuck up like a parcel of brushes; and so remained. But the most remarkable feature of that terrible winter - as regards birds - was the number of skylarks that it actually starved to death. They wandered about in flocks, from field to field, from garden to garden, till they became mere bags of bones, and sometimes of a morning you might find them frozen to the surface of the ground: and when we drove up the survivors, in the garden or the field, how forlorn was their look, how weak their flight, how woe-begone their roice, how different in all respects from the happy 
skylark of the summer, overflowing with happiness and complacency, and half bursting with song!

The Ring Ousel is another bird of passage that visits us with the greatest regularity in spring and autumn ; but our winter is too cold for him, I suppose, for he never stays above three weeks in autumn, then passing southwards towards the Sussex coast: in the spring his stay is still shorter, as he is then in a hurry to get to his home among the hills of the north, where he nestles. Hindhead is the resting-place of the ring ousel on both his passages, and he keeps about the tops of the hills. Stragglers have been shot at Rodborough and on Highdown's Ball, but this is a rare occurrence.

The migration of birds is a study in which our ornithologists have not yet made any great progress. White and Bewick have touched on it, but not quite satisfactorily; they point to migration as a kind of a tree of knowledge, whose produce, as that of the old one, is forbidden fruit. Now migration is the simplest thing in the world. At certain periods of the year the proper food of certain species of birds fails in the native countries of those species; this is the 'cause' of migration: then the first 'law' of migration is the 'instinctive - and perhaps in some instances experimental-knowledge that proper food is about to fail.' The next important facts are, that the great mass of birds of passage are insect-eaters, and secondly, that insects, at the approach of winter, disappear first from the most northerly countries: if water-birds or waders, still the facts obtain ; the freezing of lakes, rivers and mud-banks first occurs in the higher latitudes : hence the second law, that ' migration is in a southward direction.' Thus, migration begins in autumn and goes on till winter, keeping pace 
with the failure of certain kinds of food. No sooner does spring return and promise abundance of food, than all the feathered tribes return northward, to dwell and to rear their young in the very places where they themselves were reared. 'The country of all species is not the same: thus redwings and fieldfares bred in Scandinavia return to Scandinavia; and because they feed on hips and haws, they go just so far south as to procure a supply. The ring ousel breeds in Caernarvonshire, Derbyshire, Yorkshire, and Lancashire, but not finding sufficient food there, nor yet in our southern counties, nor yet even in France or Spain, all of which it crosses, it goes on into the warmer regions of Africa. Well, then there is our dear darling nightingale, that homes in Surrey, despising the inclement regions of the north; he, too, turns his face southward at the same time and for the same cause as the redwing, the fieldfare and the ring ousel; and he, too, passes onward into Africa. The very birds of prey, if also birds of passage, perform their journeys in the same direction.*

* There are passages in Mr. Yarrell's ' History of British Birds' that lead me to fear that even he entertains confused if not erroneous notions on the interesting subject of migration. Among those passages I have marked, I select the following, because it bears on the birds mentioned in the foregoing remarks, enclosing between parentheses the part that seems erroneous. "The ring ousel is a summer visiter to the British Islands : and, (although its migrations are decidedly opposite as to season to those of the fieldfare and redwing), which visit us in winter, all three pass the coldest weather in the warmer parts of Europe, and the countries a little further to the south of it, and all three likewise pass the summer in the more central or northern parts." - Birds, i. 207. Instead of the migrations of these birds being ' decidedly opposite,' our information shows us that they are closely approximate, not only as regards season, but also as regards direction. Even Gilbert White, the great ornithologist of lis day, boggles at the movements of the ring ousel: at first he concludes, without any other ground cxcepting that of analogy, that "its autumual migration is southward." Afterwards he says, in the 26th letter addressed to Pennant,- 
Waring and I make out a list of eleven hawks and five owls that either reside in or visit the Godalming district. The hawks are the osprey or gull-hawk, the sparrow-hawk, the peregrine, the hobby, the merlin, the kestrel, the buzzard, the honey-buzzard, the moor-buzzard, the hen harrier, and the ash-coloured harrier; and the owls are the screech-owl, the hooting or tawny owl, the long-horned owl, the short-horned owl and the little horned owl.

I think I was the first to notice a rather odd family arrangement of the ScreEch OwL, at least it was not known to the bigwigs in these matters about Godalming: it is, that a pair of screech owls will bring up two or three families of owlets at once.* There may be three pairs of owlets, all requiring the attention of the old ones at the same time; one pair three parts grown, one pair half

"I have good reason to suspect since, that they may come to us from the westward." In the 37 th letter, addressed to Pennant, we find on the authority of that naturalist, that "they are resident in those cold regions the whole year." And finally, as a last passage on the subject, I find in the 51st letter, addressed to Daines Barrington, the following inconclusive conclusion. "Hence we may conclude that their migrations are only internal, and not extended to the continent southward, if they do at first come at all from the northern parts of this island only, and not from the north of Europe."-E. N.

* It seems needful to state that this peculiar economy of the screech-owl was noticed by Mr. Blyth in the 'Magazine of Natural History.' "A nest of the barn owl last summer, in this neighbourhood, contained two eggs, and when these were hatched two more were laid, which latter were probably hatched by the warmth of the young birds; a third laying took place after the latter were liatched, and the nest at last contained six young owls, of three different ages, which are all reared."-Mag. Nat. Hist. v. 9. I think the supposition that the eggs of the later broods were hatehed by the warmth of the elder owlets, a remarkably good one, since the providing food for such a family must find sufficient employment for the old ones. The usual record of ' Natural Histories,' that the barn owl has five or six young ones to a brood, is not borne out by any of the above remarks; and I can state from actual observation that two is a common number. $-E$. $N$. 
grown, one pair a quarter grown. Now this is a wonderful and wise provision of Nature; for these owlets are ravenous beyond all belief, and the old ones are for everlasting at work to keep them well supplied with rats and mice. I reckon a screech-owl's nest - ' establishment' is a better word - is a regular blessing to the neighbourhood. A screech-owl nestles in that luge aspen at the gate, going into Godbold's; and although we are told that 'two of a trade never can agree,' yet the hooter breeds there too, and I never heard but that both species followed their mousing propensities in perfect amity.

But now to my tale. One day in October, 1822, I was sauntering along a lane between Munsted and Hascomb, when just as I passed a great pollard oak, I saw a screechowl come out of a hole from which had once issued a tolerably large branch. I tapped the trunk with the but end of my gun, and immediately heard a response from within, that noise which Bewick calls snoring. Of course, I laid down my gun and climbed the tree, which was certainly one of the toughest I ever undertook: there was scarcely a twig to hold by, and the trunk was uncomfortably large. I think the top of this tree must have been snapped off by the wind, or perhaps struck by lightning at some remote time, for a lot of short and thick worm-eaten splinters stuck up amongst vigorous boughs, giving the tree a very odd appearance. The treat of inspecting the interior was not to be obtained; so I put on a thick leather glove, and thrust my arm up to the shoulder into the hole whence Mr. Gillihowlet made his exit. The produce of the first grasp was an owlet of very respectable size: quite three parts grown, and too well feathered to be trusted alone, so I buttoned him in the pocket of my shooting-jacket, and 
tried my luck again : this time an owlet came to light, less than half the size of the first, and apparently youthful in proportion to his littleness; he also was consigned to the pocket, and then a third, exactly like the second. After a good deal of groping about, I felt pretty sure there were no more owls or owlets to be found, but there was some- . thing very much like eggs. So I ventured to feel with an ungloved hand, and brought out three eggs, one at a time; they were very warm, and were half buried in something like highly dried pulverized mice, which I presume to have been produced by long trampling on the pellets cast up by the old owls. Having carefully deposited one egg in each waistcoat-pocket, and a third in my mouth, and having screwed up in paper some of the dust, I commenced my descent, and landing in safety, sat down to examine my treasures. One of the old owls returned in the mean time, perched on a bough at a little distance, and strove to look as philosophical as possible under her loss. Determined to understand as much as possible of the economy of this ' happy family,' I proceeded to pierce the eggs. One was addled, this was not the one I brought down in my mouth, the others were 'sot-hard,' as our countrymen express it: the owlets were too far advanced towards hatching, to permit of the eggs being blown.

Woodcocks frequently breed with us. I recollect meeting with young ones on many occasions. Once in particular I remember putting up an old hen and three young ones, two-thirds grown, when rabbit-shooting in a field called the 'fourteen acres,' adjoining Munsted farm, and belonging to the Milford estate. We have two kinds of woodcock, the little black cock, which is comparatively rare, and the large pale cock, which is common. I have 
always supposed the little black cock to be the male, and the other the female; but I have no evidence of this, and our best sportsmen think differently, and urge the difference in number, which is as fifty to one, the difference in size, which is as great as between a full snipe and a Jack, the difference in colour, and a difference in the comparative length of the beak and shank.

We have the Water-RAIL common enough about Godalming. Those which have crossed the sea, return before the 'land-rail' or ' daker' by about ten days. We expect the water-rail on the 7th, the land-rail on the 17 th of April, and both keep their time with most commendable punctuality. The water-rail's haunt near the town is usually called the 'Withy-beds,' low swampy covers, full of willows, alders, and coarse sedge and grass, that run along the side of the Wey, between the wharf and Sweetapple's paper-mill at Catteshall. A second place he condescends to patronize is a swampy cover by the river at Godbold's, among highish trees : and a third is the willow-bed at the top of Ocford water, I have no doubt that the water-rail breeds in all these places, for in all of them you may continually hear that strange, wild, powerful, shrill, halfwhistling kind of a call, which he utters in the breedingseason : a call, by the way, that used sorely to plague me, until I saw the bird actually utter it. I once heard it so distinct and loud that I was sure the bird was close to me; so I stood as still as a post, and watched the bird skulking about among the great tumps of sedge, and saw him stand still and call. The only nest I have ever positively seen, was in the willow-bed at Ocford-water: I did not find it till the young birds were gone, and then there were two addled eggs and the fragments of five egg-shells in it. 
Although I can boast of but this one instance of seeing a water-rail's nest, you may be sure they are not uncommon here, but these birds live in places where humans can't follow them : the spaces between the great sedge-tumps look nice enough, something like custard with nutmeg grated over it, and just as soft. I should add that all birds of this species, but more particularly the young ones, have a weak and languid flight: great numbers of the birds of the year are quite unable to cross the sea, so that when the autumnal or southward migration sets in, we have arrivals of water-rails from the north; many of which, as well perhaps as the birds bred with us, stay here during the winter. I have often killed them when snipe-shooting; three or four of a morning.*

The EAREd Grebe is resident in one locality, Forked Pond, a very pretty lake-like piece of water on the Peperharrow estate; a portion of the pond is in the park, and here its margin is wooded and picturesque, but towards the silk-mills, at the Hammerponds end, it is more exposed. On this pond I have observed these rare grebes many following seasons, not in great numbers, but two or three pairs, and they always keep out in the middle of the pond. Mr. Henry Moline has a fine pair, which were probably killed at this pond, having been sent to him by the late Mr. Howard, of Elsted, but without the requisite information as to locality.

* The reader is referred to several papers in 'The Zoologist' touching the migration of the water-rail (Zool. 148, 575, 669, 766 and 796), by which it will he seen that its migrations are still but imperfectly understood. $-E . N$. 


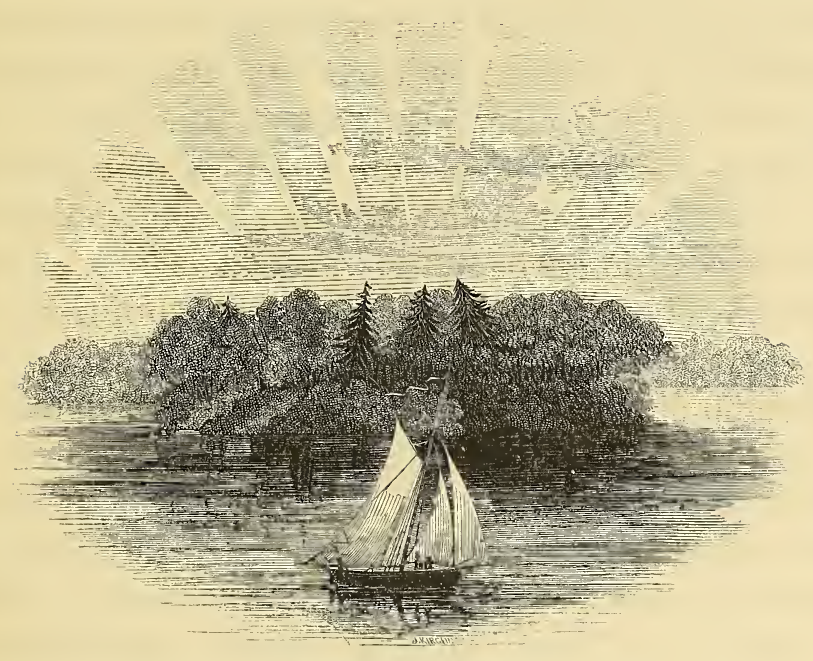

THE ISLAND IN OLD POND.

\section{CHAPTER II.}

THE piece of water called Old Pond, about one mile from Godalming, on the London road, is a most attractive spot to waterfowl; and an island in its centre is the resort of some of them in the breeding season, and also of a variety of other birds, which find it a safe and unmolested place for the same purpose. I have often delighted, in years that are gone, to visit this island and its inmates; the owner, Mr. Robert Moline, used to allow us free ingress to all and every part of the estate; a liberty of which any one, with an incipient thirst for a knowledge of Natural History, would be sure to avail himself. One day, having pushed off from the shore, and moored the little shallop to 
some of the osiers which surround the island, I began my accustomed examination: the first object that attracted my attention was a lot of dry rushes, flags, reeds, \&c., enough to fill a couple of bushel baskets. This mass was lodged about twenty feet from the ground, in a spruce fir tree, and looked for all the world as if it had been pitched there with a hay-fork. I mounted instantly, thinking of herons, eagles, and a variety of other wonders : just as my head reached the nest, flap, flap, out came a Moorhen, and, dropping to the water, made off in a direct line along its surface, dip-dip-dip-dipping with its toes (they do this just to cool their toes, I have often conjectured), and was at last lost in the rushes of a distant bank, leaving an evanescent track along the water, like that occasioned by a stone which has been skilfully thrown to make "ducks and drakes." The nest contained seven eggs, warm as a toast. The situation was a very odd one for a moorhen's nest; but there was a reason for it: the rising of the water in the pond frequently flooded the banks of the island, and as I had before witnessed, had destroyed sereral broods by immersion.**

* I have frequently had an opportunity of observing a peculiar fact with regard to the moorhen, to which an explanation was I believe first offered by the Rev. J. C. Atkinson, at page $\mathbf{7 6 7}$ of the 'Zoologist.' I allude to the building of supplementary nests, or nests not designed for the usual office of incubation : these nests are generally manufactured about hatching time, and it has been conjectured their object is to receive part of the young ones when they have become too large to be accommodated in the old nest: so that some are supposed to use one nest and some the other. This idea seems, however, to require confirmation, more especially as supplementary nests, or nests not devoted to incubation, are by no means of uncommon occurrence. I have known the common wren build at all times of the year, and employ an autumn-built nest as a house of nightly resort throughout the winter: indeed, boys at school are perfectly familiar with these nests, and designate them 'cocks' nests,' believing they are tenanted only by the male wrens: but, quite independently of any apparent 
The next object of attention was a Titmouse, of the large black-headed kind, swinging himself about like a rope-dancer, and whistling out his sing-song just like a fellow sharpening a saw. To my surprise, the gentleman entered an old magpie's nest, to which I had paid frequent friendly visits during the previous spring; he immediately came out again, and jumped about, sharpening his saw as before. One might almost as well handle a hedgehog as a magpie's nest : in this instance some cuttings of gooseberry bushes, skilfully interwoven into an arch above it, rendered it rather more untempting than usual. I was meditating how to commence the attack, when another tomtit flew out in great choler, and rated at me as though I had already robbed her: after a good deal of trouble, during which the slender fir-top was swinging about with me in the breeze, I succeeded in obtaining a peep into the nest: there was nest within nest: the cosiest, softest, warmest little nest, with eight delicately speckled eggs, at the bottom of the magpie's more spacious habitation. I declined meddling with them, whether on account of the awkwardness of my situation, or the intervening gooseberry bushes, or the cruelty, I will not say.

I have occasionally, though but seldom, found the $\mathrm{D}_{\mathrm{AB}}$ CHICK's nest in the weeds near the banks of this island: it is large for the bird, but of very inconsiderable thickness, and always wet, so that the eggs are for ever in a sort of puddle. The eggs are about as big as a blackbird's, but

design, there is such a building impetus in birds that it is no uncommon occurrence for the same pair to commence half-a-dozen nests besides the one which contains the brood: I speak of birds in a state of nature, but the same propensity is exemplitied among birds in aviaries, where single birds, male or female, are continually displaying their constructive abilities.-E. $N$. 
rather longer : when only two or three, they are white and uncovered, but when more, they are carefully concealed,* principally with the flowers of the common reed; and this is not to be done at a moment's notice, when you drive the bird from her nest; there are no reeds near enough for

* The fact of the dabchick covering its eggs has been confirmed by many excellent observers since the preceding paragraph was published; and several interesting particulars have been detailed in the 'Zoologist,' both as regards the covering and the colour of the eggs. "Their nests" says Mr. Parsons "are placed in the thick water-plants or reeds growing upon the sides of the marshy waters, and consist of a large quantity of material - flags, reeds, or any aquatic plants, sometimes of rushes broken into short pieces, and built upon a solid foundation from the bottom, to six inches or a foot above the surface, subject to variation from the rising or wasting of the water. Upon the top of this fabric are deposited from four to six eggs, perfectly white when first laid, but soon stained by being in contact with the moist plants, so that they may fiequently be seen of a dark brown. When the complement of eggs is nearly completed, they are carefully covered over, but the birds are not so particular at first, as I have often seen nests with one or two eggs left uncovered ; afterwards, and during the time of incubation, they are concealed by a larger covering, not, as Professor Rennie tells us, of dry hay, which is often a scarce commodity in the dabchicks' haunts, but with the water-plants or rushes growing hard by, and one plant, the water crowfoot, appears to be a favourite with them for this purpose." Mr. Parsons goes on to observe, that from the quantity of "this corering, it is obvious that it is not hastily placed on when quitting the nest:" it must be a work of time and labour, and when once accomplished "the covering is allowed to remain, the bird performing her duties of incubation upon the top of it," a situation Mr. Parsons has sometimes surprised her in, when she has suddenly plunged into the water, leaving " both the eggs and covering. quite warm." The reader is referred to this account at page 365 of the 'Zoologist,' to others by the Rev. Mr. Atkinson, at pages 499 and 767 , and to a fourth by the Rev. Mr. Bury, at page 863 . These admirable papers are of the highest possible interest, and together contain an excellent history of this amusing bird. From the mass of evidence on the subject, it may be gathered that the eggs of the dabchick are rarely covered until three at least lave been deposited: that the total number is five or six : that they are always in contact with the water: that during incubation they are always covered, the parent bird sitting on the covering: and finally, that this incubation among wet and decaying weeds is a highly probable cause for that strange discolouring for which the dabchick's eggs have always been remarkable. 
that: but she sits on the eggs, reeds and all, and the eggs are then of a dingy brown.

A very fine specimen of the Imber, or Great Northern Diver, was shot a few years back, on Old Pond: its power of diving, and the length of time it stayed under water, were wonderful; for this purpose I find it is furnished with an immense bladder, extending the whole length of its neck, which it can inflate at pleasure, and, this being connected with the windpipe, is of course available as a reservoir of air. The capture of this bird, after a residence of about a fortnight, was quite an event in the annals of Old Pond. The bird was admirably stuffed by Waring Kidd, and solemnly installed in a conspicuous situation at Mr. Moline's residence at Godalming.*

* I may perhaps venture to add a note touching the boating on Old Pond, a pursuit, which, at the time the Letters of Rusticus were written, was much in vogue. The boating was not always without risk of accidents, as I can bear ample testimony.

$$
\begin{aligned}
& \text { Et quorum pars magna fui. } \\
& \text { quiperrima vidi, }
\end{aligned}
$$

We always selected the most windy days for a sail, because the more wind the more fun. One day early in March a tremendous east wind invited us to have a sail: it was one of those winds that seem to come through one's clothes as though it despised such slight impediments. For some time we went careering through the ripple at a spanking rate; the little craft bent beautifully to the breeze, the sails were skilfully handled, and the tacks made to perfection : but the spirit of mischief was afoot, and he who worked the mainsail had the temerity to make it fast: the rate increased and we were in full glee, when an irresistible gust capsized us in an instant: one moment we were calınly seated admiring our skill, and the very next we were scrambling for an awkward and precarious footing upon any part of the boat above water, our clothes drenched and the bitter east wind penetrating - as it seemed - to the very bones and marrow. To right the boat was impossible in such a gale; and to stand or sit in our drenched clothes perfectly unendurable: and how were we ever to get ashore! In this emergency, having first secured a rope, I jumped overboard and found I could touch the bottom, the water just coming up to my neck: cool, certainly, but warmer than the air. I began walking towards the nearest 
On this pond also has been killed the Hooper, or wild swan, whose grand trumpeting note I have heard while skaiting here by moonlight; and though I cannot say that in this sound there is anything in the way of a song, yet to me it is noble and pleasing. By the way, I would remark that I recollect nothing in Virgil, who is, and ever shall be, the poet of Nature, that leads me to suppose that he considered the swan a bird of song. I will give one or two passages which occur to me at this moment, which, if not very precisely quoted, will certainly convey the poet's meaning: -

Ceu quondum nivei liquida inter nubila cycni

Cùm sese è pastu referunt, et longa canoros

Dant per colla modos: sonat amnis, et Asia longè

Pulsa palus.

Nec quisquam æratas acies ex agmine tanto

Misceri putet, aëriam sed gurgite ab alto

Urgeri volucrum raucarum ad litora nubem.

Now, I grant the word 'canoros,' by a critic disposed to make swans sing, might be translated 'warbling,' ' melodious :' but its true meaning is 'loud,' 'shrill:' but supposing the swan-singers translate the word 'warbling,'. how in the name of fortune, will such a translation agree with

point of land; once or twice the water grew a few inches deeper, or perhaps only seemed to do so as a larger wave than usual passed by me, but soon it was regularly and gradually shallower, and then one of my two companions took to water and followed in my wake, and thus we walked with all imaginable composure to the shore. I have often thought it must have been a fine sight, had there been lookers on, to see us gradually growing taller and taller as the water grew shallower and shallower. When the capsized craft had drifted considerably towards the land, my other companion was rescued by a horseman who backed his steed into the water and took the shivering sailor up behind him.-E. N. 
'volucrum raucarum,'-_ raucus' meaning 'hoarse,' 'harsh,' 'jarring,' ' unpleasant?'

Again, Sir, in the following passage :-

Haud secìs atque alto in luco cùm fortè catervæ

Consedere avium; piscosove amne Padusæ

Dant sonitum rauci per stagna loquacia cycni.

The word 'rauci' appears again, and now actually as the descriptive adjective to the substantive 'cycni.' I recollect, however, one passage, which perhaps will be lugged in head and shoulders against me, if I do not first point out that it is nothing to the purpose. It is this :-

Namque ferunt luctu Cycnum Phaëthontis amati,

Populeas inter frondes umbramque sororum

Dum canit, et mœstum musâ solatur amorem.

Here Cycnus certainly sings, but 'Cycnus' is not a swan ; he is a youth who was turned into a swan, because he mourned when Jupiter capsized Phaëthon, and soused him in the $\mathrm{Po}_{0}$ and turned his sisters into poplar trees, as the sequel of the above quotation shows, and as is most ably set forth in the following beautiful lines of Ovid :-

Adfuit huic monstro proles Stheneleïa Cycnus,

Qui tibi materno quamvis à sanguine junctus,

Mcnte tamen, Phaëthon, proprior fuit. Ille, relicto

(Nam Ligurum populos, et magnas rexerat urbes)

Imperio, ripas virides, amnemque querelis

Eridanum implêrat, silvamque sororibus auctam :

Cùm vox est tenuata viro : canæque capillos

Dissimulant plumæ: collumque à pectore longum

Porrigitur, digitosque ligat junctura rubentes :

Penna latus vestit: tenet os sine acumine rostrum :

Fit nova Cycnus avis. Nec se cœloque, Jovique

Credit, ut injustè missi memor ignis ab illo.

Stagna petit, patulosque lacus: ignemque pcrosus,

Qux colat, elegit contraria flumina flammos. 
"The dull insipid truth" says Bewick " is very different from such amiable affecting fables, for the voice of the swan singly, is shrill, piercing and harsh, not unlike the sound of a clarionet when blown by a novice in music. It is, however, asserted by those who have heard the united and various voices of a numerous assemblage of them, that they produce a more harmonious effect, particularly when softened by the murmur of the waters."

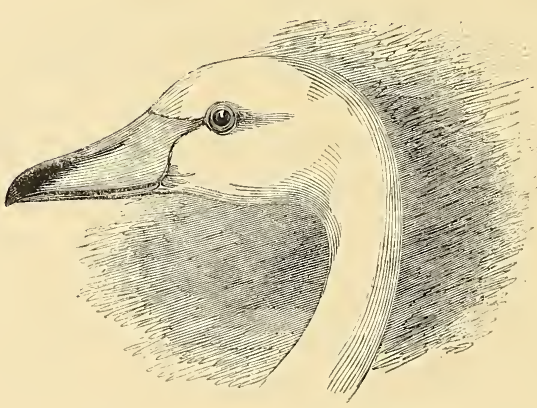

HEAD OF THE HOOPER. 


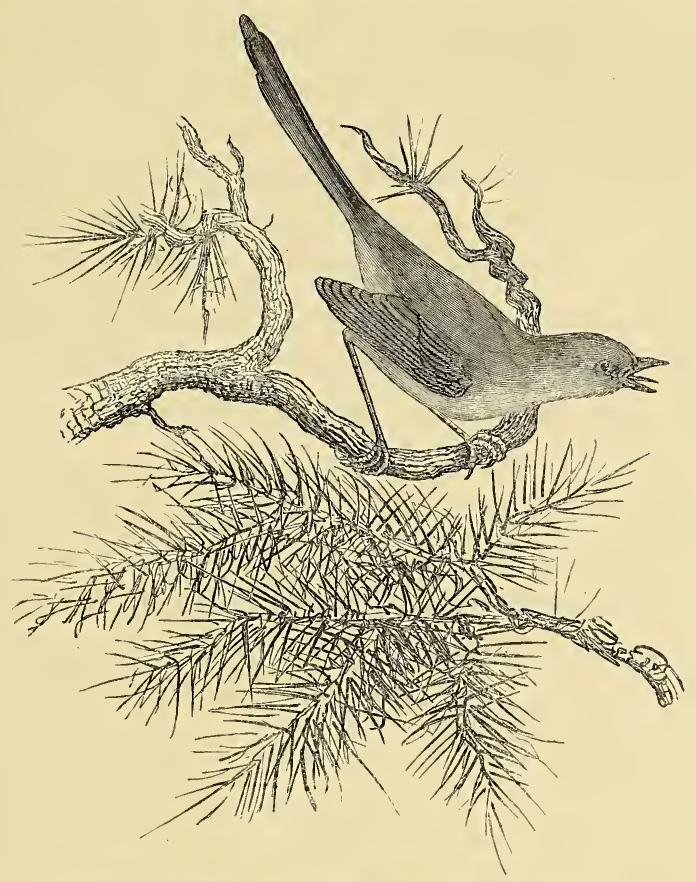

THE FURZE-WREN, OR DARTFORD WARBLER.

\section{CHAPTER III.}

The barren, wet, peaty district, called the Pudmoors, is the favourite resort of the FERN-OWL. In the daytime, while walking across the moor, you will every now and then put up one of these singular birds ; their flight is perfectly without noise, and seldom far at a time : but of an evening it is very different. About twenty minutes after sunset, the whole moor is ringing with their cry, and you see them wheeling round you in all directions. They look like spectres; and, often coming close over you, assume an unnatural appearance of size against a clear evening sky. 
I believe its very peculiar note is uttered sitting, and never on the wing. I have seen it on a turf-stack with its throat nearly touching the turf, and its tail elevated, and have heard it in this situation utter its call, which resembles the birr of the mole-cricket, an insect very abundant in this neighbourhood. I have almost been induced to think this noise serves as a decoy to the male mole-cricket, this being occasionally found in the craw of these birds when shot. Those who may not be acquainted with the cry of the bird or the insect, may imagine the noise of an auger boring oak, or any hard wood, continued, and not broken off, as is the noise of the auger, from the constant changing of the hands. The eggs of the fern-owl have frequently been brought me by boys : they are only two in number, greyish white, clouded and blotched with deeper shades of the same colour; the hen lays them on the soil, which is either peat, or a fine soft blue sand, in which she merely makes a slight concavity, but no nest whatever. The first cry of the fern-owl is the signal for the night-flying moths to appear on the wing, or rather, the signal for the entomologist's expecting them.**

The bird is plentiful on every heathy district in the neighbourhood. On Highdown heath Mr. Stafford shot forty-seven in a very short space of time.

* The fern owl grasps a braneh in a different way from other birds, the feet not being placed side by side on the branch-an arrangement which other birds adopt, and which places the body and braneh at right angles with each otherbut one before the other, so that the body of the bird is parallel with the branch. It is also to be remarked, that if the twig or bough is slightly aseending, this curious bird will almost invariably pereh with his tail upwards. I have no hesitation in saying that moths eonstitute its usual food, and these it swallows entirc and alive. I have known instances of their re-ascending the throat, erawling out of the mouth and escaping, after one of these birds bad been shot by moonlight. $-E, N$. 
We have a bird common here, which, I fancy, is almost unknown in other districts, for I have scarcely ever seen it in collections; and, from the few remarks about it and sketches of it in natural histories, no correct idea can be formed. I mean the Furze-wren, or, as authors are pleased to call it, the Dartford warbler. We learn that the epithet Dartford is derived from the little Kentish town of that name, and that it was given to the furze-wren because he was first noticed in that neighbourhood: the term 'warbler' is inappropriate, as the furze-wren is a poor warbler. If you have ever watched a common wren (a kitty wren we call her), you must have observed that she cocked her tail bolt upright, strained her little beak at right angles, and her throat in the same fashion, to make the most of her fizgig of a song, and kept on jumping and jerking and frisking about, for all the world as though she was worked by steam: well, that's more the character of the Dartford warbler, or, as we call it, the furze-wren. When the leaves are off the trees, and the chill winter winds have driven the summer birds to the olive gardens of Spain, or across the Straits, the furze-wren is in the height of his enjoyment. I have seen them by dozens skipping about the furze, lighting for a moment upon the very point of the sprigs, and instantly diving out of sight again, singing out their angry impatient ditty, for ever the same. Perched on the back of a good tall nag, and riding quietly along the outside, while the foxhounds have been drawing the furze-fields, I have often seen these birds come to the tops of the furze. They are, however, very hard to shoot; darting down directly they see the flash, or hear the cap crack, I don't know which. I have seen excellent shots miss them, while rabbit-shooting with beagles. They prefer those places where 
the furze is very thick, high, and difficult to get in. This bird breeds every year in the furze-bushes on Munsted, High-down, Headley, Elstead and many other heaths in our neighbourhood. And although it is so common in the winter, and so active and noisy when disturbed by dogs and guns, still, in the breeding-season, it is a shy skulking bird, hiding itself in thick places, much in the manner of the grasshopper lark, and seldom allowing one to hear the sound of its voice. And by the way, the furze-wren is not the only bird that breaks out into a kind of song when frightened or listurbed. I have often obtained a ditty from the sedge-bird by throwing a stone into a bush where I knew he was lurking: and even from the nightingale, by following him immediately after his arrival; his song, however, would consist only of two or three bars, preceded and followed by abundance of angry ' churrs.'

The Crossbill is by no means uncommon here in the winter. I have seen them of every hue, from bright yellow-green to bright red, and of all the intermediate shades between each of these and dull brown. Strange as it may seem, the light red ones seem to be young birds, the yellow-green ones old hens, and the brown ones old cocks; at least this has been the case in those which I have had an opportumity of examining.* The cry of the crossbill is very peculiar; it is sharper than that of the greenfinch, and louder than that of the linnet. I may however observe,

* All the observations made on the changes of plumage in these singular birds have been without a satisfactory result. Mr. Henry Doubleday, whom I consider the best observer of our British birds, says, "I can say but little about the colour of plumage of crossbills as depending on age: they all turn yellow in confinement, and $I$ have shot at the same time both red and yellow birds, apparently old, and others of mixed red and yellow : after the first moult the young males secm to be a reddish buff." $-E$. $N$. 
that generally while perched they are silent and very quiet birds, a number of them sitting in a Scotch pine, and remaining in it even a whole day, if not disturbed ; at any rate, till every cone had been pried into, and the seeds taken out. They do not take the cone off ; it may, perhaps, sometimes fall while being robbed, from over-ripeness. The holding of a cone in their claw, and extracting the seeds with their beak, I have never witnessed.* After finishing the produce of one tree, they fly off in a jerking chuckling train, to some other. On the wing they always chuckle, as though talking, and, on settling again, give one or two loud notes, as the chaffinch does, as if to announce his arrival.

The Siskin is always a regular winter visiter with us, keeping company with the Lesser Redpolls, which abound wherever there are alders along the banks of the Wey : they feed almost entirely on the seeds of the alder, and whilst intent on picking them out of the little catkinlike cones, both these birds are so tame and fearless, that you may pass under the tree without alarming them. I have often been near enough to touch them with a longish stick if $I$ had felt inclined. While intent on getting at the seed, which is no very easy task, they turn and twist about in all directions, often imitating the tits in the variety of their attitudes and strangeness of their contortions: Bewick's marsh tit, with its back downwards and its head slewed round on its shoulder gives a very good idea of the position of a redpoll or a siskin when prying into the pendent cones of the alder. They arrive about the beginning of October in large flocks, consisting almost entirely of

* Mr. Henry Doubleday has observed this act in some crossbills in confinement.-E. N. 
females, at least in the proportion of fifty or sixty to one; in this respect resembling the chaffinch, so aptly and beautifully named by Linnæus 'cœlebs,' or the bachelor; immense flocks of the females migrating, and leaving their mates during the winter.

And by the way, this said Chaffinch, or Pink as he is often called, is a prime favourite of mine, and though he is certainly guilty of some indiscretion in pulling up young radishes and leaving their white stalks strewed on the ground, yet that were a hard-hearted gardener who would not forgive him this failing in consideration of the good service he afterwards performs when the apple and pear leaves are woven together by the grubs of a little worthless moth, and so smothered and choked, that the crop is sure to fail if there are neither pinks nor titmice to abate the nuisance. It is then that the pirk appears in his most amiable character: it is then that his bride is sitting on her pattern of a nest, the neatest and most compact of all nests, and he spends all his time in routing out the grubs from the web-joined leaves, and bearing them to his lady love, or perhaps to the nestlings who have just burst the shell, and are yet too tender to be abandoned by their mother. The saucy bluecap himself is not more expert in this grub-hunting, nor can he cheer us, as does the pink, with a sweet and merry song. I must, however, confess, that that same song, cheerful and merry and sweet though it be, often comes too soon, long, long before the sun has power to warm us, and then sounds rather tantalizing, the semblance without the reality of spring.

The BLACKCAP is abundant with us: it comes on the 13th of April, and stays and sings all the summer through. Nothing ever delights me more than the song of this bird. 
He has decidedly more compass and variety than any other English bird except the nightingale: he begins with a soft low melodious whistle, like the voice of the nightingale heard afar off, or the whistle of a countryman at a distance, softened into melody by the surrounding hills; it comes nearer and nearer, louder and louder, a series of varied, rich, liquid, and sonorous notes, till all at once you are astonished to find the little bird, from whose throat such surpassing melody is poured, is sitting in a bush by your side, or on the branch of a tree close over your head. But notwithstanding all the wildness and variety of the blackcap's song, there is a vast deal of method in it. It is quite worth while to listen attentively to him, and you find that his usual song is very tune-like, and might readily be imitated on the flute or flageolet. Sometimes, after he has gone through his tune several times in succession, he will introduce a few notes as from a march, and then all at once he will give you a delicious and off-hand imitation of the song-thrush, blackbird, or even nightingale.

The Nightingale accompanies the blackcap, or perhaps precedes it by a single day. I have seen or heard it on the 12th of April for many following years. The neighbourhood of Godalming has been called the valley of nightingales, and well it deserves the name: throughout the fine nights in May, there is a complete chorus of these birds; every coppice contains numbers, and every garden two or three pairs: it is really glorious to listen to them in a moonlight midnight, after a showery day. There is a stile under Ockford coppice, at the back of the town, on which I have sat for hours, listening to the hundred-tongued harmony, interrupted now and then by the sharp cry of the screech owl, as on noiseless wing he wound his way along 
the meadows, mouse-hunting, or the harsh chatter of the sedge-bird, or the craik, craik, of the daker calling to his mate. The song of the nightingale has been a favourite theme with poets in all ages, and none of them have exaggerated its sweetness or its variety. Every year, directly the nightingales arrive, we have the London bird-catchers down here with their traps and mealworms, and a great proportion of the earliest arrivals are conveyed to town. In the time of Virgil they used to take the nestlings :-

\section{Qualis populeâ mœrens Philomela sub umbrâ \\ Amissos queritur fœtus, quos durus arator \\ Observans nido implumes, detraxit;}

but with us the bird-catchers only care for the old birds, and it is really wonderful how soon they manage to subdue all the untameableness which wild birds first exhibit. It is quite a science to break the spirit of these children of Nature, to bring them into artificial habits, to box them up in darkened cages and to feed them with strange food, and what is still more astonishing, to make them sing quite as well as in a state of freedom.

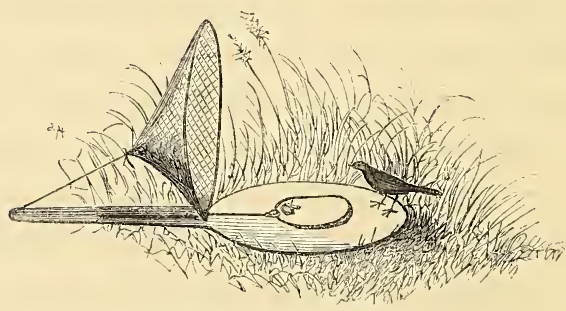

THE NIGHTINGALE-TRAP. 


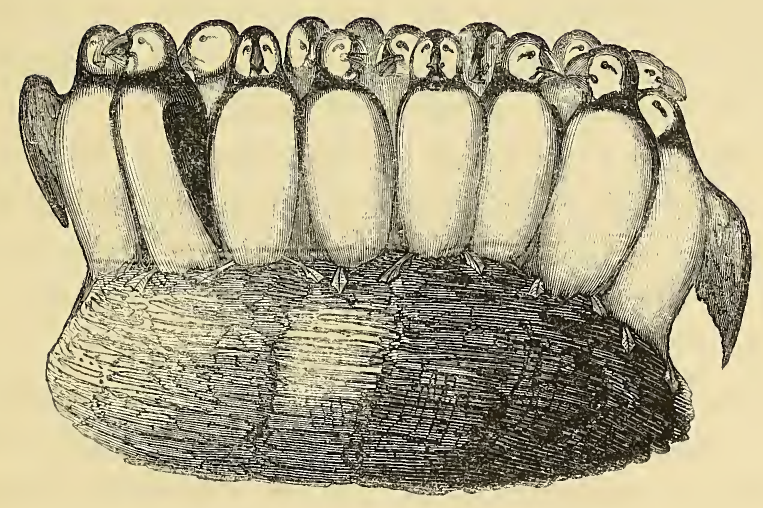

A COMPANY OF PUFFINS.

\section{CHAPTER IV.}

ON a fine morning, towards the end of May, three of us mounted the Rocket Portsmouth coach; double-barrelled patent percussions having been previously duly prepared, and a suitable supply of copper caps, powder and shot, and the etceteras of bird-stuffing laid in; and the close of day found us at Newport, in the centre of the Isle of Wight. The next morning we reached Freshwater, or Freshwater Gate, as the natives term it, experiencing a most sanguinary feeling against all manner of sea-fowl and ornithological rarities : we, however, soon learned that we must reserve our ardour until the following morning, for that the birds went to.seaward at sunrise, and did not return until it was too dark at night to get any shooting; so we 
wandered about the neighbourhood all day, and shot a stray summer snipe or two, and two or three old crows.

At Freshwater Gate there is but one inn, and, unfortunately, its 'all' of beds was occupied; however, there is a little square building belonging to the same establishment, but disconnected, and situated farther down the beach; and in this the accommodating landlady made up three beds: here, after making an agreement with two fishermen for the services of themselves and their boat at three o'clock the next morning, we turned in for the night, - the chambermaid fastening the door outside with a wooden button, to keep us from harm: other fastening there was none. It may be supposed we did not sleep very soundly; the incessant roar of the sea, as its waves broke on the shingly beach, and approached within a few yards of where we lay ; the odd fastening of our apartment; tales of smugglers and pirates, which we had been listening to ; and the anticipation of a novel and exciting sport, furnished us amply with amusement and talking materials, until, at half-past two, one of the fishermen unbuttoned our door, and expressed himself at our service.

We were soon ancle-deep on a beach, over which a long swell was alternately forcing forwards a multitude of pebbles, or drawing them with it as it retired towards the ocean, and producing an incessant and monotonous rattle, none the more pleasing to our ears, that we had been compelled to listen to it for the last five hours. The night air still blew cold and clammy from over the expanse of waters; and though the first blush of morning was visible to landward, over the sea all was gloom. The fishermen pushed off the boat, and in a minute they were steadily labouring against a heavy swell and a rising tide; we 
were alternately lost in the hollows, or mounted on the crests of the swell. After an hour's hard pulling, in which two of us occasionally joined, we found ourselves under the highest point of the cliff. The spot is marked by a red streak, which commences at the velvet turf at the summit, and is distinctly traceable down to the water's edge. The height of the cliff is 615 feet; its face is nearly perpendicular; yet, notwithstanding this, the samphire-gatherers and the egg-collectors scale by means of ropes nearly its whole surface.

The men pointed out to us a king's cutter in chase of a smuggler: they were so far out to sea as to have escaped our notice altogether. The smuggler was a small dandyrigged fore-and-aft craft, of about fifty tons, her canvas brown as though tanned. The cutter was twice the tonnage at least, with a tremendous mainsail, foresail, jib, flying-jib and gaff-topsail, all as white as snow, and now bright with the first light of morning. The fishermen told us the smuggler had most likely landed her cargo at Hurst Castle in the night, as she never would have been hovering about the coast after daybreak with anything on board. 'The sight was one of great interest to ourselves as well as our companions, who were completely engrossed with it, and loudly expressed their pleasure when they saw that the cutter, spite of her superiority in canvas, was dropping astern, and the distance between the two consequently increasing. A puff of white smoke issued from the bow of the cutter, it passed along the deck, and was speedily far behind: the chase was hopeless; the cutter tacked; and the report, reaching the shore, echoed among the rocks like distant thunder.

While engrossed in this animated chase, we had reached 
the region of birds. Between the highest part and Sun Corner the cliff is more than perpendicular, it positively overhangs: here, then, is the retreat of innumerable sea-birds; here the foot of man has never trodden; here patent percussions were of no avail. The inmates were already on the move : guillemots and razor-bills, in parties of tens, twenties, and thirties, were continually dropping from their stations, and whirling on rapid wing towards the ocean; the great burgomasters, far, far above the summit, were wheeling round and round, like eagles, and uttering continually their sonorous and piercing call; while in the distance the smaller herring-gulls were collecting by hundreds about the Needles. The fishermen now pulled us right in for the cliff; and, as we approached, what a sight did we witness! Every inch of projecting rock was occupied : there were hundreds, thousands, millions of birds. I should premise, that throughout the surface of the cliff are excavated ledges, which are caused by layers of a softer substance intervening, that has crumbled, perhaps partly with frost, and partly with the operations of the tenants : these softer strata are perforated like honeycombs by the puffins. Along these ledges the birds were crowded so thickly, as positively to push the foremost ones off by the pressure from behind, as fresh troops issued from their holes: these would fly a little way, and, returning, settle on the heads of others, and thus, by slipping in, find themselves a footing, the foremost birds being obliged to tumble off, as these intruders had previously done. Some ledges were occupied solely by puffins, whose conspicuous bills, and squat though upright position, rendered them instantly distinguishable. The little fellows turned their heads sharply on their shoulders, first on one side, then on 
the other, like people holding an animated conversation. They have white cheeks, with a black hood, which seems fastened under the chin with a band of the same colour. A few of the delicately white kittiwakes* were perched here and there on a projecting crag; and, scattered at regular intervals, like stern, upright, solitary sentinels, stood the corvorants, spotting with black the whole surface of the cliff. There seemed little disposition on the part of any one species to consort with another : though crowded together on the cliff, yet each species kept in degree separate : willock crowded willock; puffin, puffin. A noise, as one might suppose like that of disembodied spirits in purgatory, issued from every part of the rock; whether it proceeded from the razor-bills, willocks or gulls, we could not make out; but, of all the horrid and piteous groanings I have ever heard, these were the most so. Perhaps it was only a morning hymn of thankfulness and happiness; perhaps the soft note of love; perhaps the united cry of thousands of the young for food. Being sufficiently near to see very clearly the whole mass of living creatures before us, the fishermen suggested that a single barrel should be fired at random, at the same time they both gave a tremendous shout. Words cannot describe the scene that followed: corvorants, ravens, gulls, kittiwakes, puffins, razor-bills, guillemots, all left their stations ; the very surface of the cliff came towards us. The remaining barrels were soon emptied, and all was one wild uproar : the sky was positively darkened; the air filled with heterogeneous sounds : the screams, the calls, the groans of the birds;--

* Mr. Yarrell informs us (Brit. Birds, iii. 446) that this bird breeds in these cliffs every year, in great numbers, but $I$ am inclined to think this is not the case; the bird to which he alludes is probably the herring-gull--E. N. 
the continued ringing of the fishermen's shouts; - the almost everlasting echo of our guns, which every crag and cranny seemed determined to reiterate; - and, above all, and harmonizing all, the tumultuous roar of the restless ocean, as its long and heavy swell dashed against the perpendicular but rugged cliff; - produced such a combination of sights and sounds, as, once seen and heard, can never be forgotten.

But where was the produce of our united discharge? Twenty or thirty birds, at least, ought to have fallen plump into the sea; for we fired right in their faces, and some of them seemed to be within ten yards of us : however, not a bird fell, nor did there appear to be a single feather touched. We stood gaping at one another in unfeigned astonishment. Was the miss to be attributed to the rolling of the boat, or the swell? Certainly not; for in such a crowd all nicety of aim would have been useless. Had we forgotten to put in the shot? Still very improbable. The fishermen explained the mystery; and I doubt not your ornithological readers have done the same: the feathers on the breasts and necks of sea-birds are so closely matted together, and form a covering so smooth and compact, that shots striking in front will not enter, but instantly glance off, without doing the slightest injury. As soon as we understood our error we were determined to rectify it, and were loading again in an instant. Now, as each little covey (for they fly in coveys, like partridges) passed over us, we took them in the rear, and to every barrel a bird fell thud into the water. This plan answered delightfully; and finding its efficacy, our spirits, which were somewhat damped by the first disappointment, now rose with the excitement of the scene; and although, partly owing to the motion 
of the boat, our shots were not invariably successful, yet we soon managed to cover the greater part of the bottom of the boat with the slain.

The birds, after the first rush, soon diminished in numbers, and in about an hour became so thin as scarcely to afford us the chance of a shot; so we proceeded on our way past Sun Corner, and found that between this point and the Needles a whole colony of corvorants had established themselves: the old hens were visible by dozens sitting upon their nests. Precisely under the spot where the corvorants were sitting was a narrow slip of beach. On this we landed with great difficulty, as the swell of the sea continued very heavy, and the bottom is here very bad; and, being almost perpendicularly under the birds, we could plainly see their long necks and stiff still heads poked out to seaward : so we spent much time, swan-shot, bullets, and excellent powder; and finding that they did not move their heads one inch to the right or left, we got into our boat, and floated onward with the tide towards the Needles; resolving, however, to try the effect of shots from above, as it was very clear they took no effect from below. To accomplish this, we had to pass through the Needles, and land in Alum Bay, whence there is a decent foot-path up the cliff, and across to the top of that other cliff, on the ledges of which the old hen corvorants were so sedately planning for the welfare of their future progeny; in fact, where they were reckoning their chickens before they were hatched. The water had gone down about three hours, and the passage through the Needles was a ticklish affair. The gap which we were about to attempt was little wider than our boat, and had a constant current running rapidly at ebb tide towards Alum Bay. The depth varied as each 
successive swell rolled in from the ocean, from 1 foot to 20 feet, and at low water was left quite dry. Two of us knew something of old ocean and old ocean's ways; and though we were ignorant of this particular spot, we learned sufficient from the fishermen to know the thing was to be done. Off went the coats; two men to each oar: we held our craft steadily against the current, which was tremendously strong, and kept her head right for the opening. An enormous swell rolled seaward, leaving us almost aground: rattle, rattle, and thump, thump, we heard the stones and fragments of rock beneath us ; it seemed an hour running out: at last another came: "Here she comes again! keep her head right, and stand by!"-up, up, we rose. "One stroke, up oars, let her drive!" - and through we went, in gallant style, on the very crest of the swell.

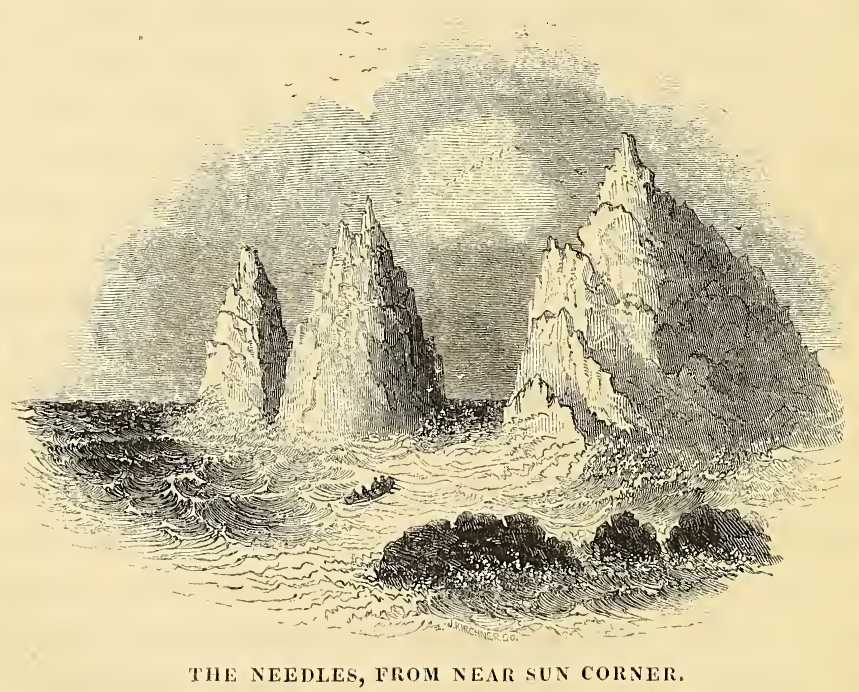




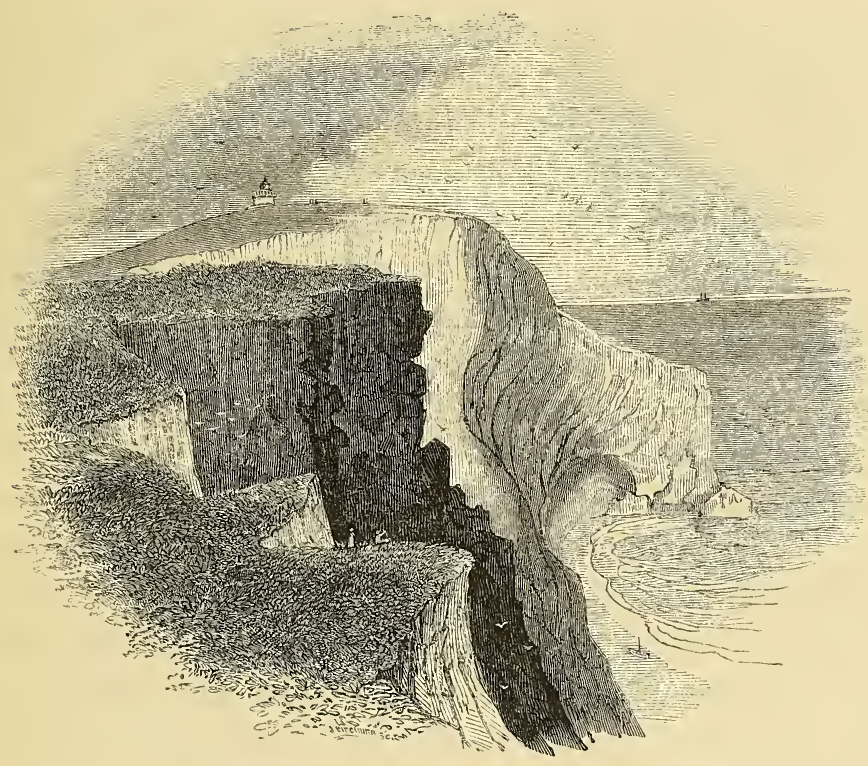

SUN CORNER, FROM NEAR THE NEEDLES.

\section{CHAPTER V.}

ON the Alum-Bay side of the Needles there was no swell to be felt; but the meeting of opposing tides and currents, the influence of the winds, and the rough rocky bottom keep the water in a sort of perpetual boil. As we approached the shore, we had to pass over a good many lobster-pots, which we took the liberty of examining, and found, among other contents, a great many soldier crabs, which had established themselves in the shells of the common whelks: we did not rob the poor people of their lobsters, but carried off the soldiers and a few species of crabs which could only be useful to a naturalist. The Geology of Alum Bay must be very interesting; the cliff above it 
presents all the colours inaginable. The poor people in the neighbourhood get sands from it of a dozen different colours; and, running them into a phial, make each colour form a distinct ring, which has a very pretty effect: these phials, so filled, they sell for a shilling each.

We ascended the cliff, examined the lighthouse, purchased a variety of eggs, and crossed the hill to the corvorant colony : then, by lying down on our bellies on the turf, we quietly peeped over the edge of the cliff, and obtained an excellent view of the amiable company, from which a stench arose almost enough to suffocate us. There were young ones of all sizes, - some almost ready to fly, some only covered with down; some nests had one or two eggs, which are very small in proportion to the size of the bird, and of a dirty white colour: many hens were sitting, and here and there a solitary old cock (the crested corvorant of Bewick) was perched on his triple support of tail and feet, contemplating the expanse of ocean as motionless as a statue. One of the party now determined on the hazardous experiment of leaning over the cliff and shooting them as they sat; the other two remonstrated, but to no purpose: so a line was formed; the first held tight the coat-tails of the shooter, the others locked hand in hand; thus making a dead weight of four against one, in case of any propensity on the part of the first to lose his balance. Thus arranged, the adventurer shouldered his double-barrelled, and, actually bending over the cliff, he pulled the trigger. An old corvorant fell five hundred feet down the cliff, upon the little narrow beach before mentioned; another trigger was pulled, and down went another corvorant. The shooter then exchanged guns with him who held him by the coat-tails, and with each barrel of this he also sent 
a corvorant to the bottom; so there were four, as we supposed, quietly waiting our return. Emboldened by this success, we proceeded more than a mile along the top of the cliff, continually peeping over. We discovered two nests of a gull (perhaps the herring-gull), each with three eggs, of an olive-brown colour, with darker spots: the nests are made of dried grass and fern. The fishermen told us that these gulls will lay three eggs again, if the first three are taken, and three more when the second three are taken, but no more than this, nine being the whole stock for one year. But the greatest curiosity we observed was the nestless and solitary egg of the guillemot, balanced, as if by a geometrician, on the bare rock, and looking as though the least puff of wind would blow it off its station into the sea.* We learned from the fishermen, and some boys of the neighbourhood, that the puffins never expose their eggs, like the corvorants, razor-bills, guillemots and gulls, but lay them at the end of long holes, which they hollow out of the softer parts of the rock. We bought a few of these eggs to bring home; they were dirty white, with darker spots.

Along the circuitous edge of this cliff the egg-collectors plant the iron crow-bars for attaching the ropes by means of which they descend. Two ropes are commonly used, one goes round the body, and the other is held in the

* "The rock-climbers assure you that the guillemot, when undisturbed, never lays more than one egg; but that, if it be taken away, she will lay another; and, if she be plundered of that, she will then produce a third; and so on. If you dissect a guillemot, you will find a knot of eggs within her. The rock-climbers affirm that the bird can retain these eggs, or produce them, according to circumstances. Thus, if she be allowed to hatch her first egg, she lays no more for the season; if that egg be lost or taken away, another is laid to supply its place."-Waterton's 'Essays on Natural History,' 1st Series, 158.-E. N. 
hand: the first is warped round the crow-bar, so as to be let out at pleasure; the second is fixed to it by a noose, and when the suspended sportsman wishes to reascend, he shakes this second rope as a signal, and two men on the top of the cliff begin hauling at the first, or waist-rope, while he assists the operation by climbing up the second, hand over hand. The crow-bar is rarely stuck so deep as eight inches in the ground, so that at every movement of the collector it may be seen to give most fearfully; but impunity creates valour, and as no ill has yet resulted from this careless mode of planting the bar, they seem to fear none. At some parts of the face of the cliff are shelving ledges of the most slippery turf, and when arrived at these, the collector throws off his waist-rope, and walks or clambers along for fifty or a hundred feet, and sometimes even more. This, though less striking to a stranger than the act of dangling from a rope, after the fashion of a spider from his thread, is in fact the most dangerous feat of all, for the slightest slip is fatal. Another constant source of danger is the detaching of small pieces of rock or loose stones, by the friction of the rope against the cliff: to avoid these, the cliff-man has to keep an incessant lookout, and to bob his head this way and that, to escape a broken sconce.

The Guillemot, or 'willock,' as it is here called, sits with its egg under its wing, or pressed to one side of its breast, and always on the same side, so that a mark on the breast of the bird plainly shows the situation of the egg whilst she is sitting.* After the day when the egg is laid,

* "The men also assure you that, when the young guillemot gets to a certain size, it manages to climb upon the back of the old bird, which conveys it down to the ocean. Having carried a good telescope with me, through it I saw num- 
it is very rarely left, and it is only for this one day that the collectors have much chance of getting it. They tell you that when the bird has once begun sitting, she will never suffer herself to be robbed, but that when all chance of saving the egg is gone, she rolls it off the ledge and flies away. This story is partly true, but there is some doubt whether she acts on the true dog-in-the-manger system of smashing her egg because no one else shall have it: its position is so ticklish, that when the bird is forced to take flight to avoid capture, she may very easily upset her charge and pitch it over the precipice, in the mere flurry attendant on the act of self-preservation.

Man is not the only robber this poor bird has to fear: the gulls and ravens are ever on the alert to secure her eggs. This is horrid unkind of neighbours, but perhaps not inconsistent with our own practice. The GulLs are for ever scanning the face of the cliff, hoping to catch a glimpse of an unprotected egg. Directly a gull has found one, he charges point blank at its small end, using his beak as a lance : the huge egg, thus pierced, sticks on his beak, and he flies away as though he was carrying a great pear in front of his head; in this way he sucks out all the goodness while on the wing, and drops the shell when empty. These shells, with a great hole at one end, may

bers of young guillemots, diving and sporting on the sea, quite unable to fly ; and I observed others on the ledges of the rocks, as I went down among them, in such situations that, had they attempted to fall into the waves beneath, they would have been killed by striking against the projecting points of the intervening sharp and rugged rocks : whercfore I concluded that the information of the rock-climbers was to be depended upon; and I more easily gave credit to it, because I myself have seen an old swan sailing on the water with her young ones upon her back, about a week after they had been hatched." - Waterton's Essays, 1st Series, 159.-- E. N. 
often be found upon the downs above, and naturalists profoundly assert that stoats and weasels are the aggressors : thus assigning to those lithesome quadrupeds a marvellous extent of cliff-scaling capability.

The Raven has no less taste for willock's eggs than the gull, but his manœuvres are somewhat different: he never pierces the egg, but seizes it suddenly and darts off to the top of the cliff, amid the uproar of the colony. While on the look-out, he traverses silently and slowly the face of the cliff, making little circles, and returning again and again to the same hunting-ground, but the moment he spies an unprotected egg, he darts in, seizes it-I suppose with his feet, and makes off like an arrow to the summit, there to enjoy his meal at leisure. You may mark him down, and then by vociferous shouting and running to the place, make him leave his booty, which is always sound and whole.

The Peregrine Falcon has had her eyrie here from time immemorial : and these noble birds are often to be seen soaring about the cliff, the terror of jackdaws, whose young at this season constitute their favourite prey, or perhaps the favourite food of their own young. The fishermen told me that this falcon always breeds here, and that it is constantly following the kestrels,* which abound all along the cliff, as if to drive them away from his territory.

* "The parent birds are now well nigh considered sacred; or rather, if the truth must be told, it has been found more gainful to preserve than to destroy them ; seeing that the young birds bring in half-a-guinea each to the fortunate possessor of the nest. It is unquestionably true, that if one of the old birds be destroyed, the survivor will find another mate, and return at the period of incubation to the wonted locality. Of the pair frequenting the Freshwater cliffs, what particulars I am enabled to give, were learned from one of the cliffmen, named Jackman. When I made his acquaintance, in the autumn of 1839, he told 
After having satisfied our curiosity here, we returned to our boat, and crossing Alum Bay we again passed through the Needles, and pulled in for the beach at Sun Corner, where the corvorants had fallen. Three were quite dead, the fourth had got into the water and was swimming about in style. We chased him more than an hour, firing at him about forty times, but to no purpose, as he dived the instant the trigger was pulled : at last we very reluctantly gave up the pursuit as hopeless, the wind having freshened, and made the swell rather too heavy for an open boat; the tide, too, was quite out, and the rocky bottom occasionally peeped up all round us in the hollows of the sea, looking very black and disagreeable. Two of us took a spell at the oar, by turns, with the fishermen, and worked away like Britons, till a noble swell laid us high and dry on the shingles at Freshwater.

The following day was spent in a repetition of the cruise under the cliff, with pretty much the same success; and the next morning we started on foot for the southerly point of the island. The wind had been sinking during the whole of the previous day and night, and what air now

me that for fourteen years successively he had robbed these birds of their young. He had never known more than one pair to frequent that neighbourhood; yet though robber every year, they have never left it. They build no nest, but deposit their eggs, four at most, on a ledge of the cliff, always the most inaccessible; never however a second time on the same spot, but seldom more than a hundred yards from the spot selected by them on the preceding year. The young are hatched about the first week in May, and the parent birds make ample provision for their wants. From ten to twenty yards from the eyrie is found a store well supplied, consisting usually of puffins, young jackdaws - their 'daintiest bits' according to Jackman, and kestrels ; of which latter birds, surprising as it appears, Jackman assured me he has found greater numbers than of any other bird, except the puffin." - Rev. C. A. Bury, in the 'Zoologist,' i. 517. - E. N 
remained blew light as zephyr off shore. The sea was without a ripple; and the chalk cliffs, the two rocks in the bay, and the distant St. Catherine's; were mirrored on the bosom of the ocean so completely, that every straggling sheep, browsing the turf above the cliffs, was as distinctly to be seen in the reflection as the reality. I shall never forget the quiet beauty of the scene: - there was nothing wild or grand in nature; nothing wonderful in art; there was neither church, house, tree, nor shrub, nor aught to excite the beholder to exclamation; - quiet sea - unromantic, unvariegated, perpendicular, white cliff - monotonous downs. Nature seemed to be at rest; man seemed to be a stranger; he was no where disturbing her repose; he had no where distorted her figure; - the distant tower of St. Catherine's was the only visible proof that he had existed.

The tide being out, we walked below the cliff, and amused ourselves with the vagaries of the little crabs, which, like the generality of mankind, appear to be looking one way while they go another; the smooth sand was curiously mapped out by the infinity of their tracks. We established a crab-race; and gallantly did the little urchins perform. A little direction was required now and then to keep them from bolting off the course; but in the main they behaved very well, and temperately; and their sideling gait had the air of circumspection and calculation. You smile, good Sir, at our childishness ; - you are welcome. We laughed outright. Under the sea-wrack were shoals of that little jumping shrimp* with a large head, which is found on nearly every coast. On lifting up a 
handful of sea-wrack, they swarmed and leaped about like fleas - some of them being scarcely bigger. These little fellows are the best anatomists in the world: in a single night they will turn a small animal into a more beautifully white, and clean, and perfect skeleton, than can be obtained by any other means. They are of all sizes, from half an inch long to no size at all.

Our double-barrels had been lying idle in the hollow of our arms for some hours, when a flock of RING-DOTTERELS and Purres started up before us, and, taking a circuit over the sea, settled again, farther on, at the very edge of the rising tide: here they boldly ran into the water for any floating food they might spy, sometimes allowing each little swell to take them almost off their legs. We put them up again and again, and succeeded in bringing down three of them; but they always fell in the sea, and were lost to us. At last, they altered their minds, and, instead of going ow way any farther, took a wider sweep over the sea, and settled behind us. One bird, which it was our particular object to obtain in this journey, we did not even get a glimpse of, - the red-legged crow. We had been told by an ornithologist of great accuracy, that it breeds in several parts of the cliffs every year; but of this there seems to be great doubt; - its chief resort appears to be the Cornish coast.*

Near Black-Gang Chine I had the good fortune to meet with an insect I never saw before or since. The soil was a kind of loose sand, with a good many short blades of

* Mr. Hutchinson has just informed me that a pair of the Cornish choughs still frequent the neighbourhood of Freshwater. They have frequently been shot at, and one, which he saw repeatedly, appeared to have had its leg broken. On the opposite coast of Hampshire these birds occur not unfrequently.-E. N. 
withered grass sticking up out of it, the runners of which crawled along the top, or just below the top, as the case might be, now and then shooting down a root to hold fast by; and looking altogether something as though an old tanned fishing-net had been thrown over the soil to keep it from blowing away, and had shot out and taken root at the knots, just for its own amusement, or as a hold, in case the sea-breezes should be too much for it. In this place, stopping to pick up a feather, I saw something move in the sand, but as soon as I could fix my eye on it, all was still, and I could only find a little hole, as round as though some one had stuck a common lead pencil into the sand and taken it out again. There was a neat and perfect roundness in the hole, which told me at once it was a tenement of some kind; and sundry cases of beetles, legs of gnats, and dried dew-moths, scattered round it, signified, moreover, that it was inhabited by some sort of inhuman Polyphemus. I was soon down on my knees, and had my knife out ready for digging, when, within a foot of the first, I saw another stir - and another round hole instantly appeared. It now occurred to me that I might, with quietness and patience, get a sight of one of these hermits while he was sunning himself: I therefore lay as still as a cat watching at a mouse-hole, and was soon rewarded by seeing the gentleman make his appearance almost close under my nose. Unluckily, like Alexander, I had placed myself between the sun and my Diogenes, and this seemed to make him very fidgetty and uneasy, so I obliged him by moving quietly out of the way, and letting the sun shine on him, by the same movement bringing my eye within about fifteen inches of him. Nothing appeared but a broad flat head, which fitted very accurately the mouth of the hole, and 
which was furnished with bright shining eyes, and a pair of homible jaws, held wide apart: these shears had doubtless cut the thread of existence for many a poor wanderer, whose luckless star had led him to the abode of this child of Erebus.

I cut off the gentleman's retreat by passing a stick into the sand sideways, so as to cross his burrow, and then with a bit of a jerk unearthed him and laid him sprawling. $O$, such a beauty! the Parcæ, sweet creatures, the Eumenides, gentle turtle-doves, were lovely in comparison : I'll describe the animal, with an eye to entomological science. Aspect, vicious : temper, ferocious : jaws, stuck on the wrong way, like a figure-head shipped looking aft : head, big: back, humped, the hump adorned with two hooks. When first unearthed, he was monstrous sulky, and lay twisted in a kind of half-kink, for all the world like a pot-hook: but he soon found the inconvenience of this, and set to work to make another hole, for which he used his feet and jaws, loosening the sand with his feet, and fetching it out with his jaws; in this way he got down about half an inch, and then adroitly hanging himself to the edge of the hole by the hook in his back, he continued his labours in this droll position : at last he got quite out of sight, and as he did not come up again, I concluded he was taking a nap after his labour, and so I would not again disturb him.

This ugly grub, as my friend tells me, is the larva of Cicindela campestris, a beautiful green beetle, which is common in all sandy places in the summer, and pursues the whole insect race with unceasing ferocity. The gentleman runs and flies so fast as to puzzle the hunter, and, most commonly, to get away from him; and when you do 
get hold of him, he fights, and bites, and struggles, to the last. _ told me of another larva, which he said he had met with near Marseilles, called the 'Fourmilion,' or 'ant-lion;' whose operations, if you will have them as an episode, may be thus set forth.

A loose light sand is the favourite soil of the AnT-Lion. In this he makes his snare, and passes the first part of his life. His snare is a round hole, about two inches wide at top, and with sloping sides, gradually lessening to a point at the bottom, where the tenant lays in wait, his jaws only being visible, and the rest of his body hidden beneath the sand. The sides of this trap are made of the finest and driest sand, which, when an insect of any kind alights on, gives way beneath its feet, and so conducts it, in the most perfectly natural manner, into the very jaws of its devourer. It sometimes happens, that a shower has made the sand more solid, and better footing than when quite loose; and then the luckless mortal, who has inadvertently dropped or flown into the hole, begins to remount the side with ease and fancied safety; but, alas, the safety is only fancied! Mark the deepness of the rogue in hiding: he dips his jaws into the sand, and, being a capital marksman, jerks it, with certain aim, on the back of the intruder, not once only, but again, and again, and again; and thus keeps up such a constant and well-directed fire, that the poor creature is at last tired out, and slides into the power of its enemy. The ant-lion is about the size of a large garden spider, and something like it in shape; after it has fed for five weeks on all the stragglers that were unfortunate enough to get in its way, it spins itself a white silky covering, and changes to a chrysalis, and afterwards to a beautiful lace-winged fly, which emerges from the sand like a spirit escaping from the tomb. 
It was night before the three weary travellers reached Sand-rock Hotel, beauteous place! - Undercliff, never to be forgotten; - when first I saw thy bewitching face, the full moon was riding triumphantly over the ocean, silvering the multitudinous ripples with her reflected image, and making a broad and glorious track of ever-varying light - and thou wast bathed in more than ordinary splendour by the brightness of her beams! After roughing it on the ocean, and among the cliffs of Freshwater and the Needles, the quietude and luxury of this spot seemed to invite repose; we tarried there many days; and then, walking through Appeldurcombe and Newport, arrived at Cowes; - and there, taking ship, sailed to Portsmouth, and so returned.

I don't know how it is, but little trips - like this of ours to the island-are of much greater worth than at first they would appear: there is not only the gloss of newness on all that we see and hear, but there is 'mind-food' for a long time to come. We ascertain certain facts that make us thirst for more facts : we get hold of fragments of histories so interesting that we want whole histories. For instance, we find from the inhabitants of the Isle of Wight, that the puffin comes and goes with the swallow; but we fairly inquire, from whence does he come,--whither does he go? My authorities, White and Bewick, say nothing on the subject. White, as far as I recollect, does not mention the puffin : and Bewick tells us that they 'assemble' early in April; a most vague and unsatisfactory announcement, when implying the arrival of a bird of passage. I have good authority for asserting that in the winter the puffin is found on the western coast of Africa; and I find that in Italy, and indeed in the Mediterranean generally, it is a 
rare and almost unknown bird. I therefore conclude, that its autumnal course is along the western coasts of France, Spain and Africa.

Then when one takes a dead puffin in hand, there is a great deal to admire in his build. I learned from the fishermen, that they very often catch puffins in their nets, and in deep water too, so that we have strong evidence that Mr. Puffin pursues his prey under water: now if we take one round the waist and look in his face, we shall find his beak is just the shape for cutting the water : it is a paragon of strength, yet offers no resistance: like the keen edge of an axe, it cleaves its own passage, the body following, as a matter of course. The ribs and channels of the beak are very curious; possibly the ribs give additional strength, and both they and the channels are so arranged as to offer no resistance whatever. But the nostril is the most remarkable : it is a long slit, close to the mouth, and by passing a straw into it, you find that its opening is so managed that it would be impossible for the water to get in, however rapid the bird's course. As in the whole tribe of auks, to which this funny-looking bird belongs, the wings are short, and the legs are placed far behind, so that in under-surface swimming both legs and wings serve as fins to propel it through the water. Its chief food is fish, and with these it feeds its young : the head of the fish is is kept in the bird's mouth, which ends on each side in a little 'India-rubber' kind of ring; this gripes the fish just abaft the gills, and the fish's tail hangs dangling down. 


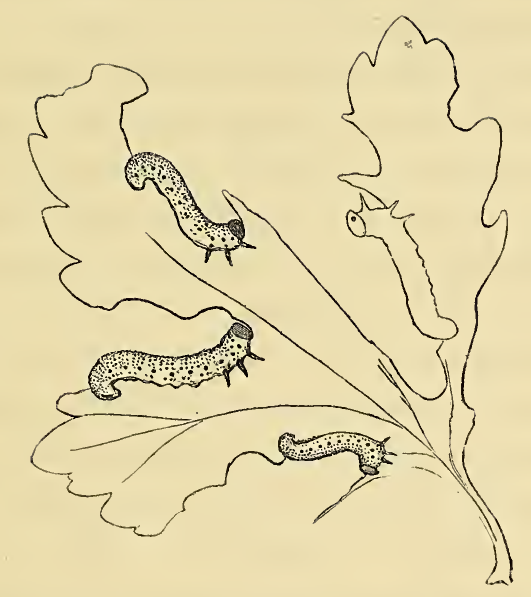

GOOSEBERRY-GRUBS OF THE NATURAL SIZE.

\section{CHAPTER IV.}

IT was immediately after my return from the Isle of Wight, that I 'revised,' as the book people say, a lot of mems, made at divers times, about those insects that are universally, but as I think ignorantly, known by the name of ' blight :' and here they are.

Blight is a term generally misunderstood; especially among those whom it more particularly concerns. The knowing horticulturist will tell you, "There is blight in the air to-day:" and in a few days or weeks, he will see the web of the lackey, or the yellow-tail, or the ermine, on his white-thorn hedge-rows; or the caterpillars of the death's head hawk-moth on his potatoes ; or those of butterflies on 
his cabbages ; and then he will give you a toss of his wise head, and utter, with a gravity quite in keeping, "I knew there would be a blight this year; I saw it coming in the air." Perhaps, however, he may find a good many snails eating his wall-fruit; or may, perchance, tread on two or three great stag beetles while performing their evening perambulation along his gravelled walks; and then, he " knew it would be either a blight or a sneg; but it's more of a sneg this year." Further than this, the horticulturist has not progressed; webs and soft insects are 'blights;' snails and hard insects are 'snegs.' Warm south-east winds produce the first ; cold north-east winds, the last ; and yet the same man would laugh in your face if you were to say seriously, on a cold misty morning, "There will be a rise in the funds tomorrow, I can see it in the air." I maintain that there can hardly be a greater service performed to horti- and agri-culturists, than by pointing out to them the nature and habits of their insect enemies; and their laughing at us in the first instance, will perhaps be repaid by their thanking us at last.

I have never known the GooseberRY-GRUB * such a unisance as it has been this year. In April I saw the fly very busy on the wing, and it continued so to the middle of May. I prophesied the havoc it would make, but I managed to save my own gooseberries by keeping the garden in a cloud of smoke for the benefit of the apple-trees; a practice not altogether grateful to the optics or olfactories, but decidedly beneficial to the fruit-crops, not that the

* It is necessary to observe that in arranging these Letters for the press, I have disregarded the chronological order of their appearance. The present letter on the gooscberry-grub was the last written, having been printed in the "Entomologist, so lately as August, 1841. Those which follow were originally published about eight years carlicr,- $-\boldsymbol{E}$. N. 
fruit thrives on smoke, but that the enemies of fruit abominate it. In many of my neighbours' gardens, the gooseberry-bushes are all but dead : the old stems are naked as in winter, and the shoots of the year so withered, shrunk and lithesome, that you might tie them in knots without breaking them: and then the poor gooseberries are shrivelled into disgusting abortions, after making a futile attempt to redden into ripeness.

Now the history of the pest is on this wise. Unconnected with its object, that of giving birth to one of the greatest nuisances that ever afflicted a fruit-garden, the parent fly is a pleasing and good-looking insect, and is rather a favourite with gardeners, who think it the harmless harbinger of the cloudless skies which accompany its visit. I have often watched these flies glancing in the sunshine, chasing each other over the leaves, spreading out their gauzy and glossy wings, the hind wings projecting from beneath the fore wings, like those of the lappet-moth, and enjoying to the top of their bent the genial influence of that delicious mock summer which we always have before the chill eastern blasts which usher in the real one, and which are supposed to bring the grub into existence. I will describe the fly : the wings are four, perfectly transparent, and in bright sunshine reflect the tints of the rainbow: the head and antennæ are black: the thorax is yellow, with a large black spot above and below, the upper spot is generally divided into three: the body is of a clear, delicate,

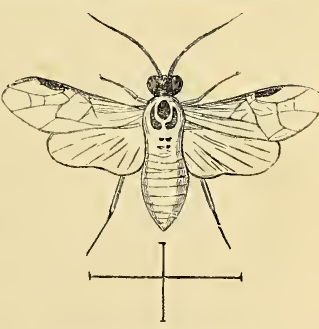

GOOSEBERRY-FLY. unspotted yellow: the legs are yellow and the feet black. I send you drawings of the fly, the leares and the grub, 
which, if you copy faithfully on wood, will greatly add to the interest of this history. The fly is magnified, but the cross below it shows the natural size. The life of the fly is but another example of implicit obedience to Nature's universal law, the heaven-descended command, "increase and multiply."

Very shortly after the due celebration of the nuptials, the female repairs to the under side of a leaf, and standing directly over its midrib, her back downwards, her wings closely folded, and her antennæ stretched straight out and continually shivering, she bends her saw under her, so as to give her body a curve, and deposits her first egg on the rib itself; then a second, a third, and so on to the tip of the leaf, or as near the tip as she can find convenient standing-room. She then goes to one of the side ribs, then to another, and so on, till all the principal ribs are garrisoned with her eggs ranged in the prettiest rows; the eggs are very long, and are placed lengthwise, end to end, like oblong beads on a string, yet not touching, for there is generally a space of about half an egg's length between each two. The eggs are very soft, and of a half-transparent white colour. After the first day the eggs begin to grow, and before the end of a week they have grown to three times their original size: the head of the egg is always towards the tip of the leaf, and is remarkable for having two black eyes, placed very far apart, and quite on the sides, indeed so far asunder are these eyes, that, like the behind buttons on the coat of a certain illustrious coachman, immortalized by Dickens, it is very difficult to bring both into the same field of view.

It is seldom more than a week before the grub makes his exit from the egg and his entrance into active life, but the 
period is not a constant one, varying from four to twelve days; he comes out head foremost, his head, by the way, like that of most young animals, being of unseemly size : his body is nearly transparent, but just tinged with smokecolour ; the eyes so conspicuous in the egg still being very observable, but as the head becomes darker these gradually disappear. The grub is ready to begin eating directly, so crawling down from the rib he commences operations on the fleshy part of the leaf, in which he gnaws a little round hole. Immediately after making his first meal, the green of the leaf communicates its colour to his body, and he is forthwith a green, instead of a smoke-coloured grub, but still so transparent, that the particles he has eaten show through his skin as a green line down the middle of his body, and it is this green line which tinges all the other parts. The little grubs descend from the rib in equal

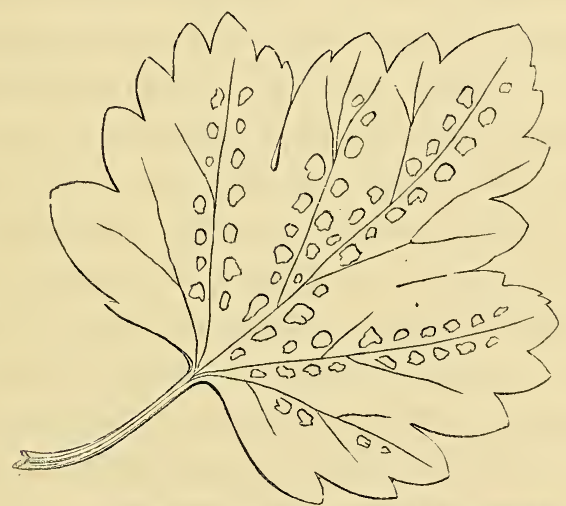

LEAF EATEN BY YOUNG GOOSEBERRY-GRUBS

numbers, right and left, leaving the skins of the eggs attached to the rib, and looking like a row of empty silver purses. The depredations are now visible above, from the 
sudden appearance of small round holes ranged in irregular rows : in each of these holes one of the tiny gluttons may be seen clasping the eaten part of the leaf between his legs and elevating the end of his body in the air. I give you a sketch of the leaf, showing this first stage of the evil, because at this period the progress of the plague may be arrested, and I consider it important to make horticulturists acquainted with its exact appearance : the grubs are too small to be shown, you will therefore understand that the appearance of the leaf is all that $I$ aim at in the figure. At this nick of time, by a little care and industry, you may save your gooseberries. Now that leaf has sixty-seven grubs feeding on it: each grub will eat three leaves before it is full fed : argal, if you destroy that one leaf and all its inhabitants, you save two hundred and one leaves. If you have no time to look for these leaves yourself, get some children to do it; they will soon take an interest in the occupation, particularly if backed by a few coppers : surely you would not object to give a child a halfpenny a score for such leaves, and that price would be quite sufficient to clear the vision and sharpen the intellects of many a hungry boy. I would also recommend young ladies to look after such leaves, and pick them into a hand-basket, the contents of which may be emptied into a bucket of water standing near, or disposed of in a variety of ways. If you neglect the trees at this critical time, each infested leaf will be quickly stripped of all its green, the ribs alone remaining : the grubs then descend its foot-stalk, and wandering in different directions each finds a leaf for himself, and the work of devastation begins in earnest.

The grub is known to every gardener, indeed so well known, that you may perhaps consider it a waste of time 
and paper to describe it here; yet some of your readers may be glad of a description, so here it is. There is a great difference between the grubs of saw-flies-the gooseberry grub is that of a saw-fly - and the caterpillars of moths, which your thorough-paced entomologists don't seem to have noticed. The caterpillars of moths and butterflies have six legs, and ten, six, or four holders, two of which are quite at the end of the body, and are very powerful prehensile organs, excepting - and the exception establishes the rule - in the caterpillars of puss-moths and their allies, in which the hinder extremity is without these organs, and often elevated in a most remarkable manner. In all the grubs of saw-flies that I have seen, the tail or last segment of the body is either without holders, or the grub does not use them, but just curls its tail on one side and uses it after the fashion of a finger, to steady its hold on the leaf, or else sticks it up in the air, and even then the extreme end is curled round, though holding nothing. The legs are longer than those of real caterpillars, and have more joints. The gooseberry-grub has six legs, and in this all insects that have any legs at all seem to agree, and twelve holders, besides the curled tail: it always stands on the edge of the leaf, generally on the part where it has just been eating : the fore legs are held away from the leaf, and move with each movement of the head in gnawing, as the grub takes mouthful after mouthful. It is amusing to watch one of these fellows feeding; he stretches his mouth to the farthest point he can possibly reach, and then takes mouthfuls by a series of jerks, till he has brought his mouth nearly in contact with his middle pair of legs, he then moves it slowly back again, and seems to lick or plane the fresh-gnawed edge, till he gets 
his neck stretched to its fullest reach, and he then brings it up by jerking out mouthfuls as before. The middle and hind legs, as well as the holders, grasp the leaf very tight during the operation of gnawing, which is almost incessant. The head of the grub is now quite black, and its eyes are no longer to be seen: the colour of the body is a dull, bluish green, with a yellowish space just behind the head, and another just before the tail ; it is indistinctly divided into twelve rings, and each ring has a number of black warts; these warts, upon all the rings except the first, second, third and twelfth, are ranged in three indistinct transverse rows, and on each side of each ring is one larger and more conspicuous wart; from each wart rises a strong, upright, black bristle, and there are several of these bristles on the head itself; the last ring has a black plate, ending behind in two short rather hooked points.

When about half an inch in length, the grub leaves off eating, a very remarkable event, for its appetite is not intermittent, like that of almost all other created beings, but a continued gnawing, craving, never-ceasing, all-consuming propensity. The black head separates from the neck and splits down the middle, and the skin of the neck also splits, thus together making an opening large enough to let the grub poke out his new head, which feat he forthwith performs, and gazes about him, moving his head slowly and majestically from side to side, as though he were just landed in a new world, though a world totally unworthy any expression of wonder or approval : after the head comes the body, which is wriggled through the opening by tedious, laborious, and seemingly painful struggles. When the skin is completely cast, the grub has none of the black spots which before distinguished it, the warts and 
black hairs are present, but the warts are colourless: the head is clear as glass, and the two black eyes, so conspicuous in the egg and newly-hatched grub, are again visible. In about twenty minutes the black spots begin to appear, and in about four hours become as distinct and the head as black as before the moult. When the grub has regained its colour, it again begins to eat, and eats away night and day without stopping, for four or five days more. It then sickens again for its last moult, and this is performed in the same way as the first: but this time the spots, warts and bristles are cast with the skin and appear no more. The grub is now of a pale delicate green colour, except the yellow patch near each end, which it still retains. It has now done with eating: when hard enough and strong enough after this last moult, it marches to the stem of the bush, and quietly descends till it reaches the earth: sometimes it crawls along a hanging branch and drops from the extremity.

The object of gaining the earth is to burrow beneath its surface; and as soon as the grub once feels the soil, he begins forcing his way into it head foremost, after the fashion of a mole. When he is deep enough to answer his purpose, the depth varying, by the way, from two to eight inches, according to the hardness or lightness of the soil, he makes a little oblong cell in the earth, and therein spins or constructs a tough black cocoon, attached all round to the walls of the cell : although I say spins, the material he uses is not silk or thread, but something between silk and glue, or what we might suppose to arise from the hardening of fluid silk, an illustration rather of the uncouthest, but for want of a better, it must go. In this cocoon or case he disposes himself to await the change to a chrysalis, and soon after to a fly. 
The time occupied in this round of existence is very variable : many of the eggs laid in May, before the middle of the month produce grubs that go through every change and are on the wing by the 24th of June; and eggs laid about that day, will go through their changes as far as the cocoon by the 10th of July, or 15th at the latest: the first brood thus taking about twenty-eight days, and the second generally remaining under ground till the next spring. It is not however clear that in all instances this insect has two broods: on the contrary, I am nearly certain that many of the late hatches never reproduce during the year, but the time of their first appearance is so variable, that a constant succession is kept up, the earliest having reproduced before the later hatches are gone down.

In my war on blight I always weigh well the remedies : many a tree has been killed to get rid of its blight; this plan is efficient but impolitic, energetic but unwise : some will white-wash a gooseberry-bush, the effect of which is cheerful and pleasing to the eye but rather injurious to the leaves, and moreover gives a very unpleasant flavour and grittiness to the berries: some will water the bushes with strong brine, thereby greatly annoying the grub by killing the leaves : quicklime has a very similar effect. It strikes me that no nostrum will ever be found that shall be perfectly efficient as regards the grub and harmless as regards the tree: it would therefore be my plan to attempt to lessen an evil that is not to be cured. I have already mentioned the good effects of smoke; the picking of the perforated leaves I have also recommended: another benefit will arise from treading the ground very hard about the roots of the bushes. An observant gardener cannot fail to notice that when gooseberry-bushes stand singly at the end 
of patches of potatoes, peas or beans, they are sure to be more infested than when in a close bed: the reason for this seems to me that the soil for all our culinaries is made as light as possible; this is effected by constant digging, hoeing or raking: in a bed filled with gooseberry-bushes, on the contrary, there is but little moving of the earth going on, and it gets trodden hard when the gooseberries are ripening, and commonly remains so through the year. This hardening of the soil prevents the grubs from burrowing when they come down fiom the bushes, so they go wandering about and become a prey to the hedge-sparrows, house-sparrows, whitethroats, robins, and obese toads that are always on the look-out for them : it also prevents so feeble an insect as the fly from forcing its way upwards from the cell in which it has changed; thus those on the surface and those under the surface are alike assailed by the simple expedient of hardening the soil. I have tried numberless experiments on the grubs themselves, and find them very easy to kill: brine, tobacco-water, snuff-water, and other mixtures are fatal; but these remedies, like the once celebrated flea-poison, require the capture of the animal in order to their being administered with effect.

The true blight, or ApHIs, is a quiet, dull, stupid looking animal, mostly without wings, but he sometimes has four, two of which are much larger than the other two, and fold over and hide them, reaching beyond the body and meeting together behind it ; these wings are generally as clear as crystal, with a few veins in them, yet if you hold the insect in the sunshine, and examine him through a glass, you will find they take all the colours of the rainbow; you will also find he has a long trunk or sucker, which is used as a pump or siphon, through which the 
sap of plants is drawn up. I have sometimes seen this sucker so long as to pass under the breast and legs, and reach a considerable distance behind the body, but it is not generally so. All blights infest the young and juicy shoots, and leaves of plants, for the purpose of sap-sucking; and the plants honoured by their operations forthwith play the most amusing and incredible vagaries; bearing blossoms instead of leaves, leaves instead of blossoms; twisting into corkscrews stems which ought to be straight, and making straight as sticks those which, as the scarletrunner and hop, ought to twine; sometimes, as in the peach, making the leaves hump up in the middle, and causing the tree to look as though it had a famous crop of young fruit; making apple-trees bear blossoms on their roots, and causing roots to grow out of their young shoots; and, by tormenting orchards in this way, preventing the fruit from ripening, and making it woolly, tasteless, and without juice. It is amusing to see with what regularity the blights station themselves on the young shoots of the guelder-rose, crowding so close together that not a morsel of the rind is to be seen, and not unfrequently forming a double tier, or two thicknesses; the poor sprig losing its formal, unbending, upright position, and writhing itself into strange contortions.

Blights are of all colours, * but green is their most fashionable hue; those of broad-beans are black as soot, and velvety, - and these, if attended to, do but little harm; they cluster at the very top, and each bean should be topped just below the blight, and the top carried away and

* Until lately the species of Aphis have not been technically described by entomologists: Mr. Walker is now publishing descriptions in successive number's of the 'Zoologist.'-E. $N$. 
burnt, - not thrown on the ground, - or else the blights are sure to climb up the stalks again, and, stopping here and there at the best landing-place, increase and multiply, and soon cover the whole plant; nor should they be buried in the ground, for the blights take care to outwit you by living underground for months, and when the gardener's spade turns them up again, they make for the beans directly : the plan of topping the beans does not injure the crop, but, if carefully done, rather improves it. The blight of the willow is very large, and, at first sight, looks grayish, but under a glass is beautifully variegated with black and white; when crushed it gives out a deep, blood-coloured dye, which stays on your hand several days in spite of frequent washings.

I have taken a good deal of pains to find out the birth and parentage of true blights; and for this purpose have watched, day after day, the colonies of them in my own garden, and single ones which I have kept in-doors, and under tumblers turned upside down; the increase is prodigious; it beats everything of the kind that I have ever seen, heard, or read of. Insects in general come from an egg, - then turn to a caterpillar, which does nothing but eat, - then to a chrysalis, which does nothing but sleep,then to a perfect beetle or fly, which does nothing but increase its kind. But blights proceed altogether on another system : - the young ones are born exactly like the old ones, but less; they stick their beaks through the rind, and begin drawing sap when only a day old, and go on quietly sucking away for days; and then, all at once, without love, courtship, or matrimony, each individual begins bringing forth young ones, and continues to do so for months, at the rate of from a dozen to eighteen every day, 


\section{and yet continues to increase in size all the while; there seem to be no males, no drones, - all bring forth alike.*}

* The study of this obscure tribe of insects has not been attended with any great success, neither has it enabled us to arrive at very positive conclusions concerning this apparently anomalous mode of reproduction. Some authors assert that the same individual female at one period of her life produces living young and at another period is truly oviparous: others contend that the oviparous and viviparous females are perfectly and constantly distinct; indeed $\mathbf{M r}$. Walker goes so far as to describe six different kinds of individuals of the same species, viz., 1, a winged oviparous female; 2, a wingless oviparous female ; 3 , a winged viviparous female; 4 , a wingless viviparous female; 5 , a winged male ; 6, a wingless male. My own observations, interrupted and incomplete though they be, tend to favour the view evidently entertained by our author, that the wingless female is the parent of the winged female, and that the latter is generally oviparous, while the former is generally viviparous : exceptions certainly occur. On the other hand, I lave never met with an instance in which an oviparous individual became viviparous, or vice versâ : but in support of such a fact I will quote from the 'Zoologist' (Zool. 2002) an able paper recently published by Mr. Newport.-E.N. "The history of the plant-louse, as ascertained by Leeuwenhoek, Bonnet, Reaumur, and others, is so generally known to naturalists, that it is almost an act of supererogation for any one merely to repeat the observations of those authorities; and we cannot expect to add much to the very ample details they have given : yet the facts they have recorded respecting the generation of Aphides are in themselves so exceedingly curious, and at the same time are so unexplained by any hitherto receiver theory of generation deduced from observations on vertebrated animals, that $I$ have been desirous of verifying these facts by direct experiment, preparatory to attempting hereafter to show their accordance with some tniversal law of reproduction. I trust, therefore, that I may now le permitted in this short note to bear testimony to the correctness of the observations of Leeuwenhoek, Bonnet and Reaumur, on the mode of generation in the Aphides, although at present $I$ can add but little to what has already been observed by those naturalists. The facts I have more particularly endeavoured to investigate, are - first, whether the Aphis is in reality viviparous at one season, and oviparous at another? and next, whether the supposed ova are deposited as true eggs; or whether, as imagined by some observers, they are only capsules designed to protect the already formed embryos during the winter season? With these objects in view, I selected the Aphis of the rose, as best fitted for the inquiry. In the beginning of November, 1842, the young shoots of a rose tree, that had remained in the open air during the whole of the preceding summer, were thickly covered with Aphides, amongst which $I$ had not yet seen any winged specimens; neither had 


\section{Early in the year these blights are scattered along the stems, but as soon as the little ones come to light, and}

any of the females yet deposited ova. The rose tree was placed in the window of an apartment in which there was no fire, and where the temperature ranged from about $45^{\circ} \mathrm{Fahr}$. to $50^{\circ} \mathrm{Fahr}$. In the second week of November, as the temperature of the season became cooler, I first noticed several specimens with rudiments of wings, and a few days afterwards these cast their skins and became fully developed. Most of these individuals were males. At this time there were also a great many very young specimens. On the 30 th of November the number of winged individuals had greatly increased; there were many with only the rudiments of wings: and there was also a great abundance of black oral eggs distributed everywhere on the young shoots of the plant, not only on the leaf-buds, but on the stems of the leaves and branches. I saw an Aphis at that moment bearing two eggs at the extremity of her body. On placing one of these beneath the microscope, I was quickly assured of its real nature: it was not a capsule that included a ready-formed embryo, but a true egg. When first deposited the egg is of an orange-yellow colour, but it soon acquires a much darker hue, and ultimately becomes of a deep, shining black. The colour is entirely dependant on the pigment of the shell, and is much darker in some specimens than in others. The eggs are firmly glued to the plant, and are not easily removed. The egg of the Aphis is similar to that of other insects; it is composed of an orange-colored yelk, formed of yellow, nucleated cells, and surrounded by a very slight quantity of transparent vitelline fluid. It contains also a very large germinal vesicle, with a distinct macula or nucleus. This vesicle is three or four times as large as the cells that compose the yelk, and, unlike that of most other impregnated eggs of insects, does not disappear until some time after the egg is deposited. The vesicle is so persistent, that in one instance in which I examined an egg, shortly after it came from the body of the Aphis, it did not disappear for several seconds after the egg was crushed under the microscope.

"Wishing to observe the deposition of more eggs, I selected four specimens of the Aplis for experiment: two of these were males, which as yet were in the pupa state, and had only the rudiments of wings; the other two were large apterous females : these were placed on a detached branch of the rose, inclosed in a stoppered glass vessel, and removed to an apartment in which the temperature ranged from $55^{\circ} \mathrm{Fahr}$. to about $60^{\circ} \mathrm{Fahr}$. On the 2nd of December, when the temperature of the room was $58^{\circ} \mathrm{Fahr}$., I. was surprised to find that these specimens were again producing living young. One of the large apterous females had already produced its living offspring, and the other was at that very moment in the act of parturition. The posterior part of the body of 
commence sap-sucking close to their mother, the spaces get filled up, and the old ones look like giants among the rest,-as here and there an ox in a flock of sheep - when all the spare room is filled up, and the stalk completely covered. The young ones, on making their first appearance in the world, seem rather posed as to what to be at, and stand quietly on the backs of the others for an hour or so; then, as if having made up their minds, they toddle upwards, walking on the backs of the whole flock till they arrive at the upper end of the shoot, and then settle themselves quietly down, as close as possible to the outermost of their friends, and then commence sap-sucking like the rest; the flock by this means extends in length every day, and at last the growing shoot is overtaken by their multitude, and completely covered to the very tip. Towards autumn, however, the blights undergo a change in their nature, their feet stick close to the rind, their skin opens along the back, and a winged blight comes out - the summer generations being generally wingless. 'These are male and female,

a young Aphis was then protruding from that of the parent, and was quickly followed by the remainder of the body, the thorax and the legs. When these parts had passed, there was a slight cessation of parturient action, the head being still retained in the vaginal passage. The disengagement of the head seemed to be the slowest part of the process. The manner in which the parent rid herself of the new-born Aphis was deserving of notice. When the little insect was almost entirely extruded from her body, it clung with its feet to the plant; while the female Aphis, at short intervals, gradually elevated her body, and with a slight jerk seemed to labour to remore it. The young Aphis repeatedly missed its hold, but quickly regained it, and was thus as it were partially dragged forth. The head, with its small black eyes, parts of the mouth, and the antennæ, were thus gradually withdrawn, but I could not detect any foetal coverings removed with them. The whole process of birth occupied about five uninutes. Immediately after the young had cscaped from the parent, it 
and fly about and enjoy themselves, and, what seems scarcely credible, the winged females lay eggs, and whilst this operation is going on, a solitary, winged blight may be observed on the under-side of the leaves, or on the young shoots, particularly on the hop, and differing from all its own progeny, in being winged and nearly black, whereas its progeny are green and without wings.* These are mysteries which I leave you entomologists

turned about on the leaf and moved very slowly, while the female plunged her proboscis into the plant to take food after her exertion.

"These brief observations confirm the statements of former naturalists, that the Aphides deposit at one period true ova, and at others produce living young; and they lead us hereafter to inquire more particularly respecting the circumstances which accelerate the one, or retard the other form of development."-George Newport, F.R.S., in 'Transactions of the Linnean Society.'

* Mr. Walker has obligingly furnished the following detailed descriptions.

The hop-fly, Aphis Humuli, Schrank, Fauna Boica, ii. 110, $1199 . \quad$ Kaltenbach, Mon. Pfan. i. 36, 24. A. Pruni Mahaleb, Fonscolombe, Ann. Soc. Ent. Tr. x.

The migration of some species of Aphides from the plants whereon they pass the winter in the egg state, to different kinds of plants which afford them summer pasture, is one of the most interesting facts in their history. The food of Aphis Humuli is divided between the sloe and the hop, and when the latter is wanting the insect probably lives only on the sloe, or perhaps sometimes on the plum, and is limited to the districts where these trees grow, but their general distribution gives the fly ready access to the hop.

The Viviparous Wingless Female of the first Generation. - This is hatched from the egg in the spring, and swarms throughout May on the sloe, which is also the food of three other species, and there are at least two more kinds that live on the plum. It is grass-green, oval, and very plump, and the whole body is crowded with young ones: the front of the head is slightly convex, but not notched : there is a tubercle like a little horn or joint on the inner base of each antenna ; this process is possessed by many other species, but in a less developed form : the antennæ are setaceous, and about half the length of the body ; there is a slight projection on the tip of the first joint; the fourth joint is much shorter than the third, but more than half its length; the fifth is a little longer (whereas in most species it is shorter) than the fourth; the sixth is less than half the length of the fifth; the seventh is much more slender than the 


\section{to explain. In May, a fly lays a lot of eggs ; these eggs hatch and become blights; these blights}

preceding joints, and rather longer than the fifth; the rostrum reaches the middle hips, its tip is brown; the eyes are red ; the sides of the forechest are, as usual, slightly notched; the tubes are nearly one-fourth of the length of the body, and slightly decrease in thickness from the base to the tips; the legs are moderately long; the fore legs are considerably shorter than the hind legs; the tibiæ are very slightly bent ; the number of unborn little ones visible together is between thirty and forty, so homogeneous is the body, and so generally possessed of the reproductive faculty; the horn on the front is sometimes slightly forked at the tip, and one specimen has a fore tibia quite black.

The Viviparous Winged Female of the second Generation. - This acquires wings at the end of May, and in the beginning of June it repairs in great numbers to the hops, and in a few instances it continues there till the end of July : it is green; the disk of the liead and the mesothorax above and below are black; there are a few black bands across the disk of the abdomen, and a row of large black spots on each side, the tip of the abdomen, like that of the wingless female, forms a short tube; there is a conical protuberance in the middle of the front, the projection on each side is shorter than that of the wingless female; the antennæ are black, and a little longer or a little shorter than the body; the base of the third joint is pale green ; the fifth joint is a little shorter than the fourth; the sixth is little more than one-third of the length of the fifth; the seventh is very much longer than the fourth; the rostrum is pale green, with a black tip; the tubes are dull green, with black tips: the legs are pale yellow, and longer than those of the wingless female; the thighs, especially the hind thighs, are black from the tips towards the base; the tarsi and the tips of the tibiæ are also black; the wings are colourless; the squamulæ are pale yellow; the stigmata are pale brown; the veins are brown; the costal vein, a little beyond the middle of the fore border of the wing, begins to widen into the stigma, which is irregularly spindle-shaped, rather long and narrow, and has a very slight obtuse angle on its hind border; the branch veins are very distinct; the first and the second are nearly straight; the third is obsolete near its source, and is forked soon after one-third, and forked again at two-thirds of its length, it is inclined towards the tip of the wing, and forms two very obtuse angles where it casts off its forks. The pupa is green, like the wingless female, but is elliptical, and has a narrower body.

Irregularities in the Veins of the Wings.-1st. The second fork is sent forth much beyond two-thirds of the length of the third vein. 2nd. The first fork does not begin till the middle of the third vein. 3rd. The second fork is wanting. 4th. The first fork is wanting. 5th. The first fork is partly wanting, 
are viviparous, and that without the usual union of the sexes, and so are their children and grandchildren, - the number of births depending solely on the quantity and quality of their food: at last, as winter approaches, the whole generation, or series of generations, assumes wings, which the parents did not possess, undergoes frequently a change in colour, and instead of being viviparous, lays eggs.

To this singular tribe belongs the Hop-FLY, an insect

and its stump runs very near the third vein. 6th. The second vein is forked at its tip. 7th. The second vein is wanting, except near its source. 8th. A third fork is sent forth with the second. 9th. Both branches of the second fork cease soon after their source. 10th. One branch of the second fork is wanting, except at its tip.

The Viviparous Wingless Female of the third Generation.-This is very different from that of the first generation, being much smaller, narrower, paler, and more flat; the hody is long-elliptical or spindle-shaped, when young it is greenishwhite, and half transparent; the limbs are white; the antennæ are a little more than half the length of the budy; the eyes are black; the tubes are about one-fifth of the length of the body, when full grown it is a little broader, and of a grass-green colour; the tarsi and the tips of the antennæ, of the mouth, of the tubes, and of the tibiæ are black; the horns on the front and the projections on the first joints of the antennæ are still more developed than in the first generation ; the tubes are cylindrical, and of an equal thickness throughout.

1st Variety.-The antennæ, excepting the base, are black.

2nd Variety.-The body is pale green, with interrupted, darker green bands. It is not so prolific as is the first generation, but far more numerous : the body is narrower when it feeds on the hop than when on the sloe, where $I$ have found it in the middle of July, and it sometimes occurs there in great profusion towards the end of that month, and is accompanied by the winged female, and also by the pupa of the fonrth generation, wliose horns on the front are more developed than when it acquires wings, but less so than those of the wingless female. The third generation on the sloe is sometimes infested by the little red Acarus, Leptus Aphidum, and occasionally great numbers of Formica rufa come to feed on its honey. Length of the body $\frac{3}{4}-1$ line; of the wings $2 \frac{1}{4}-2 \frac{3}{4}$ lines. $-F$. Walker. 
which has more rule over the pockets and tempers of mankind than any other; its abundance or scarcity being the almost only criterion of a scarcity or abundance in the crops of hops: and of all articles of merchandize the hop is consequently the most liable to variation in price. Owing to the interest taken in the crop of hops, much more close attention has been paid to the hop-fly than to any other insect; and you find men conversant with its habits, who would blush if you were to suppose them possessed of enough natural history to know the name of the commonest beetle or even bird; but let me assure these, that there is nothing derogatory to their manhood, their common sense, or their dignity, in knowing something of the works of Nature; I never met with an individual who was the worse man for it. I don't myself go the length of some of your contributors, who measure the joints of an insect's ears, as Professor Rennie, I see by your Magazine, has called them. But, perhaps, even this is necessary to acquire an accurate knowledge of each kind.

The hop counties are Kent, Sussex, Surrey, Worcester, and Hereford. The produce of these are termed, on the market, Kent, Sussex, Farnham, and Worcester hops. The Farnham are invariably the highest priced, and the Sussex the lowest. The Worcester hops never come on the London market, and have a price of their own, which is not much influenced by the general price, as no hops are ever, or very rarely indeed, introduced to supply a deficiency of the Worcester crop, should that fail. The hop affords scope for the speculator in two ways: first, the hop itself; and, secondly, the hop-duty; the last is the subject of betting to a very large amount annually. The old duty on hops is $10 s .8 d$. per cwt.; the new duty, imposed in 
1802, is $12 s .7 d$.; making, with the fractions, $23 s .4 d$. ; in $1805,4 s .8 d$. per cwt. was reduced; so that the actual duty paid is $18 s .8 d$. per cwt. In betting on the duty, the old duty is always understood; and so generally adopted is this plan of expressing the probability of a crop by the betted duty, that the common question is, "What is the duty laid at?" and as the duty falls, the price of hops, of course, rises; and vice versâ. This duty is, however, too much guided by a few men in the Borough, who frequently rise and fall it to answer their own purposes; yet, as the day of picking approaches, the near correspondence of the betted duty and the old duty actually paid, is truly surprising. In the year 1802, on the 14th of May, the old duty was laid at 100,000l.; the fly, however, appearing pretty plentifully towards the end of the month, it sunk to $80,000 l$.; the fly increased; and, by the end of June, the duty had gone down to $60,000 l$.; by the end of July, to $30,000 l$.; by the end of August, to 22,000l.; and by the end of December to $14,000 l$.; the duty actually paid this year was $15,463 \mathrm{l} .10 \mathrm{~s}$. $5 \mathrm{~d}$. In 1825 , the duty commenced at 130,000l., but, owing to the excessive increase of the fly, had in July fallen to 16,000l.; at the beginning of September it rose to 29,000l., but towards the end fell again to 22,000l.; the amount paid was 24,317l. 0 s. 11 . In the following year the summer was remarkably dry and hot; we could hardly sleep of nights with the sheets on ; the thermometer for several nights continued above $70^{\circ}$ all the night through: the crop of hops was immense, scarcely a fly was to be found, and the betted duty, which began in May at $120,000 l$., rose to $265,000 l$. ; the old duty actually paid was $269,331 \mathrm{l}$. $0 \mathrm{~s} .9 \mathrm{~d}$.; the gross duty, 468,401l. 16s. 1d., being the largest amount ever known. From 
this it will appear that, in duty alone, a little, insignificant looking fly has control over 450,000l. annual income to the British Treasury; and supposing the hop-grounds of England capable of paying this duty annually, which they certainly are, it is very manifest, that in 1825 , these creatures were the means of robbing the Treasury of $426,000 \mathrm{l}$. This seems a large sum, but it is not one-twentieth part of the sums gained and lost by dealers during the two years in question.

The hop-fly makes its first appearance generally about the 12th of May, sometimes two days earlier, but almost invariably between the 10th and the 30th; and it is worth noticing, that it usually appears on the same day in the four districts of Kent, Sussex, Farnham, and Worcester. It always makes its first appearance in the winged state, a solitary fly being found settled very quietly here and there under the young leaves. If the weather is warm, with mild, kind rains during the last twenty days of May, these flies begin to produce young ones, which are very small, and are called deposit, or knits. These grow very fast, and in a few days become green lice, which is merely a larger form of the same animal. These lice very soon begin to breed, and so keep on, knits and lice, knits and lice only, to so great an extent as to destroy the plant, when they appear to die with it. I have never found that the deposit of the hop-fly leaves the plant at all, or ever becomes a fly while there: in this respect differing from the Aphis of the rose, guelder-rose, bean, \&c., of which I have spoken above. Frequently, when the weather in May has been dry, and cold, and windy, the fly has been known to leave the plant, and entirely disappear, even after remaining several days; yet whilst it tarried showing very 
evident signs of being uneasy, continually crawling about on the upper as well as the under side of the leaves, and leaving no deposit whatever. The direction of the wind has nothing whatever to do with their first appearance, but in a warm, westerly wind they will take flight most readily, and be thus distributed. The lice, when half grown, change the skins; and I have often found the skins of very large ones stuck to the leaves, and yet showing no opening where the insect could have got out. I beliere these are the prey of a little parasitic fly, whose history I don't know enough of at present to attempt to give it you here ; they have, however, other enemies; and as these seem to offer the only hope of checking the increase of these destructive wretches, I shall give you a little account of them.

You will never find a plant of any kind infested with the Aphis, without also observing a number of ants and lady-birds among them, and also a queer-looking insect, like a fat lizard, which is, in fact, the caterpillar of the lady-bird. The connexion of the ants and the Aphis is of the most peaceful kind that can be conceived; their object is the honey-dew which the Aphis emits; and, far from hurting the animal which affords them this pleasant food, they show it the greatest possible attention and kindness, - licking it all over with their little tongues, and fondling it, and patting it, and caressing it with their antennæ in the kindest, prettiest way imaginable:- not so the lady-bird, or its lizard-like caterpillar; these feed on the blights most voraciously, a single grub clearing a leaf, on which were forty or more, in the course of a day. The perfect lady-bird is a decided enemy to them, but not so formidable a one as the grub. The eggs of the lady-bird 
may often be seen on the hop-leaf; they are yellow, and five or six in a cluster placed on their ends; these should on no account be destroyed, as is too often the case, but on the contrary every encouragement should be given to so decided a friend to the hop-grower.

Besides the lady-bird and its grub, there are two other terrible enemies to the poor Aphis; one of these is a green, ungainly-looking grub, without legs, which lies flat on the surface of the leaf, and stretches out its neck, just like a leech, till it touches one of them; directly he feels one he seizes it in his teeth, and holds it up, wriggling in the air, till he has sucked all the goodness out of it, and left a mere empty skin. This curious creature turns to a fly which has a body banded with different colours, and which in summer you may often observe under trees and about flowers, standing quite still in the air as though asleep, yet, if you try to catch him, darting off like an arrow.* The other has six legs, and very large, strong; curved jaws, and is a most ferocious looking fellow, strutting about with the skins of the blights which he has killed on his back. This fierce fellow comes to a very beautiful fly, with four wings, all divided into meshes, like a net, and two beautiful golden eyes. $\dagger$ All these creatures, which thus live on the plant-lice, have a very strong and disagreeable smell in the perfect state.

* One of the Syrphida.-E. N.

+ Chrysopa perla.-E. N.

+ I have myself witnessed the operations of a parasite that destroys an inmense number of hop-flies by a most subtle but equally certain process. The habits of this minute creature, or one closely allied, have been beautifully described by Mr. Haliday in the 'Entomological Magazine.' In the following passage, cited from 'The Grammar of Entomology,' p. 69, Mr. Haliday's description referring to the parasite of the Aplis of the rose has 
For a favourite plant infested with blight there are several remedies, - smoke of tobacco, snuff, \&c., but the most effectual, and the least hurtful to the plant, is to let it

been slightly altered in order to accommodate it to that of the hop-fly. "A fourth enemy to the hop-fly is a minute ichneumon, similar to that which is parasitical on the blight of the rose: the males of these ichneumons are active, flying about, and coursing over the leaves; but the female is of less roving habits, and will generally be found busy in providing for the establishment of her numerous progeny : placed, at her birtl, among myriads of hopflies, she has no dwelling to construct with artful industry, nor stores of food to collect by distant rovings. With extended antennæ, and wings shivering with desire, she paces leisurely amongst the defenceless herd; and as soon as she has selected one by a light touch of her antennæ, she stops short at about her own length from it, and rising on stiffened legs, bends her body under her breast till the end of it projects beyond her mouth; then, erecting her back by depressing the hinder part, she simultaneously makes a lunge forward with the body, which is then extraordinarily lengthened, and, by a momentary touch, deposits an egg on the under side of the hop-fly, near its tail. The hop-fly will sometimes kick and sprawl, so as to discompose the ichneumon; but being anchored by its sucker plunged in the bark, can make no effectual attempt to elude the deadly weapon: should it, however, be wandering at large, and free to struggle, she shows great activity, by traversing round it in the attitude of attack, till she can take it in flank. The delicate sense of the antennæ seems to warn her where a germ has been already deposited, as she will pass by those which have been stung some days before; and there is never found more than a single grub in each individual: when all the interior of the hop-fly is consumed by the grub of the ichneumon, it will be found separate from its fellows, and motionless, usually on the upper side of the leaf, to which it is glued by some viscid exudation. The hop-fly now appears distended, and of an opaque hazel or lighter tint; if opened, the full-fed grub of the ichneumon will be discovered doubled up and filling the cavity, its head being next the tail of the hop-fly ; in a short time the parts of the perfect insect are developed in a quiescent state, and in the same position, the integuments of the grub being doubled up below it in black grains: it spins no cocoon, being adequately protected by the indurated skin of its victim. A few days are sufficient to give consistence to its parts; and while the new-risen sun is yet glistening in the early dews, the winged insect, by a push of its head, detaches the latter rings of its case, which separate in the form of a circular lid, often springing back to close the orifice after the inhabitant has gone forth, born in the maturity of her energies and instincts to renew the circle of existence." 
stand in a tank of cold water for half an hour, when all the blights will leave it and swim on the surface of the water. For hops, none of these plans are available; and, unless a way could be discovered of increasing the number of the blight-eaters, I fear the chance of discovering a remedy is very small.

I don't know why our brethren on the other side the Atlantic are charged with sending us the greatest pest of our orchards, but so it is. We call an insect the AMERICAN Blight, which, for aught I could ever make out, may have come from China or Botany Bay. However, a name once in vogue will have its day; and one might as well attempt to turn a pig in an entry as argue against an established belief; so American blight it shall be. In very hot weather you may now and then see this blight on the wing; it has just the look of a bit of cotton, or a downy seed, floating in the air, and is driven by every breath of wind quite as readily. If you catch and examine it, you will find it to be just like the plant-louse which infests our rose-trees, \&c. ; but, unlike all other plant-lice, it is clothed and muffled up with cotton-wool, in such quantities, that you would at first have no more idea that the lump contained an insect, than that the mass of clothes on a stage-coach box in winter, contained a man. Some folks wonder what can be the use of so much clothing; I am not much of a theorist, but I should guess that the vermin came from the torrid zone, and Nature kindly furnishes this garment to protect them from the cold of our climate.

These blights wander wherever the wind pleases to carry them; and if bad luck should drive one of them against the branch of an apple-tree, there it will stick, creep into a crack in the bark, bring forth its young, and 
found a colony; the white cotton soon appears in large bunches; branch after branch becomes infected; the tree grows cankery, pines, and dies. How this is effected no one knows, though the plague and its doings are too evident to escape the notice of the commonest clown. In large orchards it is in vain to hope for a cure, but not so in gardens. Directly you see the least morsel of cotton, make up your mind to a little trouble and you will get rid of it. In the first place, get a plasterer's whitewashingbrush, then get a large pot of double size, make your man heat it till it is quite liquid, then go with him into the garden and see that he paints over every patch of white, though not bigger than a sixpence; the next morning have the size-pot heated again, and have another hunt; and keep on doing so every morning for a fortnight. Your man will tell you it's no use; tell him that's your business, not his: your neighbours will laugh at you for your pains: do it before they are up. I have tried it and known it to be effectual. Spirit of tar has been used with partial effect, so also has resin; whitewashing has been often tried, and, as it contains some size, is not entirely useless, and some horticulturists think it ornamental: I do not.

The Apple Weevil is a second enemy to the cider orchard. By carefully examining the bark of an apple-tree in the winter, you will occasionally find a pretty little beetle in the cracks, which, directly on being touched, shams dead, and drops on the ground, where you will not, without great difficulty, discover it, on account of the similarity of colour ; you must, therefore, hunt till you find another. This time, as soon as you see him, place one hand below him, then touch him lightly with a little bit of stick, and he will drop into your open hand; his own 
scheme for self-preservation will beat him. Now roll him into a quill or pill-box, and take him home. Place him on a sheet of writing paper; you will soon see his shapethe head is furnished with a trunk, from which, on each side, springs a feeler, bent at right angles forward, so that the trunk altog'ether looks to be three-pronged, like a trident. 'The thorax and wing-cases are brown, beautifully mottled; and an oblique line on each, pointing towards the suture or meeting of the wing-cases, is much lighter coloured, and gives the little beetle an appearance of having a letter $\mathrm{V}$ obscurely chalked on its back. Its size altogether is rather less than a hempseed.*

With the first sunshiny day in March, these weevils leave their winter quarters, crawl up the trunk and along the twigs, perch themselves so as to receive the full benefit of the sun's rays, and plume themselves with their legs and feet all over, trident and all, just in the same manner that a cat washes her face with her paws: they then stretch out one leg at a time, cramped, no doubt, by the long confinement; they lift up their wing-cases and unfold two large, transparent wings, which, though twice as long: as the wing-cases, were neatly folded up and hidden under them, and then, launching themselves into the air, they go roving about the orchards and gardens, their little hearts in an ecstasy of freedom, and love, and happiness. It is not long before each finds a suitable mate; no relations raise objections; and the nuptials are consummated. Now I will allow the gentleman weevil to go his way in quest of new loves and conquests; and in the mean time I will observe the conduct of the lady.

* This insect is the Anthonomus pomorum of authors: a second species of the same genus infests the pear, and a third the common white-thorn. $-E$. $N$. 
By the time the female is ready for the important task of depositing her eggs, the spring has considerably advanced, the apple-buds have burst, and the little bunches of blossom are readily to be distinguished. The weevil soon finds out these; and selecting a blossom every way to her mind, commences her operations. The beak or trunk, before alluded to, is furnished at its extremity with short teeth, or mandibles: with these she gnaws a very minute hole into the calyx of the future blossom, and continues gnawing until the trunk is plunged in up to her eyes; the trunk is then withdrawn, and the hole examined with careful scrutiny by the introduction of one of her feelers, or outer prongs of her trident. If it seem to require any alteration, the trunk goes to work again, and again the feelers: at last, being fully satisfied that the work is well accomplished, she turns about, and standing with the extremity of her abdomen over the hole, thrusts into it her long ovipositor, an instrument composed of a set of tubes retractile one within the other, and deposits a single egg (never more) in the very centre of the future flower. Another examination with her feelers now takes place; and when she is thoroughly satisfied that all is right, away she flies to perform the same operation again and again, never tiring while she has an egg to lay.

The bud continues to grow like the other buds; the little perforation becomes invisible. By and by the egg bursts, and out comes a little, white maggot, with neither legs nor wings; this maggot, directly it is hatched, begins to devour the young and tender stamens; next to these the style is attacked, and eaten down to the fruit, the upper part of which is quickly consumed: the maggot is then full fed; it casts its skin, becomes a chrysalis, and lies 
perfectly still. $U p$ to this time the blossom has continued healthy, no trace of the enemy being to be discovered without; but when the neighbouring blossoms are expanding their petals to the genial breath of spring, those of the mutilated bud remain closed, and retain the arched, balloon-like appearance of a bud about to burst.* For a few days they preserve their lovely pink colour ; and then, by degrees, fade to dingy brown. In this state they remain until the other apples are well knit; and then the damaged blossoms, by their decided contrast, appear very conspicuous. On opening these brown, or rather rust-coloured blossoms between the 10th and the 15th of June, the chrysalis will be found to have changed to a perfect beetle, similar to its parent above described, which, had it been left to itself, would in a few days have eaten its way through the weather-beaten case of dried petals, and left its prison-house, flying about to take its pleasure, until the chilly winds of autumn should drive it to its winter habitation under the bark: and in the next spring, the whole round of operations through which we have watched its parent and itself would be performed with the same unvarying, unerring instinct. The cloudy, misty, east wind, in which our farmers and gardeners see the blight, is the very weather of all least favourable to the propagation and increase of these weevils. The fine, clear, sunny days of March and April are the most favourable to them. The

* Within this balloon, as the writer terms it, I have often found a small species of Cimex in company with the beetle or its chrysalis: I have never been able to detect any aperture through which the Cimex could have entered, and although $I$ have been altogether unable to discover any connexion between the Curculio and the Cimex, or even to form a conjecture as to the cause of their companionship, I cannot for a moment doubt that the welfare of one is in some measure dependaut on the other.-E. $N$. 
tom-tits, sparrows, bullfinches, and other birds, which, at this time of year more particularly, frequent our orchards and gardens, and which also, at this time of year, are persecuted with relentless hostility by the farmer and gardener, live, during these months, solely on these weevils, and similar little insects, and consequently are the only check on their increase that we possess; so that, in our investigations of blight, we see how a little prejudice, superstition and ignorance tend to increase the injury they dread.

A third and still more formidable enemy of the cider orchard is the APpLE Mотн; $*$ it is a beautiful little creature, its wings are studded with silvery shining specks, as though they were inlaid with precious gems. It is the most beautiful of the beautiful tribe to which it belongs, yet from its habits not being known, it is seldom seen in the moth state, and the apple-grower knows no more than the man in the moon to what cause he is indebted for his basketfuls of worm-eaten windfalls in the stillest weather. To find the moth in the day-time, the trunks of the appletrees should be carefully looked over ; or if your orchard be surrounded by a wooden fence, the moth may often be found sitting against it, with its pretty wings neatly folded round its body. Towards evening, in fact, at sunset, it begins to move, and may then be seen hovering about the little apples, which, by the time the moth leaves the chrysalis, the middle of June, are well knit, and consequently fit for the reception of the eggs, which it lays in the eyes, one only in each, by introducing its long ovipositor

* Tortrix pomonana of authors: I am inclined to believe that many nearly allied species have very similar habits to those which are here described.E. N. 
between the leaves of the calyx, which form a tent above it that effectually shields it from the inclemency of the weather, or any other casualty. As soon as the egg hatches, the little grub gnaws a hole in the crown of the apple, and soon buries itself in its substance; and it is worthy of remark that the rind of the apple, as if to afford every facility to the destroyer, is thimner here than in any other part, and consequently more easily pierced. The apple most commonly attacked is the codling, a large, early sort, which ripens in July and August.

The grub, controlled by an unvarying instinct, eats into the apple obliquely downwards, and by thus avoiding the core and pips in no way hinders its growth: at first it makes but slow progress, being little bigger than a thread, but after a fortnight its size and operations have much increased; it has now eaten half way down the apple, and the position of the hole at the top, if the apple continue upright, or nearly so, is inconvenient for a purpose it has up to this time been used for, that is, as a pass to get rid of its little pellets of excrement, which are something like fine saw-dust or coarse sand; another communication with the outer air is therefore required, and it must be so constructed as to allow the power of gravity to assist in keeping it clear; it is accordingly made directly downwards towards that part of the apple which is lowest, and thus the trouble of thrusting the pellets upwards through the eye of the apple is saved, and a constant admission given to a supply of air without any labour. The hole now made is not, however, sufficiently open for an observer to gain by its means any knowledge of what is going on within ; this is only to be obtained by cutting open a number of the apples as they gradually advance towards ripe- 
ness; the hole is, however, very easily seen, from its always having adhering to it on the outside an accumulation of little grains which have been thrust through. Having completed this work the grub returns towards the centre of the apple, where he feeds at his ease. When within a few days of being full-fed, he for the first time enters the core through a round hole gnawed in the hard, horny substance which always separates the pips from the pulp of the fruit, and the destroyer now finds himself in that spacious chamber which codlings in particular always have in their centre. From this time he eats only the pips, never again tasting the more common pulp which hitherto had satisfied his unsophisticated palate: now nothing less than the highly-flavoured, aromatic kernels will suit his tooth, and on these for a few days he feasts in luxury.

Somehow or other, the pips of an apple are connected with its growth, as the heart of an animal with its life; injure the heart, an animal dies: injure the pips, an apple falls. Whether the fall of his house gives the tenant warning to quit, I cannot say, but quit he does, and that almost immediately; he leaves the core, crawls along his breathing and clearing-out gallery, the mouth of which, before nearly closed, he now gnaws into a smooth, round hole, which will permit him free passage without hurting his fat, soft, round body; then out he comes, and for the first time in his life finds himself in the open air. He now wanders about on the ground till he finds the stem of a tree: up this he climbs, and hides himself in some nice little crack in the bark.* I should remark, that the fall of

* A talented entomologist assures me that the species pomonanus frequently buries itself in the ground, after the manner of the larger species of nocturnal Lepidoptera.-E. $\boldsymbol{N}$. 
the apple, the exit of the grub, and his wandering to this place of security, usually take place in the night time. In this situation he remains without stirring for a day or two, as if to rest himself after the uncommon fatigue of a two yards' march; he then gnaws away the bark a little in order to get further in out of the way of observation; and having made a smooth chamber big enough for his wants, he spins a beautiful, little, milk-white, silken case, in which, after a few weeks, he becomes a chrysalis, and in this state remains throughout the winter and until the following June, unless some unlucky, black-headed tit, running up the trunk, peeping into every cranny, and whistling out his merry see-saw, happen to spy him, in which case he is plucked without ceremony from his retreat, and his last moments are spent in the bird's crop; but supposing no such ill-fortune betide him, by the middle of June he is again on the wing, and hovering round the young apples on a midsummer evening as before.

By burning weeds in your gardens at this time of year you will effectually drive away this little moth. If you have trees the crops of which you value, make a smoking (mind, not a blazing) fire under each; it will put you to some inconvenience if your garden be near your house, but the apples will repay you for that.

Who has not noticed the white-thorn hedges stripped of their leaves, and the twigs matted together with a web? and who has not heard the appearance attributed to east wind and to blight? The blight is nothing more than the caterpillar of a small moth, the Little Ermine Moth,* which lays its eggs on the twigs the year before. When

* Yponomeuta padella.-E. $N$. 
these eggs are hatched, the little caterpillars which come out of them, feed for a few days on the pulpy, internal part of the leaves, but soon set about spinning for themselves a nice, silken, spacious house, taking care to enclose two or three leaves; as soon as these leaves are devoured, for which purpose they are enclosed, the house is enlarged, and made to include other leaves; these, in turn, are devoured, and others enclosed, till a mass of web is formed as big as one's head. These masses are often so abundant as to touch one another, and the whole hedge looks as though it were dead, not a leaf or a fragment of a leaf being visible. The caterpillar is a little, blue-black fellow, with a row of jet-black spots down each side; and when you hunt him out of his web, he wriggles away backwards and drops, spinning a thread as he falls, and suspended by this thread, he hangs with all the ease of a spider; swinging backwards and forwards with the wind as unconcerned as if still under cover of his silken domicile: but there is this difference between the caterpillar and the spider; the caterpillar spins his thread from his mouth, the spider from his tail. When full fed, the caterpillars fasten themselves by their hind legs to a part of their web, and, hanging with the head downwards, turn into chrysalises. I have often found dozens hanging together in a line, like rabbits on a pole. At the end of June the moth appears; it is a pretty little creature, having wings of a leaden ground-colour, with jet-black spots, but varies, some specimens having a pure white ground. Last year, our hedges about Farncomb were swarming with them: and on gates, under the coping of stone walls, and all such places, you might have found the chrysalises hanging by thousands. 
A larger moth, with a yellow tail and snow-white body and wings, is also very destructive to white-thorn hedges; but its proceedings have already been so accurately told, that I will not repeat them. This moth is appropriately called the "YeLLOW-TAIL." * A kind very similar in its ways to the little ermine moth inhabits the oaks, and sometimes in such swarms as to consume every leaf, and incase all the twigs in a continuous web for hundreds of acres; I have noticed this in Surrey and Sussex on three occasions, and once in part of Shropshire and Herefordshire. In the July of 1831 the oak-woods about Downton Castle, the residence of the late Mr. Knight, the celebrated horticulturist, were as completely bare as on Christmas-day, and had a most unnatural appearance; the season was rather late, and the moth was then in the chrysalis, as I ascertained by climbing up some of the trees, and shaking down whole showers of them. Early in the year the caterpillars may be seen, when the sun is warm, hanging by their litthe threads from all parts of almost every oak tree, swinging to and fro with the least breath of air, like a lot of pendulums, each varying in time according to the length of its thread, which acts as the rod, and each occasionally giving itself a twist, like a slack-rope dancer, in the overflowing joy and happiness of its little heart. Each turns to a black chrysalis; and in ten days afterwards to a beantiful, yes, exceedingly beautiful, pea-green, bell-shaped little moth, $\uparrow$ but too common to be valued for its beauty. When the moth is on the wing the oaks again clothe themselves with all the firesh green of spring, and the woods once more throw off their wintry looks. 
There will perhaps be some who ask the use of all this : who want to know why the blights are to be brought out of their hiding-places and hauled over and written into notice: who will tell you that the oaks and the quicksets have lived on through all their trouble, and despite the attacks of all their enemies: the teetotallers, too, will doubtless turn up their noses and gravely assert that if all the hops and all the apples were destroyed by vermin it would be a good job, because it would stop the supplies of beer and cider: others may contend that the evil done is accompanied by good: for example, that the ravages of the hop-fly keep up the price of the hop, so as to afford a tolerable profit to the grower; whereas, were there to be no fly, the crop would be larger than the consumption, and the price consequently not a remunerating one. By the way, I well recollect, that after the immense crop of 1826, the price did not repay the grower his rent, taxes and labour: and the farmers, a set of men, I am sorry to say it, with less forethought generally than any other class of tradesmen, most improvidently went to work and were silly enough to grub up their hop-yards and sow wheat. This took place in several instances in the district between Farnham and Alton, and at the same time both in Kent and Herefordshire; and afterwards, when the price recovered, some of the finest pasture land in the world was ploughed up to make hop-yards, which have not yet paid even the tithe. There is, however, a blight whose ravages are without any proportionate good, or any good at all that I am aware of : a thief that robs our sheep and our cows of their winter food, and often compels their owners to starve them to skin and bone, thereby causing murrain and all manner of disease to the kine, empty pockets to 
themselves, and a host of accompanying evils; and this thief is a little, glossy, tiny, skipping, hopping, merry-andrew kind of a beetle, in common parlance known by a name the very mention of which elongates a farmer's countenance at least an inch and a half-the TurNip-FLY.

The turnip-fly is not always of one kind, but the difference between them is not important, they only alter in their colour, their shape is always alike: the most common is coloured bottle-green; but in some fields all are black, with a whitish line or stripe from stem to stern on each side down the back; * they are so active, that the only way I could ever obtain them in the newly-sown fields was by sweeping the surface with a gauze net on an iron hoop at the end of a strongish stick; they jump like fleas directly they see you. These beetles begin their attack on the turnip directly it is up, devouring the two cotyledons and the little heart, and sometimes, in a few days leaving the field as brown as the day it was sowed. $\dagger$

* The striped beetle, Altica nemorum, is properly the turnip-fly: the green one is A. Brassicæ.-E. $N$.

+ To Mr. Le Keux is due the credit of discovering (or at any rate of publishing an account of) the economy of the turnip-beetlc. "Having witnessed the destructive effects of the turnip-fly in the year 1830, whilst lodging at a farm-house in Devonshire, I was led to observe its habits, and to try many experiments, in the hope of being able to find some means of guarding against its attacks. My first observations were made upon a field of about eight acres, forming the apex of a lill, which was sown with turnips. When the young plants were just rising above the ground, the wind was in the south-east, and continued to blow from that point for more than a week, carrying in its course the scent of the turnips over the fields lying to the north-west, and the turnips on the nortli-west side of the field were so destroyed by the fly that nearly an acre was quite bare, whilst the south-east side was not attacked in any perceptible degree until after the plants had attained to sucli a size as not to be much injured by their depredations. This circumstance led me to conclude that the fly had heen attracted by the scent, which subsequent observations have confirmed. When I became familiar with the form and character of the insect, I 


\section{Schemes out of number have been tried to get rid of or kill this little pest wherever it has appeared, the particulars}

very soon found that its locality was not confined to turnip-fields, but that it was to be met with in grass lands which had not been ploughed for many years, and where no turnips were to be found within half a mile. I have since found them in abundance in dry situations in all grass lands where I lave taken the trouble to search for them. Although I found the insect in such abundance, I was unsuccessful in my endeavours to discover its mode of breeding until after five years, when a small piece of land (the upper part of a field sown with barley) in a sheltered situation with a south aspect, and which had been well dressed with lime, was sown, early in May, with white stone turnips for the table, but they no sooner appeared above ground than they were destroyed by the fly; it was then sown again and harrowed, and the surface thickly strewed over with wood ashes, but the plants were again devoured as rapidly as before, and not more than a dozen acquired the rough leaf, and a few of these survived till the leaves grew to be six or seven inches in length, but they were perforated in every part. Upon examining one of these leaves (a portion of which, preserved dry, I send with this paper) against the light with a magnifying glass, I perceived a larva between the upper aud under surface, a careful inspection of which led me to think it the larva of a beetle, and probably of the one I had been so long in search of. I hastened back to the field, and carefully removed the earth around the plant from which the leaf had been taken, and there had the satisfaction to find specimens of the larvæ and pupæ.

"I had previously endeavoured to breed them, by keeping a number confined in a small box covered with wire gauze, but as I could in this way only feed them by dropping in fresh bits of turnip-leaf daily, I did not succeed in my object, although the insects appeared healthy, and I kept them alive in this manner from July until February in the following year. The reason of my failure is now sufficiently obvious, since it is necessary that the leaf should be in a growing state, otherwise the eggs which are laid upon it shrivel up when the leaf becomes dry. Being still at fault as to the origin of the larvæ, I captured ten males and ten females in pairs, and inclosed them in a glass tube covered at each end with wire gauze, into which I introduced a single leaf of turnip, with water to keep it fresh; by this means I was enabled to examine the insects and leaf on all sides with a magnifying glass at any time without disturbing them. Having, previous to introducing the leaf, ascertained, with a strong magnifyer, that there were no eggs or larvæ upon it, on the following day I had the satisfaction to perceive five small, smooth, oval-shaped eggs adhering to the underside of the leaf, and so nearly resembling it in colour that I was no longer 


\section{of which, if I were to relate, with the accompaniment which I must add that they have all turned out to be failures,}

surprised that they should hitherto have escaped my observation. This leaf was removed with the eggs upon it and placed in water, and its place supplied by a fresh one, which, on the following day, had three eggs upon it, and the third leaf four eggs, each of which leaves was placed separately in water. The forrth leaf I suffered to remain with the insects a week, supplying it with fresh water daily, and at the end of that time it had thirty-one eggs upon it. In two other glass tubes I confined single pairs of insects, with a leaf in each, upon which I never found more than a single egg deposited on the same day, and in those leaves taken from the field with larvæ in them (some containing six) no two of them were of the same growth. I found great difficulty in preserving the leaves during the length of time necessary for the hatching of the eggs, and as it would have been impossible to have preserved them long enough for the feeding of the larvæ, I began to despair of success, until I observed that in those leaves taken with larvæ in them from the field, it was not uncommon for the larva to leave the burrow it had first commenced, and travelling (which, from its formation I had supposed it incapable of doing) to a distant part of the leaf, form a new one. About the time, therefore, when I expected the eggs to hatch, I placed fresh leaves by the side of the old ones, to which the young larræ soon found their way, and lodged themselves. The egg hatches in ten days from the time it is laid, and the larva immediately begins to eat its way into the leaf, and form a burrow by feeding upon the pulp between the upper and under surface of the leaf, which, however, is not easily perceptible to the eye unless held up against the light, although the track is sufficiently obvious after the larva has left it, and it has become dry. The larva is full fed, and goes into the earth at the end of sixteen days, burying itself about an inch and a half below the surface, and in such a situation, that the turnip leaf above may afford shelter in case of rain. I have reason to believe that it remains in the earth about a fortnight before changing into the perfect beetle. Some of the first specimens of larvæ and pupæ which I took in the field, I placed in finely pulverized and very dry earth, and in a few days they were shrivelled up; the others I also put into fine earth and saturated it with water. Unfortunately there was no opening at the bottom of the cup ; and the next day, perceiving that the earth was still saturated with water, I drained it and removed the larvæ, but they were all dead; this accident may serve to account for the scarcity of the insects after very wet seasons. I have been equally unfortunate in my last attempt to ascertain the precise time between the larva and the perfect insect, for I covered the earth in which $I$ had placed them so closely, on account of their small size, to prevent them from 
would not, I fancy, be of much use: but I one day was cogitating on the matter, and argued to myself thus: it would be a difficult task to catch and kill twenty thousand fleas if shut up in a room with them; but it might not be quite so difficult to prevent twenty thousand fleas coming into a room where there were none previously; and the wisest way seemed to me to find out how they could come there. Now, as all straight-forward inquiries of this kind are langhed at, and at once yclept theories, I kept all my operations to myself, and now, for the first time, offer them to the public. I am very sorry to say they are yet incomplete, but still they will be found of some use to those who are disposed to pursue the subject.

After I had made the acquaintance of these fellows so thoroughly that I knew them whenever I met them, I amused myself by sweeping the hedge-rows with a gauze net fixed on an iron hoop, and this hoop screwed to the top of a stout walking-stick. These hedge-rows require a word or two: they are generally huge embankments thrown up like the fortifications of the ancient Britons, and on one side there is commonly a deep trench, making the simile still more complete: on the top are antiquated specimens of hazel, oak, maple and whitethorn, occasionally chopped down to hedge measurement; and high above these a consumptive elm may here and there be seen rearing its naked and ugly stem. The sides or banks of these

escaping unobserved, that the earth became mouldy, and they were all destroyed; but I have a great many specimens of the beetle produced from larvæ which I fed and placed in a garden pot enclosed in a cage of fine wire gauze, but they being introduced at various times as they became full fed, I could not ascertain the precise time of any individual specimen.-Trans, of Ent. Soc. of London, ii. 24. 
hedge-rows are composed of a luxuriant mass of charlock, white mustard, hedge garlick, docks, thistles and kecks. In such spots I exercised my sweeping-net, and here I found the turnip-beetle in swarms, both kinds of them, and principally on the charlock and mustard. I found that these hedge-rows all through the spring and early summer are regular preserves of the turnip-beetles: here they have the most comfortable housing that could possibly be provided; here they fulfil the command, "increase and multiply ;" here they congregate without fear of molestation; here, in fact, they may be said to be preserved, strictly preserved, as the bigger pests called game are preserved in other places. Well! when the hedges are thoroughly rank with weeds, and the weeds well stocked with turnipbeetles, the farmer sets to work and sows his turnips : if the weather is kind they come up directly, and the land is soon seen to be sprinkled all over with the young and tender crop. It must be known to every observer - I was just going to write farmer, but I believe farmers observe nothing but fair-days and market-days - it must, I say, be known to every observer, that the turnips come up with two seed-leaves, more juicy, tender and fleshy than any they afterwards send forth, and also very different in shape and appearance; well, these seed-leaves of the turnip are the very choicest food of the turnip-beetle: as buckwheat sown around the pheasant preserves brings the pheasants from their cover, so do the seedling turnips bring these little skipping beetles from the preserves which the farmers provide for them. The turnip-beetle not only runs and jumps with activity, but flies with the greatest ease; and just at that warm time when the turnips are coming up; in those sunny, balmy days, the turnip-beetles and a hun- 
dred other kinds of all sorts and sizes, set out on their foraging excursions. The air is filled with them: if you ride outside a coach, they are eternally knocking against your physiognomy : if you work in your garden, you hear them rattling, like a gentle shower of rain, on the lights of your cucumber-frame: no earthly power can keep these little miscreants from roving on a bright summer day. Then comes another fact: all insects are gifted with a wonderful sense of smell-vast power in the olfactories: it may be presumed that the odoriferous particles borne on the wings of Zephyr from a field of delicately young turnips, their very favourite food, would be most attractive to them; and such is the case: the fine weather tempts them to leave the preserve, the scent of the turnips lures them to the fields, leads them by the nose, and you may see them descending during the hours of sunshine, in a gentle, continuous and disastrous shower. The work of destruction is brief, but complete; like locusts they clear the ground as they proceed; beginning on the lee-side of a field they march forward, making destruction sure. I have seen three and four on a single seedling; each with his head buried in the hole he has just begun to gnaw. If the spring has been fine and the weather at this period is dry, there is no hope for the crop : its fate is sealed : if, on the contrary, the weather is wet, there is every chance of the crop being saved. The marauders cannot bear the wet, and the plants are too small to afford them shelter beneath the leaves, so they creep under ground, hiding beneath little lumps of earth, and there remain till all is dry again: meanwhile the turnip grows apace, sends out its rough leaves, gains strength and bulk hour after hour, and soon supplies more food than the beetles can consume; so that 
when the hot sun again entices the beetles from their hiding-places, there is not only a plentiful supply for them, but a supply greater than they can consume, so that they may satisfy their cravings, however great, and still leave enough for the farmer's requirings; for it must be observed, that the seed that is sown and the plants that come up in favourable seasons, are as ten to one of the number eventually suffered to arrive at maturity: if their insect enemies spare them, a great part are sure to fall by the hoe, in order that those which remain may grow to a bigger size.

But suppose the weather to be hot and dry, what is your remedy then? Experience having taught me that insects abominate smoke, and are killed by the fumes of sulphur, I endeavoured to bring this experience to bear on the turnip-beetle, and found it most successful. But to revert to the huge embankments or preserves, I would begin by reducing the magnitude and number of these : where practicable, I would throw the whole space occupied by them into the field: where there existed an absolute necessity for a division or fence, I would reduce it to the smallest dimensions that would answer the purpose : having reduced the fences to the minimum of size actually required, I would clear them from the charlock, mustard, dock, thistles and kecks,* and instead of allowing these plants to seed I would gather them in heaps along the hedge-rows, and watching my opportunity of fine, sunny weather, I would fire these heaps day after day, when the beetles were on the wing, casting a pinch of flour of sulphur on each of them. The gain of land would repay

* For some account of the Botany of Godalming, see Appendix A. 
tenfold the labour of the few women required to weed: the weeds themselves would be the only fuel required, and five shillings' worth of sulphur would be enough for a good sized farm. Another fact, which to me is very obvious, although most farmers deny it, is, that swedes are much less injured by the fly than any other variety of turnip whatsoever, so that I would recommend the cultivation of this plant where practicable in preference to any other. One more partial remedy is worthy of notice : the turnipbeetle has a great antipathy to the taste of salt, and if the leaves are watered with a weak solution of salt in water I have found them quite untouched. Great benefit also follows the steeping of the seed in weak brine; this I once proposed in the belief that the eggs of the parent beetle were laid on the seed, an error I immediately afterwards detected and publicly renounced: the egg I found laid on the leaf itself.

A second, but still more dreaded plague of the turnip crop is the Nigger : happily, however, its visits are few and far between. This year [1835] all our turnips are infested with these niggers. They are the caterpillars of a fly that ought really to be called the turnip-fly, a name which we have seen is universally given to the turnip-beetle. About the middle of July these real turnipflies were showered down on us as it were from the clouds; they fell thicker than rain-drops, and hovered about the turnips in such myriads that whole fields were coloured with a rainbowy tinge when the hot sun shone on their filmy wings. I will give an entomological description of one of these flies : the head and antennæ are coal-black; the thorax is yellow before and on the top, but coal-black on the sides and behind; the body is yellow; the wings 
are clear and very shining, and tinged with yellow, and the upper ones have a dash of coal-black along the upper margin, which reaches three quarters of the way from the thorax to the tip of the wing; the legs are yellow, spotted with black.* These flies do not taste the turnips, but only come to them on family business : they deposit their eggs on the under side of the leaf, gluing them on the cuticle, as already described in the instance of the gooseberry-grub. In a very few days they were hatched; from the eggs had emerged the little caterpillars. On the 9th of August these little creatures swarmed on every leaf. I walked over field after field, and found them all in the same state. On Mr. Moline's farm, at Old Pond, three men were hoeing the turnips on a Saturday: I showed them the enemy, and told them that the turnips would be thin enough by Monday, without any hoeing; however, they were farmers' men, and "knowed better." On Sunday I could not get out as far as a turnip-field. On Monday I was again

* This iusect is the Tenthredo centifoliæ of Panzer, and was known as the parent of the nigger caterpillar even to Fabricius, who says "Larva tota nigra victitat in Brassica Rapa quam destruit." But perhaps the most remarkable fact in its published history is that a Norfolk farmer, a Mr. Marshall, connected the yellow fly with the nigger or canker, in a paper in the "Transactions of the Royal Society' for 1783. This author supposes that the fly is not a native of this country, but comes from beyond the sea, as it was said to have been observed by fishermen on the coast in "cloud-like flights." See Appendix B. After the date of the letter reprinted in the text, viz., August 15, 1835, our entomologists took up the subject with great zeal, and wrote about it in various papers, periodicals or Transactions, or made verbal communications at the rooms of the Entomological Society and elsewhere; in fact the nigger was the same fruitful subject to entomologists in 1836, that the potato-blight became to botanists nine or ten years later: and I regret to say that the entomologists, like the botanists, left their subject very much as they found it. The nigger disappeared the following year, and the advice volunteered for its extermination was neglected, and has since been completely forgotten.-E. $N$. 
in the field at Old Pond, and the turnips were not. Since my last visit they had been swept from the face of the earth. The land was everywhere as bare as on the day it had been sowed. There was no speck of green for the eye to rest on. It was a wild and universal desolation; and the black, crawling vermin that had caused the ruin were clustered in bunches on the ground, or lingering about the skeletons of the turnip-leaves. No plague of Egypt could have been more effective : the mischief was complete. Some fields received the blast a few days later than others, but all had it: not one escaped, unless the crop were swedes, and it is remarkable that these were untouched. I will now give a somewhat more particular history of this blight. The egg is of an oblong form and pale colour, and is so firmly glued to the cuticle of the leaf, that I have never been able to get one off without breaking it, but when the egg is removed it leaves, or rather discloses a wound in the cuticle of the leaf, and I have litthe doubt that this wound is made by the parent fly, in order that the egg itself may receive nourishment from the juices of the plant : this is perhaps a little hypothetical, but there is a fact which seems to require such an explanation, for the egg positively grows while still to all appearance an egg. At the end of four days its bulk is nearly doubled, and by the ninth day, when the grub comes out, it is actually three times as large as when deposited. Directly the young nigger is let out of the eggshell he begins eating away in right earnest ; the first onslaught is generally made as near as possible to the spot where he was born, but after a day or two the edges of the leaf seem to be most favoured by his attentions, and here the whole family may be seen working with a will, 
their heads at the work of demolition, and their tails cocked up in the air. In an incredibly short space of time the green of the leaf is gone, and nothing is visible but the naked skeletons of veins, which the niggers do not choose to consume. The colour of the grub is a dull lead-colour, with a rather rough or wrinkly skin, but without hairs, and down each side, from stem to stern, is a paler line; its

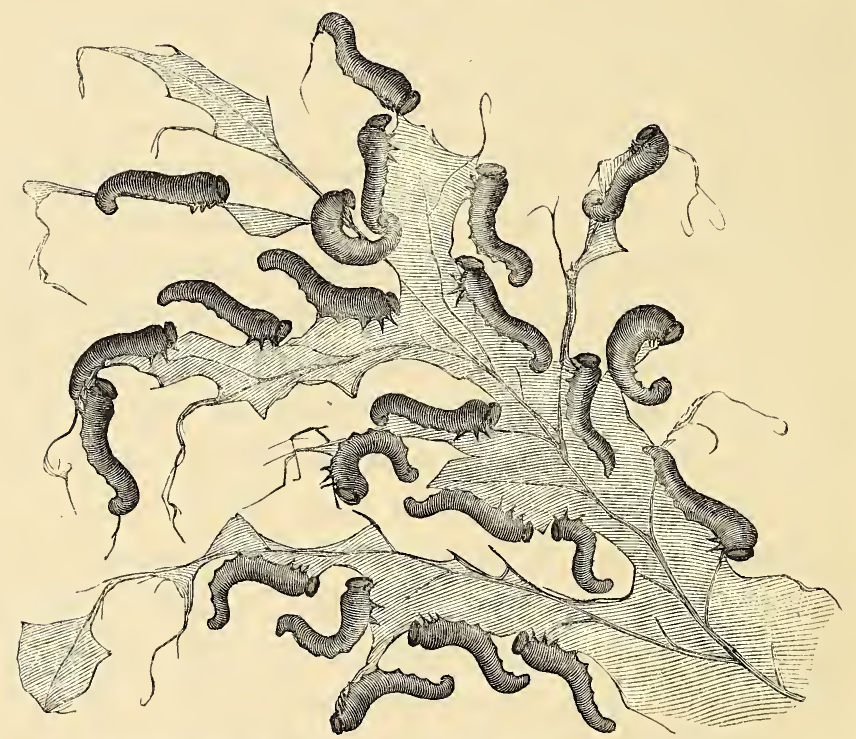

THE TURNIP-NIGGERS OF THE NATURAL SIZE.

length, when full grown, is between half and three quarters of an inch ; it has no less than twenty legs, six of which are placed in three pairs, very near the head. These six are long, hard, horny and sharp-pointed, and with them the grub holds fast the edge of the leaf while he goes on devouring it: the other fourteen legs are arranged in seven pairs along the body, and are soft and 
fleshy, without any horny substance, and quite without sharp points. These legs are used when the grub is crawling; but while he is eating, and the tail, indeed the greater part of the body, is, as I have already said, cocked up in the air, they are quite unemployed. Sometimes, and especially when offended or in danger, the nigger-grub coils himself up in a ring, holding the leaf very slightly by the first pair of legs, that pair next the head, and when touched in this state falls directly to the ground, and there lies as though dead ; indeed, if not in a ring before, he almost always rolls himself into one when touched. When the nigger has reached his full size, a period depending on the temperature of the weather and the supply of food, but averaging at twenty days, he burrows in the earth, and there makes a little oval house, just big enough for his body, which has all at once become shorter and thicker: he then plasters the walls of this place with a sort of sticky varnish or glue, which he discharges at this time only: he keeps on discharging and spreading this glue till he is quite surrounded with a strong, tough, and hard cocoon, the particles of earth being mixed with the glue, and the whole forming an admirable and perfect defence against wet or the attacks of insects. The period of his stay in this cocoon varies according to circumstances; if the weather is hot, it sometimes happens that the grub becomes a mummy-like chrysalis in ten days, and a perfect fly and again on the wing in five more; but the greater part of the brood remain unchanged all through the autumn, winter and spring. I have turned up the cocoons, and found the grub little altered even in May. Soon after this the change to a chrysalis must take place, and the change to a fly occurs, in average seasons, about 
the middle of July: when this is accomplished it moistens one end of its cocoon, so as to make it easy to come out, and then it climbs up through the earth and takes wing. But the plough and harrow, the operations of which are sure to follow the eating off of the turnip-crop, often turn up and expose the cocoons, so that instead of being an inch or two below the surface they are laid at the top. The system of crop rotation, however, serves to remove the fly of the nigger from the food best fitted for its progeny, and it often happens that the flies come to maturity in a field of ripening grain, the ears of which they mount, and spreading their wings, float off in myriads to the nearest turnip-field.

I find a hundred recipes for the destruction of these niggers, all of which are moonshine, except one, and this for a wonder is rational. It is this : buy an immense number of ducks, and turn them into your turnips, and they will devour the niggers by millions, and in a few days become as fat as butter. Thus two birds are killed with one stone, the ducks fatted and the turnips saved. When we get on a little farther with our inquiries into the history of animals, especially such little things as insects, you may depend upon it, we shall find the best way to check the increase of any hurtful kind, is to encourage any other animal, whether beast, bird, fish or insect, that makes the injurious one its prey. You see Providence has foreseen that the earth might at any time be desolated, or totally unpeopled, by the natural increase of many kinds of animals, and $\mathrm{He}$ has provided against it. The tiger-moth caterpillar nearly every year is produced in these islands in sufficient numbers to eat up every green leaf or blade of grass; to starve all our sheep, cows and horses; and so to 
deprive us of both animal and vegetable food. This caterpillar eats almost everything. Well! of all caterpillars this has the most insect-enemies, or parasites, so many, indeed, that not more than one egg out of fifty thousand produces a moth; thus its voracity and its productiveness are rendered harmless. You will laugh when I tell you that I breed lady-birds purposely to destroy plant-lice; but that is really the case, and it answers capitally. The niggers have many natural enemies besides ducks; some of these enemies I have found out. Frogs and toads prefer them to almost all other food, and will gorge themselves to such an extent that they can hardly leap or hop: then there is a hairy, disagreeable-looking fly, which rides on the nigger till it can lay an egg on its back. This egg in one day becomes a maggot, eats into the flesh of the nigger, and going with it into the ground, it allows the nigger to make its cocoon, then eats up all its entrails, leaving it a mere skin, and within this nigger-skin it changes to a chrysalis, and finally to a fly. But it would be difficult to find enough frogs or toads or flies to effect a cure : ducks, therefore, are the best remedy, except, indeed, that I fear the demand for ducks would be greater than the supply; but a farmer, especially if he has water, ought to keep an immensity of ducks; they are always useful, and eat up lots of slugs and other vermin: moreover, they never scratch, like fowls, and are always saleable at a paying price.

The turnip has three other insect enemies: the worst of these is a weevil, a little, black beetle, with a trident, like that of the apple-weevil, but the operations of the TUrnIPWeEvil are quite on a different plan: the eggs of this little fellow are laid on that part of the bulb of the turnip 
which is above the ground, and the grub which comes from it eats into the rind of the turnip, making it hump up in warts and all manner of rugosities, and causing the whole bulb to become woolly, and distasteful to sheep and cows. This little and most insidious enemy has escaped the notice both of naturalists and farmers, first, because it is so small, and secondly, because its ravages do not cause any diminution in the quantity of either the leaf or bulb. The caterpillar of a large moth, which may be called the Turnip-Moth, does the crop an incredible injury in some seasons, by eating the crown of the plant just where the leaves grow out from the bulb : this it does only in the night, living in a burrow of its own by day. This caterpillar is the more injurious because its labours begin after the turnips have been finally thinned out by hoeing, and each left at the exact distance from the rest which it is designed to occupy. I know of no remedy. Lastly, the TurnipApHis. There is no plant without its plant-louse or Aphis, and the turnip is no exception to the general rule. This is, however, the least troublesome of its enemies ; for the plant-lice attack the turnip when in full vigour and make but little impression on it.

Plant-lice, I have said, are everywhere. I have to-day, [August 15, 1835], cut open codling after codling, and found the pips garrisoned with them; not one lone Aphis, but a whole troop, of all sizes. When I let in the daylight there was a considerable sprawling and waving of legs, and no small alarm in the hive, but by degrees they got used to light and fresh air, and were quite still. I tried to tickle them with a straw, in order again to watch their movements; when lo and behold, they were all dead, - gathered to their fathers,-gone to the tomb of all the 
Capulets! Some had heaved anchor and dropped from the pip ; others fixed more firmly had died at their post, and tucking their legs together under them, hung by their beak. In no apple was there any road in or out; there was no chance of their passing to the outer air, or of their having come from it; indeed their speedy death proved that change of air did not agree with them. I was particularly careful in my search for a via, but there was none. I have often seen the same thing in a bloated poplar-leaf; but here is a possibility of the egg being laid between the cuticles of the leaf, then, the sap-suction commencing, the bloat may be caused ; but this is impossible in a huge apple, with an inch and a half of pulp in every direction. I am unable to explain the mystery; so, like many other wiseacres, I content myself with wondering how, in the name of fortune, the Aphides got there!

Another odd station for Aphides is on the roots of plants. I have found them by hundreds on a thistle-root, closely packed together, and almost as white as snow. The other day I pulled up a large thistle that grew on an anthill, and thus I brought to light a whole colony of these white Aphides. I had long known of the great value which ants set on these little beasts, so I shook down some dozens of them from the thistle-root, among the ants, which were all a-swarm at the damage I had done to their dwelling. No sooner were the ants aware of the presence of the Aphides than they began to fondle them with their legs - sometimes positively taking them round the neck - to tap them on the back with their antennæ, and to lick them with their tongues; they then took hold of them with their jaws, and lifted them from the ground, and carried them with the greatest care, one by one, into the recesses of the 
nest. I walked by the same way about three hours afterwards, and found the nest all quiet and orderly, and not an Aphis was to be seen; so I went to work with my knife, and scraped down the side of the hill. I soon came to the Aphides; they were clustered together on little bits of thistle-root, which had been broken off in the ground, and were attended by numbers of ants. When the ants found their cattle were again in jeopardy, they drew them gently from the root, and carried them still farther into the nest.

I am quite convinced that honey-dew is a secretion from the Aphides, and that ants devour this honey-dew, and a sweet, clear, liquid honey it is. I have often watched an ant go from one Aphis to another, stand behind each, and gently squeeze the body with its fore legs; perhaps one Aphis in ten, not more, will give out a small drop of honey, as clear as crystal, which the ants instantly swallow. The ants take much more care of the Aphides than the Aphides do of themselves: they are sad, dull, stupid creatures. It is very pretty to see the licking and washing and cleaning and caressing which the ants constantly be-stow on them. When the Aphides cast their skin, the ants instantly carry it away, nor will they let any dirt or rubbish remain among them or on them. But the most amusing care of the ant is guarding the Aphides from the attacks of that little parasitic fly, whose operations $\mathrm{Mr}$. Haliday has so well described. You must have seen a sheep-dog run over the backs of a whole flock of sheep, when closely crowded together, in order to bring back some simer that has gone astray; so will the ants in the hot sunshine run about over an establishment of Aphides, driving away the-rascally parasite that is for ever hovering over to destroy them. 


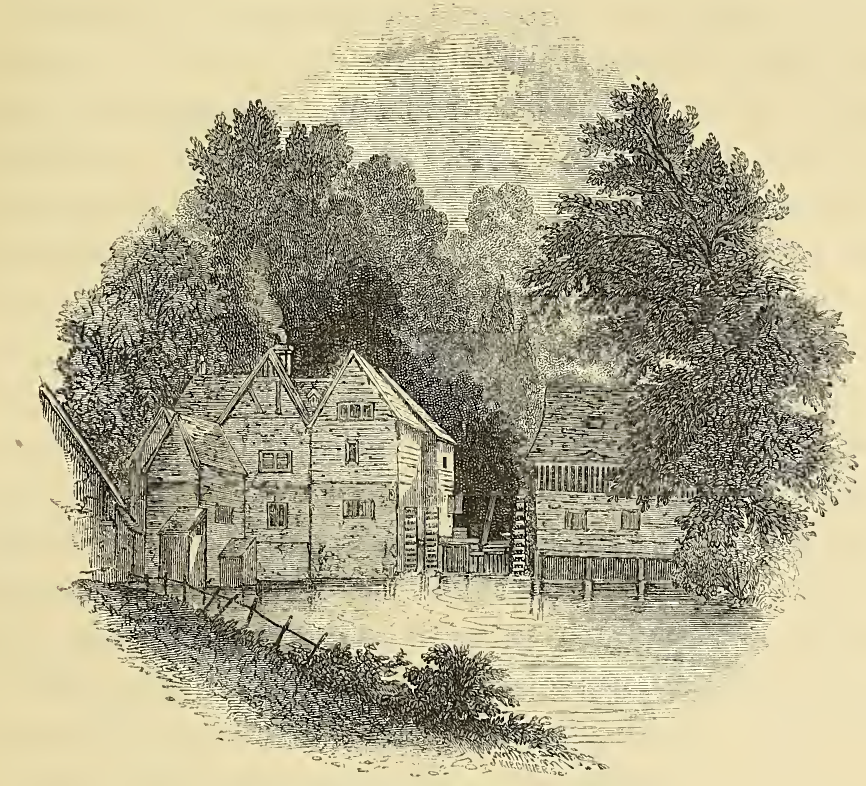

ESHING MILL FROM THE BRIDGE.

\section{CHAP'TER VII.}

The walks about Godalming are truly delicious, whether in winter or in summer, in spring or in autumn : one can never time one's peregrinations amiss as regards season. Eshing has ever been a favourite haunt with me; its old, old bridge, and its old, old mill, are bits for painters. There is a bank close by this bridge where I made my first acquaintance with the HEDGEHOG. My little dog; Cap - his name was once Capsicum, it afterwards shortened itself to Capsy, and finally settled in Cap-my little dog Cap, in the course of a journey of discovery on a keen, 
crisp, frosty day in January [Letter dated 17th January, 1835], poked his nose into a deserted rabbit-hole in this said bank at Eshing bridge. After a while, I heard from the bowels of the earth a yelping that plainly announced the discovery of some phenomenon in Natural History. The hole was very large, and the end was filled with leaves; after trying a good many contrivances that did not answer, I hit on one that did, and I hauled up a lump of dried leaves about as big as my head; outside, the leaves were loose, further in, close and tight, and after taking off layer upon layer, I felt some sharp instrument run into my hand, and I knew for certain that I had in my hand what $\mathbf{I}$ had often longed for, a somnolent hedgehog. I took him home, woke him up with a gentle warmth, and had the intense satisfaction of seeing him wander about a Brussels carpet, with his leafy great coat on his back, making him look for all the world like some new species of Armadillo. When he had satisfied my curiosity, I had a sackful of dry leaves shot down in a corner of the cellar, and in these I let piggy take out the rest of his nap, of which, as it afterwards appeared, a term of forty-one days was then unexpired.

Begging pardon of naturalists for such an accusation, I can't help saying that I think a great many fibs have been told about the hedgehog. In the first place the old wife's fables about sucking cows and so forth, were so horridly unbelievable, and yet so damaging to little hoggy's reputation with the vulgar, that the more erudite and more humane became his patrons and apologists, and made much more of him than he deserves.

Dear old White of Selborne must have been taking a nap when he told us about hoggy's liking for plantain- 
roots. "The manner," says White, "in which hedgehogs eat the roots of the plantain in my grass walks is very curious: with their upper mandible, which is much longer than their lower, they bore under the plant, and so eat the root off upwards, leaving the tuft of leaves untouched. In this respect they are very serviceable, as they destroy a very troublesome weed."* Boy and man this passage

* The idea that the hedgehog is phytophagous is rapidly losing ground; the following passages from the 'Zoologist' are applicable here :- "In the course of the autumn of 1841 , in one of my evening walks, I stumbled over a hedgehog, and on finding, by the sense of feeling - it was too dark to see - what it was, I took it up and conveyed it home. I kept it for several weeks, partly with a view to ascertain what it would or would not eat. The first kind of food I offered it was raw mutton, and when I offered the meat the animal had been in confinement about twenty-two hours; yet, notwithstanding it was in a perfectly strange scene, and had fasted only a part of the preceding night - at least I presumed so from the hour at which $I$ found it-it took the mutton into a corner of the room, and ate it greedily, making, at the same time, a singularly harsh sound in the process of eating. I placed apples, pears, potatoes, both cooked and uncooked, eggs, beef, mutton, mice, sparrows, \&c., in its place, and plenty of milk. Neither apple, pear, nor potato was ever touclied. The eggs were unmanageable by the poor captive, but when I gave them a slight crack, their contents were speedily abstracted. The mouse or sparrow was devoured at the first convenient opportunity, and at any hour of the day, while the beef and mutton always disappeared eventually. The fat was invariably left. So much for the food of the hedgehog. As to its habits I have little to say: I kept it all through the winter; its longest nap was for about two, at the most, three days. If I set it free in the room, or it made its escape from its box, it was very soon to be found among the ashes under the grate, attracted thither, I thought, by the warmth. If placed on a table, it never hesitated about running over the edge, rolling itself up in an instant (as noticed by Mr. Jesse, I think), and sustaining no harm from its fall. The gamekeeper tells me he catches many hedgehogs in his traps, which are invariably baited with flesh (Zool. 716), and generally that of the rabbit; and when defending the poor hedgehog one day, on the score of its harmlessness in respect of the game, he replied by saying he thought it very curious they should show such a strong penchant for rabbit meat, if really averse or indifferent to a game diet; and he feared that a tender young leveret in its seat would prove quite as tempting as half a young rabbit suspended over a trap. His reasoning was 


\section{tormented me many years, because I knew hoggy to be a blood-thirsty poacher, a regular knight-errant for attacking}

unanswerable: what could I reply? and as for the eggs of game, when he accused the hedgehog of that kind of poaching also, I could not say " $\mathrm{Oh}$ no, you are prejudiced there, you have never seen a hedgehog so engaged, and therefore you may be accusing him of other people's crimes ; indeed, I don't think he likes, or will eat eggs:" because I had had ample proof that if he spared an egg for three days, it was only because he was unable to get at its contents, and for no other reason whatever; and because $I$ have no doubt that a partridge's egg would be more manageable than a fowl's egg; and that if the hen partridge should by chance be near, and endeavour to defend her nest, she would be herself demolished by the plunderer, as easily as a ringdove or young turkey.-J. C. Atkinson; Hutton, Berwick-on-Tweed." Zool. 791.

"With regard to the hedgehog's guilt in devouring eggs of poultry or game, I can only state, that I have several times taken these animals in traps baited with a hen's egg, intended to ensnare carrion crows; but whether the hedgehogs had walked into the trap inadvertently, or whether they actually wished to obtain possession of the egg, I cannot say. The inference is certainly against them.-Archibald Jerdon ; Bonjedward." Zool. 856.

"That this animal is the subject of some 'vulgar errors,' may be perfectly true; but that it is carnivorous, I feel absolutely convinced. Many years ago I had opportunities of watching the animal, having captured and kept for a short time several individuals. They fed readily from the very first, and in particular some, to whom it was offered, drank milk from a saucer most greedily. The common garden shell-snails appeared very acceptable morsels, being cracked with the utmost ease (if not too large for the mouth), and champed down with the greatest gusto. Mr. Bury expresses a doubt (Zool. 818), whether the hedgehog will eat eggs; but I would suggest, that his experiment is not conclusive. He states having offered his urchin 'a bantam's egg ;' but I helieve those eggs havc not unfrequently very strong shells; certainly I have occasionally met with eggs, the shells of which would puzzle a larger animal than the hedgehog not having the $\pi \circ v \sigma \tau \omega$ for making the first fracture, nor the power of striking, as a bird, with its beak. If Mr. Bury would select a thin-shelled egg, or one with a cracked shell, perhaps the result would be different. To prove the carnivorous propensities of this aninnal, I may mention two circumstances, not indeed within my own knowledge, but of which I was informed, from an authority to be relied upon. In the first instance, a gamekeeper, having for some nights lost one of a brood of pheasants he was rearing under a hen, confined the latter to a corner of the coop, and set a rat-trap, whcrein next morning he found a hedgehog; thus convincing himself, as he 


\section{vipers, and a tyrant over all manner of mice and such small deer, and I thought it passing strange that he}

desired, what was the depredator. The other instance, of hedgehogs being: frequently caught in nets placed to intercept rabbits, though not so conclusive, certainly affords strong ground for suspicion. The bank, in which rabbits abounded, was close to a piece of water, and the nets were set between the burrows in the bank and the uplands, so that the only apparent temptation to the hedgehogs was either the water, or the young rabbits. - A. Hussey; Rottingdean." Zool. 857.

"A few summers ago I placed a hedgehog in our garden, which, being walled round, I was certain he could not escape from; believing, then, in his innocence, and fancying to myself the good he might do in the way of regaling himself upon beetles, and other vermin. It chanced, however, that a brood of young ducks, with their foster-mother, a hen, the latter under a coop, were also placed there. Not many days elapsed before two or three ducklings were missing; who the thief could be was a mystery, still the ducks disappeared, one by one, or were found dead and mutilated. A cat was suggested as the aggressor. No. A rat! No, not likely. It could not be the hedgehog? Oh! certainly not. However, the remains of a dead one being left one morning a short distance from the coop, I fastened it in the evening to a trap, removing the remaining live ones away, hoping thus to solve the riddle, and the following morning there was my harmless hedgehog, caught in the very act of making a grip at the poor little duck. The survivors were again placed in their former situation, and remained unmolested, thus bringing home the guilt to Mr. Hedgehog pretty conclusively. - Christopher Parsons; North Shoebury Hall, near Rochford, Essex." Zool. 857.

"A relation of mine, along with some other boys, at the 'Blaeberry time,' this summer, alighted upon a pheasant's nest. Returning to the place a day or two afterwards, curiosity prompted them to examine, and see how the eggs fared. They were much surprised at finding a stranger inmate in occupation. This was a hedgehog, which they had interrupted in the enjoyment of his ambrosia. One taken into the house, ate apples, and supped porridge and milk (for it was in Scotland), and when not otherwise engaged, delighted to roll himself up in the coziest nook of the fire-place, which, as it was in summer, was filled with shavings.-James Hardy ; Gateshead." Zool. 85\%.

"I have until within the last year or two been a strenuous defender of the hedgehog from the charge of destroying game, which has been brought against it. The facts mentioned in the 'Zoologist' (Zool. 715), in the interesting paper 'A Last Word for the poor Hedgehog,' together with the assertions of several gamekeepers, with whom I have conversed on the subject, induced me 


\section{should take to cooling his copper with the roots of the old gentleman's plantains. However, the tastes of pigs and}

to alter my opinion as to its entire harmlessness; but the following fact, which came under my own observation last week, so fully convicts the animal in question of the charge of carnivorous habits, as to remove me from the list of his defenders. While walking one evening, I overtook a large hedgehog, which appeared just to have set out on its nocturnal rambles. I carried him home, and gave him the run of a small walled garden. In the middle of the second night of his captivity, I was awakened by the loud and alarmed cackling of a couple of fowls, the fattening tenants of a coop in the same garden. On looking out of my bed-room window, expecting to see some biped midnight plunderer, I could discover nothing but the dim outline of the coop. Upon listening, however, I heard the cries of the chickens repeated, but now with the addition of a perfectly distinct sound, for literally 'thrice; and once the hedgepig whined,' and I was no longer at a loss to guess the cause of the alarm of the fowls. I immediately lighted a candle, dressed, and went out to inquire more particularly into the affair, expecting to find the urchin at the bars, scaring the imprisoned fowls. I found, however, that he lad crept through a space not quite three inches in width, into the coop, and that he was engaged in close combat with one of the fowls, whose life's blood he would have drank, had not my timely arrival prevented the tragedy! From that moment the last remaining spark of my love and respect to his race as an inoffensive and much maligned one, was quenched. Until then I cherished the hope expressed by your correspondent, W. H. S., and by Mr. Waterton, in his very interesting 'Essays,' that the carnivorous habits of the hedgehog were the effects of confinement, and a lack of their natural food, and did not arise from any innate propensity in them to prey upon these animals. But the case $I$ have mentioned, destroys, I think, even this charitable hope. Here was the very experiment which W. H. S. suggested as one which ought to be adopted, in order ' to try the matter quite fairly.' A hedgehog is placed in a walled garden, which is known to contain beetles and other insects, he is also supplied with milk, yet on the very next night, instead of quietly feeding on his supposed natural food, he is discovered in the act of killing a full-grown fowl, having insinuated himself through the narrow bars of its coop for that purpose! This is a case so strong (and having seen it myself, I can vouch for its accuracy), that unless carnivorous propensities are natural to the hedgehog, it is impossible to ascribe it to any other cause than $\mathrm{Mr}$. Waterton's suggestion, that they were at the time ' not quite right in their head.' If it was so with my hedgehog, I can truly say there was method in his madness!-John Pemberton Bartlett; Kingston Rectory." Zool. 1204. 
men are every now and then somewhat eccentric, so I left the matter sub judice, until chance solved the mystery. In a grass walk I saw some flattened plants of the common plantain withering and half dead; by the side of each I found the hole, bored, as White supposed, by the long upper mandible of the hoggy, but it was scarcely big enough to admit a lead pencil, and so round and smooth that I said directly to myself, 'tis the burrow of a nighteating caterpillar : I got a trowel, and in a trice the fellow was unearthed, and he afterwards turned to a ghost-moth* or yellow underwing, $\dagger$ I can't say which, for both came out in one cage.

The hedgehog is properly a nocturnal carnivorous animal; he prowls about at night, like an owl, looking after the nests of pheasants, partridges, corncrakes and larks : he kills the old ones if he can, and sucks their eggs if he can't : now and then he overruns a rabbit; but his favourite dish is a snake or an adder; he catches these while dozing under cover, and suffering from repletion caused by four or five mice lying undigested in their stomachs, tail on; and it is then that desperate fights ensue: it is then that his armour stands hoggy in good stead: the deadly

"Some years ago I had three or four hedgehogs, which I kept in a garden, of which they had the range; in the same garden $I$ also had several rabbits: after they had been together for some days, I found that a rabbit was killed every night, the remains of the skin and bones only being left : this $I$ supposed to be done by my neighbours' cats, and prepared to wage war on them accordingly, but to my surprise, on peeping into the garden early one morning, I saw a hedgehog busy at work with his nose buried in the fresh-cut throat of an expiring rabbit; and from further observations, I had no doubt that the hedgehogs had been guilty of all the murders. - R. Davis, jun.; Clonmel." Zool. 1293.

* Hepialus Humuli.-E. $N . \quad+$ Triphæna pronuba.-E. $N$. 
adder, infuriated at feeling hoggy's teeth griping her back, lashes her head against a skin less vulnerable than that once said to have been worn by a Mr. Achilless. The pluck and power of both is tried to the utmost, but hoggy is almost sure to triumph in the end, and the adder, half devoured, is often found next morning by the countryman, who wonders "how he come so mauled." I take it that the spiny coat of the hedgehog is Nature's defence against the poison fangs of his favourite prey.

Yesterday was St. Valentine's day.* I had the good luck to meet with a companion as idle as myself, and as fond of the smell of the fresh air; and, without horse, dog, or gun, we wandered up the sandy lane leading to Eshing. Near the top of the lane we observed a whole family of the LONG-TAILED TIT threading the branches of an elm tree, in search of insects. The little fellows are all fluff and feather; they seem to have no body at all, but to consist of a lump of down, nearly round, with one long feather stuck in the middle of it for a tail: their cry is weak, peevish, and often repeated, and when frightened away from one tree they go off to another in regular order, all in a line, jerking up and down, and holding out their long tails in a straight line behind them: in this party were fifteen, no doubt the hatch of a single pair last year.

On the old bridge at Eshing we were delighted to see a whole colony of that lovely little flower, Draba verna. Although it was the first time I had seen this beautiful forerunner of spring, it seemed, from the quantity in flower, to have been blooming for two or three weeks. I brought home several plants of it; one is now before me, growing

* Dated 15th February, 1835.-E. N. 
and flourishing with plenty of earth on a sixpence : it has nineteen leaves, and five full-blown flowers, yet no part of it extends to the circumference of the sixpence. Is not this the smallest flowering plant known? It has long been a favourite of mine, and year after year the first plant I find of it is brought home, and commonly killed with kindness.

On the river bank we saw a DABchick. Why it should have got ashore I cannot tell; I never saw one out of water before. When I observed it first, it was standing: bolt upright; but, the moment it spied us, it dropped down on its breast, and tumbled head over heels into the river.

As we wound our way up a steep field by Milden's Wood, I was within a tittle of stepping on the back of a HARE. She had scratched out just enough of the sandy soil to bring her back level with the surface; one fore foot was stuck straight out before her, and on this rested her head; her ears fell on her neck on each side, and touched the ground: her eyes, large, bright, and black, were fixed intently on me; and the instant that my own eye caught hers, I saw a slight movement; the nose had slid off her foot to the ground, and the other foot had been stretched out: this movement had lowered her head, 'which was now but a fraction above the level of the hill-side; and so exactly was she the colour of the surrounding soil, that, but for the lustrous eye, I could not have persuaded myself there was a living creature there. I pointed her out to my friend, who, in his eagerness, had as nearly stepped on her as I had. There we stood, about two yards apart, and puss motionless as a stone between us. "I'll trouble you to move, madam," said I, at the same time applying my 
toe very gently a posteriori: puss took no notice; and my friend pounced on her, seized her, and held her up by the ears singing out the "who-oop" at the top of his voice, she kicking with all her might, and crying the same plaintive and piteous "aunt, aunt, aunt," which has often moved my compassion for these harmless creatures when the hounds have once taken their fatal hold of them. However, I sued for her liberty, and he put her down : away she went, scampering up the hill like a mad thing. Hares never run down hill if they can help it; and if there is no possibility of running up, they take the hill-side at a slant. When at the top, we turned round to gaze on that lovely valley; yes! lovely, even in the bleak dreariness of February. The clumps of gloomy pines, the never-ending twinings and twistings of the silvery $W$ ey, and the thousand hills, small but beautiful, peeping one over the other till overtopped by the blue undulating outline of Hindhead, all tend to make this a view, to me at least, of unceasing interest. Talking of the affairs of the nation, we reached Northbrook.

While seated on a stile there a very large rat came bustling down the hedge just before us, bringing with him a lot of loose earth : my friend was just jumping down for a stone to whirl at him, when a little bit of a WEASEL followed the rat down the bank, holding his head well up, like a fox-hound running breast-high. The rat had crossed the path, and got into a little, low bank on the other side of the foot-path, over which he scrambled, and came out among some swede turnips in the adjoining field, at the very moment the weasel went into the low bank hunting him. The turnips were so small, and so far apart, that we did not once lose sight of the rat. He ran in and out 
among them, continually crossing his own track, and then, making a little circle, he came to the bank a good way from where we sat, and, climbing over it, got into the footpath about a hundred yards from us; he then ran towards us with all his might, straight along the middle of the path, and passed under the stile on which we were perched, motionless and smiling, like the statues of Tam o'Shanter and Souter Johnny, and about ten yards behind us he went into the thick bank, and was lost to our view. The weasel hunted well in the little, low bank, and seemed a good deal puzzled, staying there much longer than the rat; at last he seemed to find out that the game had taken to the turnips : here he pursued him with great earnestness; but, finding the trick that had been played to puzzle him, he made a cast, like a well-trained fox-hound, going completely outside all the trail : by this scheme he gained on the rat by hitting off the scent just where he had gone over the little bank the last time. In a few moments he was in the foot-path, and came galloping towards us in fine style, his back arched, his head up, and his tail in a straight line behind him.* He passed under us, and in his

* It appears from the following extract that weasels occasionally pursue their prey in packs:- " The following remarkable anecdote was communicated to me by Mr. W. Withington, Curator to the Fairfield Mechanics' Institute. A gamekeeper in the employ of Mr. Hume, of Medlock Vale, whilst taking an early stroll in the woods that border on the river, saw a hare pass near him, apparently much fatigued with long running. He stood on the watch, expecting to find some poacher's dog in pursuit, and soon heard a faint cry or yelping, which could not proceed from dogs. A large pack of weasels then came in view, in full cry after the hare, which they must soon have overtaken, as it was already exhausted. The chase was, however, stopped by the gamekeeper discharging both barrels into the midst of the weasels, when, according to his own probably heightened account, seventeen remained dead, and the rest dispersed. I might add, that weasels are exceedingly plentiful along the Medlock.-J. W. Slater; Fairfield." Zool. 1462. 
eagerness overshot the spot where the rat had gone into the bank : it was only for a moment, he came back, quartered the ground, found the trail, and was in the bank in no time. A blackthorn overhung the path; we saw something move in it; it was the rat; the weasel was going up the stem; he was close after him; he evidently viewed him ; he gained on him; the rat dropped himself into the foot-path, the weasel did the same, and followed him up the bank within a foot: we heard a shrill cry, first long, then short, shorter, then all was still; we went quietly to the place; the weasel left his prey, hissing at us like an angry cat; the brain of the rat was laid completely bare, but his little heart continued beating for nearly a minute as I held him in my hand.

A Thrush was shouting out his sonorous vespers or the requiem of the rat from the topmost twig of an old elm tree, black, drear, leafless, budless, and offering no token of the spring which the sweet bird on its summit seemed so blithely to herald; but it was St. Valentine's day, and he was inspired by love.

When I got home I sat down and made these notes for you, and as they do not fill my paper, I will add one or two mems about the weasel, which have for a long time been standing by to be let go. The weasel is a very awkward-looking animal when running on level ground; his great length and slenderness of body, and the shortness of his legs, are very much against speed ; but in climbing trees, or threading the long and narrow galleries of fieldmice, this seeming disproportion is of the greatest use to him. I have seen him coursing along the boughs of a tree, winding himself round, above or below, just as suited his purpose, with all the ease and agility of a squirrel. I 
have watched him enter a wheat-rick at the bottom, and in less than a minute seen him peeping out under the thatch : but in mentioning this I am on dangerous ground; I fear I shall neither make you nor your readers believe that wheat-ricks are very often a complete honeycomb, with the galleries made in them by mice and rats, extending from the very crown to the faggots on which they are built; and that hundreds of these vermin are frequently found in one rick. However, where there are many rats there are few mice, and where there are many mice there are few rats; because the rats, being strongest, expel the mice. To return to the weasel : his usual habitation is the gallery of a field-mouse on whom he has served a writ of ejectment, and he usually chooses one in a bank in which the roots of bushes are tolerably plentiful and strong, as he well knows that these will effectually prevent his being dug out by any evil-disposed person or persons : he also invariably takes the precaution to select a burrow with two openings, so that, if one is besieged, he makes his exit at the other. I very well recollect seeing a weasel go into a little round hole, scarcely bigger than the hole of a wasp's nest; I immediately put my foot on it, and despatched a lad who was with me for a spade, determined to take the little fellow alive. The spade came, we dug away, cut through roots, pulled down the bank, and did no end of mischief; and, after two hours' labour, found that the hole went right through the bank, and came out on the other side.

The weasel has an excellent nose, as. I think $\mathbb{I}$ have pretty clearly shown above; but it is not exercised on the trail of rats only. I have, on two occasions, seen rabbits pursued by him, run down, and killed: one was on Munsted 
Heath, the other on Highdown Ball. In both instances, the rabbit seemed stupefied or fascinated by fright; in one instance running round and round, and not taking the right precaution for escape ; in the other, starting, stopping, and, as I fancied, trembling with fear. When its prey is taken, the weasel rarely eats more than the brain.

The thermometer has sunk $27^{0}$ since this time last month, when $I$ began this epistle, and the snow has nearly blinded me to-day in a gallop along the Hog's Back:* but never mind ; "a cold March, and a crop of wheat," is an old and a very true proverb; we shall have a cheap loaf. The crocuses have remained for three weeks precisely in statu quo, and the hedgerows are still as black as on St. Valentine's day, except where a warm nook has allowed them sun, and has protected them from the keen wind. In such situations the whitethorn is beginning to be gemmed with green, and the palm willow displays its velvety catkins looking as though they would gladly return to the winter coverings which they have lost. Up Godbold's the giant aspens have put forth their catkins in unusual quantities, so that the ground below is strewed with those which the fierce wind has carried away from their moorings on the twigs; none of them have shed their pollen, and, as they lie on the ground, they look more like great, red caterpillars than anything vegetable. The female blossoms of the hazel, which a month back, under the influence of a mild south-wester, were fresh and clear, and bright red as the happy and innocent lips of a young, laughing beauty, have turned dark and withery, as that beauty may hereafter turn under the destroying influ-

* Dated 13th March, 1835.-E. N. 
ence of the bitter blast, unrequited love. Even now the wind is whistling under the door of my little room, in spite of a leather binding, and heaving up my carpet into the most unseemly convexities; while the feathery snow is driving in horizontal lines past my window; yet at this moment I hear the loud, monotonous song of the misselthrush, bravely defying wind and weather.

Our vines are often annoyed, and sometimes rendered barren, by an insect which is called the vine-gall, or VINECoccus. The harm it does the vines is by pricking holes in the rind, and thereby letting out the sap, or, as the gardeners scientifically term it, making the vines bleed. Our climate is not hot enough for this insect to breed very fast out of doors ; but in hothouses it thrives and swarms, often doing great mischief. Sometimes there are such hosts of them, that the young shoots are covered with a white cotton, which is in reality a resinous gum, produced by the Cocci. The Coccus pierces the bark by means of a sharp and long sucker, which goes to the very centre of the shoot, causing the sap instantly to flow in abundance. This piercing apparatus, although, like other insects' mouths, in the head, is bent so far under the breast, that it appears to proceed from that part, and I find has been often so described. The Cocci in the young, or larva state, are all alike; they look just exactly like little tiny tortoises fixed to the rind and sometimes the leaves, of the vine. Like other animals, the Cocci are males and females; the males are desperate rovers. When they are tired of regetating, they push a hole through the back of their tortoise-like shell and fly away; the females undergo no change in form on coming of age, nor do they ever break loose from their moorings. 
The male and female Coccus are very different not only in size, but in make: the male is a small, active, twowinged fly; the female is a large, lazy, and almost lifeless lump, ten times the size of the male, and so closely attached to the rind of the young shoots on which she feeds, that you cannot get her away without killing her. When the female has attained this immense size, and her whole body is full of eggs, she begins laying them, her body being glued down all round at the edges to the rind of the twig; but between her body and the rind, except just round the edges, is a quantity of cottony gum, spread over the whole space which she covers. The laying of eggs is on a different system to that of any other insect : the first egg is laid in the cottony substance without causing any disturbance to the margin of her body glued to the rind; it does not stick, like most other insects' eggs, but lies quite loose in the cotton; then another is laid, which pushes the first a little forwards; and then another, and another, none of them being visible from without; so that all the eggs that the female Coccus lays she sits on, for all the world like a broody old hen.

The female Coccus, like a good many other insects, when come of age, is a complete bag of eggs. Now you will observe, that as she lays them, and then pushes them under her body, they must raise up the under skin of her body into a manifest concavity; so that the body itself daily gets thinner and thinner, while the pile of eggs which it covers gets thicker and thicker. At last her stock of eggs is exhausted; the under skin of the body meets the upper skin, and grows hard and fast against it; then the old lady dies, and her body, like the roof of a house, protects the inhabitants below from the inclemency of the weather. 
In a few days from the death of the mother, the eggs hatch, and become lively little runners, of a bright red colour. These first devour the cottony stuff among which they were born ; then they manage to lift up the edge of their covering, and away they run, helter-skelter. This active life lasts but a short time : they soon get hungry, pierce the rind of the twigs, anchor themselves by the beak, settle down to serious eating, and become fixtures for life.

Did you ever observe the FuIES on the sunflowers cleaning themselves? They first have a good long feast of honey, and cover themselves with pollen; eyes, legs and wings, all as yellow as gold. When one of the thieves has managed to get so polleny that he can't see, he sets to work to clean himself : it is most amusing to see his operations; the hind legs clean the wings, and the fore legs the head; with great skill the pollen is scraped off the head, eyes, and face, and then rolled up into pellets by the fore legs and thrown away with a kind of jerk. I have seen this done fifty times. The Humble-Bees on a sunflower are also very odd-mannered; they get as drunk as Bacchus or Silenus; then they get sleepy as Morpheus, and cross as Cerberus; if you touch one he leans on one side, cocking up the opposite legs into the air, and plays divers other antics, till, with his various trials to show that he is compos mentis, and able to fight and defend himself, he sidles, staggers, rolls, and falls to the ground, and there lies on his back till he has slept himself sober.

Ever since I first wore that garment, which in this privileged country is supposed to imply that the wearer thereof is, or is to be, one of the lords of the creation, the house and premises situate to the west of Godalming, and extending from the town to the Gill property at Eshing, 
have been known by the name of Godbold's : before that great era in the affairs of men, when it pleased my mother to clothe me in the noble garb before alluded to, it was denominated Oglethorpe's. On these subjects, bursting, as they seem to be, with all those factella, or little facts, which make a story pleasant, I must be silent for the present; the only object I now have in mentioning Godbold's, is to say that it was there I watched the manœuvres of the Burying-Beetle. Waring Kidd had shot a bulfinch, but it was spoiled for stuffing, and thrown down as useless by the side of the path just by the bath. It was on this bulfinch, and in this situation, that I had the pleasure of seeing the burying-beetle at work.

Two days after, I was again in Godbold's ; and seeing the bulfinch lie where he had been left, I lifted him up by a leg, intending to make a present of him to a fine colony of ants established a little further on in the days of General Oglethorpe, and which had maintained their station ever since. They had made many a pretty skeleton for me, and I intended to add that of a bulfinch to the store, but the buzz of a beetle round my head caught my ear; he flew smack against the bulfinch which I was holding up by the leg, and fell at my feet. I knew that the gentleman was a burying-beetle, and as I put the bird down for him, he soon found it, mounted upon it, and, after much examination, opened out his wing-cases, and flew away. I will profit by his absence, to tell you a bit of his history.

The burying-beetle is about an inch in length; he is black, with two bands across his back of a bright orange colour; these bands are formed by two blotches of that colour on each of the wing-cases : he is a disgusting crea- 
ture, though in such a gay dress, being so fœtid that one's hands smell for hours after handling him; and if he crawls on one's coat, or other garments not often washed, the smell continues for days. The whole tribe of buryingbeetles lay their eggs in the bodies of dead animals, which, when possible, they bury for the purpose. In Russia, where death itself does not do away with distinctions, the poor people are buried but a few inches under ground, the coffin consisting of four boards roughly nailed together, and not particularly well fitted; the operation of burying is often at the expense of the country, and therefore done from necessity, not love. This mode affords great satisfaction to the burying-beetles, as it saves them the labours of the gravedigger. They avail themselves of the bodies placed so nicely within their reach, and the graves are pierced with their holes in every direction; at evening, hundreds of these beetles may be seen in the Russian buryingplaces, either buzzing about the graves, or sitting placidly at the mouths of their burrows, which lead into them.

The burying-beetle in this country seldom finds so convenient a provision for him, and he is under the necessity of taking much more trouble ; he sometimes avails himself of dead dogs and horses, but these are too great rarities to be his constant resort: the usual objects of his search are dead mice, rats, birds, frogs, and moles ; of these, a bird is most commonly obtained. In the neighbourhood of towns, every kind of garbage that is thrown out attracts these beetles as soon as it begins to smell; and it is not unusual to see them settling in our streets, enticed by the grateful odour of such substances.

The burying-beetles hunt in couples, male and female; and when six or eight are found in a large animal, they 
are almost sure to be males and females, in equal numbers: they hunt by scent only, the chase being mostly performed when no other sense would be very available, viz., in the night. When they have found a bird, great comfort is expressed by the male, who wheels round and round above it, like an eagle, - the female settles on it at once, without this testimonial of satisfaction; the male at last settles also, and the bird undergoes the scrutiny of four, at least, of the senses,_-touch, smell, sight, and taste, - for their heads are continually diving among the feathers of the bird, and a savoury and ample meal is made before the great work is begun. After the beetles have appeased the calls of hunger, the bird is abandoned for a while; they both leave it to explore the earth in the neighbourhood, and ascertain whether the place is suitable for interment : if on a ploughed field, there is no difficulty; but if on grass, or among stones, much labour is required to draw the body to a more suitable place. The operation of burying is performed almost entirely by the male beetle, the female mostly hiding herself in the body of the bird about to be buried, or sitting quietly upon it, and allowing herself to be buried with it: the male begins by digging a furrow all round the bird, at the distance of about half an inch, turning the earth outside ; his head is the only tool used in this operation ; it is held sloping outwards, and is exceedingly powerful. After the first furrow is completed, another is made within it, and the earth is thrown into the first furrow : then a third furrow is made, which, being under the bird, the beetle is out of sight: now the operation can only be traced by the heaving of the earth, which soon forms a little rampart round the bird; as the earth is moved from beneath, and the surrounding rampart in- 
creases in height, the bird sinks. After incessant labour for about three hours, the beetle emerges, crawls upon the bird, and takes a survey of his work. If the female is on the bird, she is driven away by the male, who does not choose to be intruded on during the important business. The male beetle then remains for about an hour perfectly still, does not stir hand or foot; he then dismounts, diving again into the grave, and pulls the bird down by the fear thers, for half an hour : its own weight appears to sink it but very little. The earth then begins heaving and rising all round, as though under the influence of a little earthquake : the feathers of the bird are again pulled, and again the bird descends. At last, after two or three hours' more labour, the beetle comes up, again gets on the bird, and again takes a survey, and then drops down, as though dead, or fallen suddenly fast asleep. When sufficiently rested, he rouses himself, treads the bird firmly into its grave, pulls it by the feathers this way and that way, and, having settled it to his mind, begins to shovel in the earth: this is done in a very short time, by means of his broad head. He goes behind the rampart of earth, and pushes it into the grave with amazing strength and dexterity; the head being bent directly downward at first, and then the nose elevated with a kind of jerk, wlich sends the earth forwards. After the grave is thus filled up, the earth is trodden in, and undergoes another keen scrutiny all round, the bird being completely hidden; the beetle then makes a hole in the still loose earth, and having buried the bird and his own bride, next buries himself. The female lays her eggs in the carcass of the bird, in number proportioned to its size; and after this operation is over, and the pair have eaten as much of the savoury viand as 
they please, they make their way out, and fly away in quest of further adventures. The eggs are hatched in two days, and produce flat, scaly grubs, which run about with great activity; these grubs grow excessively fast, and very soon consume all that their parents had left. As soon as they are full grown, they cease eating, and burrowing further in the earth, become pupæ. The length of time they remain in this state appears uncertain; but when arrived at the perfect state, they make round holes in the ground, from which they come forth.

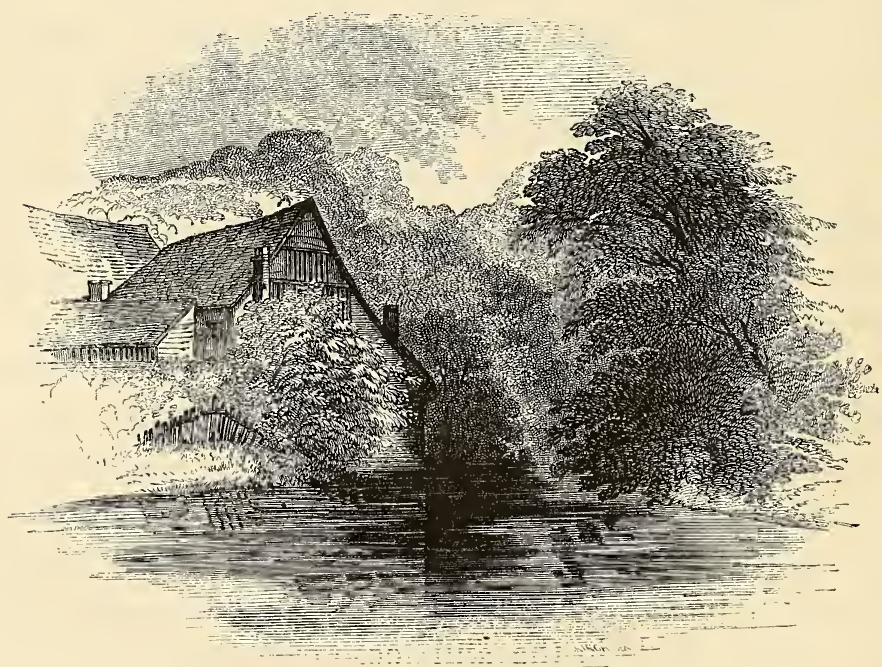

LEATHER MILL ON THE WEY AT THE BACK OF GODBOLD'S. 


\section{APPENDIX A.}

An Outline of the Flora of the Neighbourhood of Godalming, in the County of Surrey; with brief Notices of the Geological Features of the District. By J. D. Salmon, Esq.

In bringing the Flora of Godalming and its neighbourhood before the notice of botanists, it is necessary that the limits of the district should be clearly defined, and that the geological features which present themselves should be noticed: for the outline of the latter I have availed myself principally of Dr. Mantell's Memoir in Brayley's 'History of Surrey.'

Extent and Boundary. - The tract of country about to be illustrated is comprised within a square, the sides of which are about eight miles in extent, having Godalming for the centre; every portion of the district is therefore within a moderate walk of the town.

The chalk ridge, well known as the Hog's Back, running east and west, has been taken in part as the northern boundary; a narrow slip of London clay on the north side of this range, is, however, included within the district, as affording an additional variety of soil. From the abrupt termination of the Hog's Back at Guildford, the northern boundary is continued along to Merrow Downs: from thence the eastern boundary passes by St. Martha's Chapel, and crossing the valley of Chilworth by the powder-mills, it skirts Blackheath to Shamley Green, is continued across the Wey and Arun canal to the junction of the 
Cranley and Horsham turnpike-roads, and follows the latter to Pain's Hill.

The southern boundary is taken hence in a westerly direction through the wealden clay, immediately at the base of the lofty range of hills commencing at Hascomb Beech, ard terminating at Bowler Green, near Hindhead. From this point the western boundary is formed by an imaginary line through Cosford crossing Thursley Common to Elstead, and continued thence over Crooksbury and Puttenham Commons by Hampton Lodge, passing over the Hog's Back near Shoeland Farm to the commencement of the northern boundary.

Geological Features of the District. - In noticing these, I commence with the northern limit, which is a termination of the London clay resting upon the chalk. I am not aware that any portion of the plastic clay is to be found within the limits : the Bagshot sand, which is so conspicuous, does not approach nearer than Romping Downs, about two miles distant. The principal feature is the beautiful chalk ridge called the Hog's Back, which scarcely exceeds half a mile in breadth. "This remarkable ridge of the North Downs extends from Guildford to a point about two miles from Farnham, and has evidently been produced by an upthrow of the chalk, and the breaking off of the southern portion of the curve. The inclined position of the remaining side of the flexure is seen at the western extremity of a large chalk-pit, between Guildford and Puttenham, where the strata dip towards the north at an angle of about $30^{\circ}$. The upper beds are very white, with courses of the usual dark flint nodules; and a remarkable feature in this quarry is the distinctness with which the chalk is divided into masses approaching to a rhomboidal figure, by seams oblique to the stratification; the angles of the portion thus formed standing out in the face of the cliff, like splinters in the shattered fracture of a crystal."

Descending its southern side we meet with a narrow stratum of fire-stone, which "forms a slight projection along the foot of the Hog's Back; the galt, a corresponding depression along its whole length," varying in breadth from a few hundred yards 
to a quarter of a mile, towards the eastward, opposite Littleton. Having passed this tract, we approach the principal stratum of the district, which is a portion of "one of the most extensive surfaces of the Shanklin sand in England. This sand rises rapidly in many places to a considerable elevation: at St. Martha's Chapel it equals or out-tops the chalk, though less than a mile from it horizontally." This character extends over a great portion of the district, presenting numerous acclivities, the most conspicuous of which are St. Martha's Chapel, already mentioned, Chinthurst Hill, heights around Godalming, Highdown Heath, Hascomb Beech, and the ridge of hills stretching thence by Burgate, Hambledon, Wormley and Barnacle Hill towards Hindhead, where an elevation of upwards of 900 feet above the level of the sea is attained.

The heights in the immediate vicinity of Godalming offer excellent sections of the Shanklin sand. Holloway Hill affords a good example of the strata, which are composed of loose sandy materials, and abound in large concretions of chert and of Bargate-stone, "a conglomerate of quartz-grains and pebbles, held together by a strong calcareous cement, which is hard and sparry, and much used for the purpose of building."

"The ferruginous concretions termed carstone are abundant on the Witley and Thursley Commons, and from being so compact as to ring under the hammer, are called clinkers by the quarrymen. This stone sometimes occurs in plates or flakes, more than a quarter of an inch in thickness, and curved so as to resemble portions of consecutive layers of petrified wood." It furnishes an excellent road-material; and gives that remarkable reddish hue to those roads which are Macadamized with this stone. Fragments of brown hæmatite, a kind of iron ore, occur in this district. There were anciently several iron-furnaces, of which the only memorials are four large ponds, called the Hammer Ponds.

The only remaining portion of the district to be noticed is that forming the southern boundary, and which is occupied by the clay formation of the northern limit of the thickly wooded weald of Surrey. 
The General Aspect of the District.-In many parts it is highly diversified with hill and vale. The town of Godalming stands on the high road to Portsmouth, and is pleasantly situated in a beautiful valley bordered by steep hills, the sides of which, for the most part, are richly clothed with ample foliage, rendering the surrounding scenery highly picturesque. This character extends more or less through the adjoining valleys towards Guildford, adding much beauty to the general scenery; and from the different eminences a series of splendid views is to be obtained. The Hog's Back commands a most extensive prospect. The view towards the southward presents a magnificent landscape; in the foreground, the undulating ridges of the various hills, interspersed with beautiful winding valleys, presenting to the vision a lovely and rural scene. Further on, the eye wanders over the whole extent of the weald of Sussex, rich in foliage, and only arrested to the eastward by the bold and mountainous ridge of Leith Hill, which rises to an elevation of nearly 1,000 feet above the level of the sea. This splendid panorama is backed by the lofty outline of the South Downs, which border the English Channel and extend into Hampshire. "The most fervent pencil of picturesque enthusiasm would fail to depict in apposite colours the glorious prospects from St. Martha's Hill; on every side, a rich and almost unbounded view presents itself, intermingled with every charm which landscape scenery, in all its diversity of character, can exhibit. Towards the south the prospect extends across the weald of Surrey and Sussex to the South Downs and the sea; and on the north, the eye ranges over a portion of the valley of the Thames as far as the high chalk range of Oxfordshire near Nettlebed, from which the summit and chapel of St. Martha's are distinctly seen."- 'History of Surrey,' v. 134. From other points the views are equally extensive, penetrating into the adjoining counties.

The extensive heaths, "though not unpicturesque, are wild and barren in their aspect, destitute of wood ;" yet there are several large ponds, formed by the embankments across the valleys, the margins of which will afford much pleasure and gratification to the ardent botanist. "The surface is, in fact, to this hour, 
nearly such as it may be conceived to have been when first uncovered by the departure of the sea." The whole district is intersected with delightful valleys, through which run several rivulets, that flow into the Wey from various sources, amongst which is one that is rendered classical by the delightful author of Selborne. This, meeting the Blackdown stream at Headley, is joined by the Alton and Farnham branch, at Tilford-bridge, where they form a considerable stream. From this point the Wey proceeds in an eastwardly direction by Elstead \&c., receiving in its course several small streams from the neighbourhood of Thursley and Witley, one of which takes its rise in the Devil's Punchbowl, from which source flows a delicious stream, as clear as crystal. The river, after passing by Godalming, from whence it is navigable by the addition of a canal, runs through a long line of pleasant meadows to Guildford, and in its progress receives the tribute of two additional streams, the Arun canal and the Tillingbourne, which add much to its importance; it ultimately falls into the Thames near Weybridge. According to Mr. Stevenson, "the waters of the Wey are of much less fertilizing quality than other streams in Surrey. This is attributed to the sandy country through which the Wey flows in the beginning of its course, and to the large quantities of sand which, after every heavy shower, are washed into the river from the steep hills near Godalming."

Localities of Plants. - From the diversity of soil included in the foregoing sketch, it is evident that many of our rarer plants may be expected to be met with. The Flora of the district will be better elucidated under the three following divisions.

The first division comprises the chalk and adjoining strata of London clay and galt, forming a large portion of the northern boundary. This district is rich in Orchidaceæ and other calcareous plants. The extensive quarries at Compton and Wanborough will afford a rich treat to the admirer of this beautiful and interesting tribe of plants. Orchis pyramidalis, Gymnadenia conopsea, Listera ovata, Aceras anthropophora, and Herminium 
Monorchis may be found in this locality in the greatest profusion; Ophrys apifera and $O$. muscifera more sparingly.

The following interesting plants are found in this part of the district. On the face of the quarries, Arabis hirsuta; on the sloping débris, Reseda lutea, Viola hirta, Rhamnus catharticus, Anthyllis Vulneraria, Hippocrepis comosa, Onobrychis sativa, Poterium Sanguisorba, Asperula cynanchica, Phyteuma orbiculare, Thesium linophyllum and Juniperus communis, in abundance. Gentiana Amarella equally so upon the level surface, as is the case with Carduus acaulis and Carlina vulgaris; in the same situation Chlora perfoliata is occasionally met with. On the ridge, Taxus baccata is abundant, many of the trees denoting a good old age. Cineraria campestris has been found on a down towards the New Inn. Lathræa squamaria, Inwood copse, on the north side of the Hog's Back.* Monotropa Hypopitys in some seasons is plentiful under the beech trees in a plantation overhanging the Compton quarry; in other seasons scarcely a plant is to be seen. Upon the lands forming the sloping portions of the Hog's Back, the following plants are generally distributed: Pastinaca sativa, Torilis nodosa, Tragopogon pratensis, Picris hieracioides, Specularia hybrida, Linaria spuria, L. Elatine and L. minor, Calamintha Acinos, Galeopsis Ladanum and Euphorbia exigua. Pyrus Aria cannot fail to attract attention by the snowwhite under surface of the leaves, which are rendered very conspicuous by the slightest breeze of wind. Clematis Vitalba trails over all the fences, in which also Viburnum Lantana and Ligustrum vulgare form a prominent feature upon divers portions of the chalk ridge. Several interesting plants are to be met with in an old discontinued chalk-quarry at the back of Losely Park. In addition to the several species of Orchidaceæ before enumerated, Scabiosa Columbaria, Helminthia echioides and Campanula glomerata abound ; and in the field adjoining, I find Petroselinum segetum. In the woods at the foot of the chalk, principally upon the galt, Silaus pratensis, Senecio tenuifolius, Primula vulgaris, var. caulescens, Daphne Laureola and Habenaria bifolia; and in an

* Sce 'Phytologist,' vol. ii., p. 888. 
arable field upon the sand adjoining, Veronica Buxbaumii plentifully. Prior's wood will afford many an interesting plant, amongst which may be noticed Aquilegia vulgaris (sometimes with white flowers), Orobus tuberosus and Serratula tinctoria.

The chalk-quarries round Guildford will amply repay investigation, and are rich in calcareous plants : in addition to those of the Compton and Wanborough stations will be found Cichorium Intybus, growing in the greatest profusion near St. Catherine's Hill; Allium vineale is located in one spot on the Stoke road; Chenopodium olidum will be found at the foot of an old wall in Quarry-street. Isatis tinctoria grows in the greatest profusion, principally from the fissures on the perpendicular face of the chalk in the Shalford quarry; here also will be found Reseda Luteola; and towards St. Martha's Chapel Brachypodium pinnatum occurs in a disused chalk-pit.

In this neighbourhood Mr. Mill has recorded Fumaria parviflora and Bupleurum rotundifolium (Phytol. i. 40).

The central or great division is that which is occupied by the cultivated portions of the Shanklin sand, in which will be found the following rare or local plants. Smyrnium Olusatrum, by the side of the Shalford road, opposite the park-paling. Dianthus plumarius, in the greatest profusion on an old wall in Shalfordstreet, and on the wall of Westbrook Park. Saponaria officinalis in a hedge-bank near St. Martha's Chapel. Corydalis claviculata, sparingly on St. Martha's Hill, amongst the trees. This delicate plant is abundant in a withy-bed below Perrydean field (Thorncombe-street), also in a wet coppice at Hambledon Heath. Mr. Mill (Phytol. i. 41) records Listera Nidus-avis as growing "in a heathy wood between Guildford and St. Martha's Chapel." Hyoscyamus niger, by the road-side against Stone-bridge wharf, by no means a common plant. Cyperus fuscus, on the margins of Peat pond, on Shalford Common.* Impatiens fulva; by the sides of the Tillingbourne at Chilworth this beautiful exotic is naturalized, growing in the greatest profusion, and is equally abundant by the sides of the Wey to its junction with the 
Thames. The river-sides and adjoining meadows offer a rich treat. The occurrence of Stellaria glauca in marshy meadows at the foot of St. Catherine's Hill, of Cuscuta europæa in an osier-holt by the side of the Wey a little below Guildford, and of Lepidium sativum and Barbarea præcox, upon the banks of the river, has been already recorded by Mr. Mill (Phytol. i. 41 and 64). Nasturtium sylvestre is found by the river-side against Unstead-bridge, and in an adjoining meadow Scabiosa succisa, which also occurs towards Hurtmore Bottom, and near Mungrove. Chrysosplenium alternifolium, intermixed with C. oppositifolium, on a wet hedge-bank near the bridge. There are several other stations for this beautiful plant, as the alder-car on Wood Farm, the Withybeds, in the Deanery meadows, \&c. Medicago maculata grows on the towing-path near Catteshall-bridge, a situation in which I an unable to account for its appearance. In the common meadows will be found OEnanthe silaifolia, and in the ditches $\mathrm{E}$. crocata, Alisma Plantago, Sagittaria sagittifolia, Butomus umbellatus, and several species of Potamogeton, as densus, pusillus, pectinatus, gramineus, perfoliatus ; and in that portion known as Salgaston, Cardamine amara and Menyanthes trifoliata, which also occurs in a meadow higher up the river, and at Bom-moors, Compton. The boggy parts of Hurtmore Bottom will amply repay the labour of investigation. Here several of the marsh plants will be found; among others, Thalictrum flavum, Ribes nigrum, Angelica sylvestris, Samolus Valerandi, Triglochin palustre, Scirpus sylvaticus, and several Carices. Gagea lutea is recorded in the 'Botanist's Guide' as growing in a "meadow near Godalming." I have not been able to verify this information.

The woods surrounding Godalming are rich in botanical rarities. Euonymus europæus, Cornus sanguinea, Campanula Trachelium, Veronica montana, Lamium Galeobdolon and Ruscus aculeatus are common. Cardamine impatiens is abundant for the first two or three years after the clearing of the copsewood. Turritis glabra is sparingly found in the coppices and hedgerows. The declivities of the woods with south and west aspects afford the rare Carex depauperata; the only other station for 
this plant is Charlton, in Kent. On Frith Hill, Lepidium campestre, Dianthus Armeria, Astragalus glycyphyllos, Sedum Telephium and Marrubium vulgare are plentiful. In the corn-fields at the foot will be found Thlaspi arvense, Sisymbrium Sophia and Agrostis Spica-venti.

Upon the tops of the old walls in and about the town several plants have established themselves. Corydalis lutea grows luxuriantly between Meadrow and Farncomb, and sparingly in other situations. Sedum album towards Crown-pits, with S. reflexum, Saxifraga tridactylites, Centranthus ruber and Hieracium murorum. Erigeron acris against the Vicarage, also Linaria Cymbalaria; this beautiful little plant is located in many additional situations.

Many interesting plants are distributed over the central portion of the district. Lepidium Smithii sparingly upon Hascomb roadside, opposite the second mile-stone. Erysimum cheiranthoides in several corn-fields, principally in the direction of Unstead. Cerastium aquaticum in wet situations against Spring Place. Silene anglica, abundant in Perrydean-field, Enton fields, \&c. Hypericum montanum and Geranium lucidum upon most of the hedge-banks; the former in great abundance in the direction of Crown-pits. Rhamnus Frangula, Spring Place, an alder-car on Hambledon Heath ; abundant in a wood near Compton, as stated by Mr. Mill (Phytol. i. 41). Potentilla argentea; this beautiful plant is by no means rare, and will be found upon the slopes near Milden's Wood, also occupying various other situations on the tops of old walls and on hedge-banks. A fine tree of Pyrus communis occurs in a thorny state in a fence upon Hasted Farm. Pyrus aucuparia is plentiful in the hanging woods at Burgate. Bryonia dioica, amongst hedges and thickets in several situations. Dipsacus pilosus, sparingly in a lane near Busbridge Park leading from Holloway Hill, and in a withy-bed towards Milden's Wood. Lactuca muralis, upon the dry walls of Busbridge Park, in the direction of Hambledon. Gnaphalium sylvaticum, var. rectum, has been found very sparingly upon the slopes towards Hurtmore; the same with Iris fœidissima. Verbascum Thapsus and nigrum are generally distributed in the different lanes. An- 
tirrhinum Orontium is a common plant in the corn-fields at Hidestile Farm, Enton \&c. Orobanche minor is abundant in most of the clover-fields; O. major, sparingly in a furze-field on Munstead Farm. Verbena officinalis at the foot of a wall against the bridge and other similar situations. Salvia verbenaca is plentifully distributed over the slopes near Milden's Wood and St. Catherine's Hill. Pulmonaria officinalis, var. angustifolia, occurs by the road-side at Milford, in all probability an outcast from the nursery-ground. Chenopodium olidum, plentiful at the foot of a wall in Farncomb-street, against the chapel. Polygonum dumetorum appears to be by no means rare in coppices and hedgerows; it was first noticed in this vicinity by my friend $\mathrm{Mr}$. Henry Bull, in an alder-car on Manor Farm. P. Bistorta is abundant in a coppice at Tewsley, by the path-side. Orchis Morio, heath on Hoe Farm towards Burgate-woods. Epipactis latifolia, corn-field next Busbridge Coppice, opposite the pond at Thorncomb-street. Carex pseudo-cyperus in an alder-car on Manor Farm, and Bommoors, Compton. Melica uniflora is abundant upon most of the shady hedge-banks \&c. Viscum album is abundant upon most of the fine old whitethorns in Peperharow Park, and in two instances it has established itself upon the Acacia. Several limetrees in Losely Park present a remarkable appearance from the exuberance of this parasite.

The third division comprehends large tracts of barren heath, principally occupying the western and south-western portions of the district, rising in many places into arid elevations, while the plains and hollows afford boggy ground and extensive ponds.

Many delightful rambles may be made in these directions. Witley Lagg is rich in bog-plants:-here may be found Viola palustris, Drosera rotundifolia and intermedia, Epilobium angustifolium, towering with its beautiful and conspicuous spike of rose-coloured flowers; the delicate and interesting Wahlenbergia hederacea is found intermixed with Vaccinium Oxycoccus, Scutellaria minor, Narthecium ossifragum and a plentiful supply of Carices. The numerous morasses on Witley Common will offer similar plants, with the addition of Hypericum elodes, Radiola Millegrana, Peplis Portula, Anagallis tenella and Salix fusca. 
On the drier and elevated portions Teesdalia nudicaulis and Arenaria rubra are plentiful. Cuscuta Epithymum is frequently to be seen in tangled masses, profusely overrunning the Ericæ, Ulex nanus, \&c. Anthemis nobilis is also plentiful, and its perfume is quite overpowering on a warm sumny evening; this plant also occurs upon Highdown Heath, in the vicinity of Pleck Pond, on the margins of which grow Veronica scutellata and Littorella lacustris,-the latter in abundance. The moors skirting Witley Common on the north, will afford, amongst other good things, Carduus pratensis and Eriophorum vaginatum. Upon the margin of Forked Pond, Typha angustifolia is plentiful. Arnoseris pusilla abounds in a gravelly field behind the public house at the Hammer Ponds. The extensive heaths in the direction of Thursley cannot fail to attract attention, and will amply repay the trouble of investigation. In the turf-pits will be found Utricularia minor, Rhynchospora alba, the Eriophori, and a host of bog-plants. Elstead and Puttenham Commons are equally prolific. On the latter, at Cut-mill Pond, immediately bordering upon the parish of Godalming, the interesting addition of Elatine Hydropiper to the southern Flora has been made by $\mathrm{Mr}$. Walter Reeves, for I have no doubt "Cuck mills" is a misprint in the 'Annals and Magazine of Natural History' for Cut Mill, as this is within five miles of Farnham, and I can hear of no such place as Cuck Mills. This very rare plant grows plentifully here, accompanied by $\mathrm{E}$. hexandra, and is invariably submerged, whilst the latter not only grows luxuriantly under the surface, but extends itself upon the sandy margins that are occasionally covered with water. On the margin of the same pond occurs Limosella aquatica, and in a deep morass under the park-paling of Hampton Lodge will be found Potentilla Comarum and Malaxis paludosa.*

Omitting the mention of Phænogamous plants of a less interesting character, I proceed in conclusion to notice the Cryptogamic productions of the district. And from the foregoing description of the geological features and general aspect of the country, it 
may be expected that this branch of the subject will prove equally interesting and extensive. With the exception however of the Filices and Pteroides I have hitherto been unable to devote the necessary attention to this division of the Flora for its satisfactory elucidation. I hope at some future period to be able to supply this desideratum.

The deep rich cuttings and damp woods and shady lanes are particularly favourable for the growth of several species of the Filices. Many of the commoner species grow in the greatest luxuriance, as in the case of Polypodium vulgare, which completely covers the tops and sides of the hedge-banks, preferring to locate on the decayed stumps of trees, and is equally abundant upon the walls at Westbrook \&c.

Polystichum aculeatum and its variety appear to be equally distributed; the dingle towards Hurtmore is a favourable station, as is the case with Lovers' Lane, Farley Hill.

Lastræa Thelypteris occurs very sparingly at Hurtmore Bottom ; hitherto I have only found it with barren fronds. L. Oreopteris sparingly upon the extreme end of Witley Common, by the edge of a wood towards the Hammer Ponds: this beautiful fern grows in the greatest luxuriance in the Devil's Punchbowl at Hindhead. L. Filix-mas is very common in the shady lanes and coppices. The Lastræa multiflora of Newman grows luxuriantly in most of the wet woods. At Cosford, Westbrook, \&c. it abounds at the foot of the alder-stumps and in other similar situations, whilst Athyrium Filix-fœmina generally prefers a more open situation, by the sides of ditches and water-courses that are inclosed with underwood. Asplenium Trichomanes is very common upon the north sides of most of the old walls and bridges in the neighbourhood: on a damp hedge-bank at the back of Farley Hill, the fronds attain a great length. A. Adiantumnigrum abundantly in the same locality, and equally so in several others; it rarely occurs upon any of the walls in this district. A. Ruta-muraria is plentiful upon the garden-wall of Unstead House, and is found more sparingly in other situations. Scolopendrium vulgare will be found in the greatest exuberance in the dingle towards Hurtmore, where the variety with multifid fronds 
frequently occurs. Blechnum boreale is a common plant upon the barren heaths, preferring the sides of the moist ditches. Highdown Heath and Witley Common will afford this plant in the greatest perfection. Pteris aquilina is generally distributed over all the uncultivated ground. Osmunda regalis grows plentifully by the side of Forked Pond next Thursley Common, and sparingly upon Hambledon and Highdown Heaths: but to see it in perfection, the admirer of this elegant species must visit the Devil's Punchbowl, where the fronds attain a great height, and will convey the idea of a truly royal fern. Cattle do not reject the fronds of this species; those at Forked Ponds are annually eaten off by the stock. Botrychium Lunaria is evidently a rare species in this neighbourhood. During the summer of 1840 , I found three plants opposite Pleck Pond on Highdown Heath, since which I have not seen a single specimen growing. Ophioglossum vulgatum appears to be equally scarce; a small patch occurs in the Compton chalk-quarries : a closer investigation on the north side of the Hog's Back will probably yield this plant abundantly. Ceterach officinarum has been found rery sparingly in two situations; my friend Mr. H. Bull first noticed it on Westbrook garden-wall, and a few days subsequently I discovered it on a wall at the Dairy Farm towards Farley Hill : with the exception of the station at Haslemere, noticed in Phytol. i. 1110, no other locality in this county has been recorded for this plant.

Lycopodium clavatum is in great plenty on Highdown Heath, L. Selago very sparingly in the same locality, L. inundatum occurs abundantly in all the wet parts of the different commons. Equisetum Telmateia is generally distributed in the wet parts of the hills; it is abundant upon the hedge-banks against Busbridge Park, in the direction of Tewsley: whilst E. arvense appears to be more generally located higher up in the corn-fields which are inclined to be rather springy. E. palustre, in marshy meadows ; at the back of Shalford, this species occurs abundantly in a wet meadow. E. fluviatile is in most of the ditches, and will be found in the greatest perfection at Hurtmore Bottom, where the turf for fuel has been dug, also at New Pond, and one of the Hammer Ponds. E. sylvaticum: this species I noticed for the first time 
last summer in a wood near Burgate, on the weald clay. E. hyemale: Wanborough Wood very abundant, an interesting addition to the Surrey Flora.

Enumeration of Orders and Species of the Flowering Plants and Ferns of the Godalming Flora.

Orders.

Species.

Orders.

Species

\begin{tabular}{|c|c|c|c|c|c|c|}
\hline Ranunculaceæ & .... & .... & 16 & Grossulariaceæ & .... & $\cdots$ \\
\hline Nymphæасеæ & .... & .... & 2 & Crassulaceæ & .... & .. \\
\hline Papaveraceæ & $\ldots$ & $\ldots$ & 10 & Saxifragaceæ & .... & $\ldots$ \\
\hline Juciferæ $\quad \ldots$. & .... & $\ldots$ & 31 & Araliaceæ $\quad . .$. & .... & .... \\
\hline Resedaceæ & $\ldots$ & .... & 2 & Cornaceæ $\quad . .$. & $\ldots$ & .... \\
\hline Cistaceæ $\quad \ldots$. & .... & .... & l & Umbelliferæ & .... & .... \\
\hline Violaceæ $\quad . .$. & $\ldots$. & .... & 5 & thaceæ & $\ldots$. & .... \\
\hline Droseraceæ.... & $\ldots$ & $\ldots$ & 2 & laceæ & .... & .... \\
\hline сеæ & $\ldots$. & .... & 1 & $x \quad \ldots$ & $\ldots$. & .... \\
\hline eæ .... & .... & .... & 2 & асеæ & .... & .... \\
\hline Caryophyllaceæ & $\ldots$. & $\ldots$ & 28 & 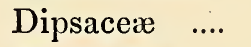 & $\ldots$ & .... \\
\hline Linaceæ $\quad$.... & .... & .... & 2 & ositæ .... & .... & .... \\
\hline Malvaceæ & .... & .... & 3 & nulaceæ & .... & .... \\
\hline Tiliaceæ $\quad$.... & $\ldots$. & .... & 1 & eæ $\quad \ldots$. & $\ldots$ & $\ldots$ \\
\hline icaceæ & .... & $\ldots$ & 8 & & .... & $\ldots$. \\
\hline Acer & $\ldots$ & $\ldots$. & 2 & aceæ.... & $\ldots$ & $\ldots$. \\
\hline еæ.... & .... & .... & 8 & & $\ldots$. & $\ldots$. \\
\hline aceæ & .... & $\ldots$ & 1 & eæ & $\ldots$ & $\ldots$ \\
\hline e.... & .... & $\ldots$ & 1 & laceæ & $\ldots$. & $\ldots$ \\
\hline æ.... & $\ldots$. & .... & 1 & $x \quad \ldots$. & $\ldots$. & .... \\
\hline Rhat & .... & $\ldots$. & 2 & riacex & & $\ldots$. \\
\hline iniferæ & .... & .... & 35 & aceæ & $\ldots$. & $\ldots$ \\
\hline Rosaceæ $\quad \ldots$. & .... & .... & 28 & eæ $\quad \ldots$. & $\ldots$. & $\ldots$. \\
\hline Onagraceæ .... & .... & .... & 8 & aceæ & .... & $\ldots$ \\
\hline eæ & ... & .... & 4 & laceæ & .... & $\ldots$. \\
\hline$æ \ldots$ & .... & .... & 2 & eæ.... & .... & .... \\
\hline taceæ & $\ldots$. & .... & 1 & Plantaginaceæ & .... & .... \\
\hline Portulacaceæ & .... & .... & 1 & Chenopodiaceæ & $\ldots$ & .... \\
\hline Illecebraceæ & $\ldots$ & $\ldots$ & 1 & Polygonaceæ & $\ldots$ & $\ldots$. \\
\hline
\end{tabular}


APPENDIX.

\begin{tabular}{|c|c|c|c|c|c|c|c|}
\hline læaceæ & .... & $\ldots$ & 1 & Liliaceæ & & & \\
\hline anta & $\ldots$ & .... & 1 & amaceæ & & .... & $\ldots$ \\
\hline aceæ & $\ldots$. & .... & & lismaceæ & & .... & \\
\hline .... & .... & $\ldots$ & 6 & & $\ldots$ & .... & $\ldots$ \\
\hline eræ .... & $\ldots$ & .... & 14 & & .... & $\ldots$ & .... \\
\hline & .... & .... & 2 & uncaceæ & $\ldots$ & $\ldots$ & .. \\
\hline ex..... & $\ldots$ & $\ldots$ & 17 & Cyperaceæ & $\ldots$ & .... & .... \\
\hline & $\ldots$ & .... & 2 & Gramineæ & $\ldots .$. & & $\ldots$ \\
\hline & & & & & & & \\
\hline
\end{tabular}

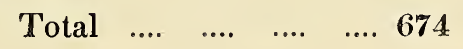

A Comparative Summary of Orders and Species recorded for Godalming, Reigate, and Surrey, omitting mere Varieties, and exchusive of Species and Varieties under Rubus fruticosus. (See Phytol. vol. iii. p. 9.)

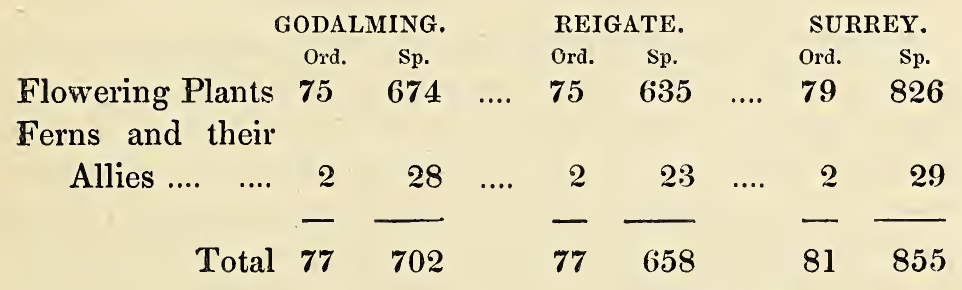

J. D. Salmon.

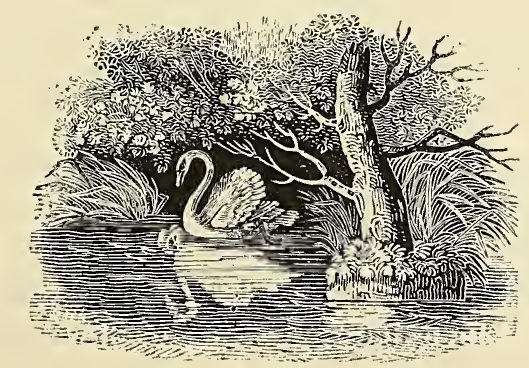




\section{APPENDIX B.}

Account of the Black Canker Caterpillar, which destroys the Turnips in Norfolk. By William Marshall, Esq. Published in the 'Philosophical Transactions' of the Royal Society for 1783. Vol. LXXIII. p. 217.

Among the numerous enemies to which turnips are liable, none have proved more fatal here than the black canker, a species of caterpillar, which in some years have been so numerous as to cut off the farmer's hopes in a few days. In other years, however, the damage has been little, and in others nothing. About twenty years ago the whole country was nearly stripped, and this year it has been subjected to a similar fate. Many thousands of acres, upon which a fairer prospect for a crop of turnips has not been seen for many years, have been ploughed up; and as from the season being now far spent, little profit can be expected from a second sowing. The loss of the farmers individually will be very considerable, and to the country immense.

It was observed in the canker-year above mentioned, that prior to the appearance of the caterpillar, great numbers of yellow flies were seen busy among the turnip-plants; and it was then suspected that the canker was the caterpillar-state of the yellow fly; and since that time it has been remarked, that cankers have regularly followed the appearance of these flies. From their more frequently appearing on the sea-coast, and from the vast quantities which have, I believe, at different times 
been observed on the beach washed up by the tide, it has been a received opinion among the farmers that they are not natives of this country, but come across the ocean, and observations this year greatly corroborate the idea. Fishermen upon the eastern coast declare that they actually saw them arrive in cloud-like flights ; and from the testimony of many, it seems to be an indisputable fact, that they first made their appearance on the eastern coast; and moreover, that on their being first observed, they lay upon and near the cliffs so thick and so languid that they might have been collected into heaps, lying, it is said, in some places two inches thick. From thence they proceeded into the country, and even at the distance of three or four miles from the coast, they were seen in multitudes, resembling swarms of bees. About ten days after the appearance of the flies, the young caterpillars were first observed on the under side of the leaves of the turnip, and in seven or eight days more the entire plants, except the stronger fibres, were eaten up. A border under the hedge was regularly spared until the body of the inclosure was finished; but this done, the border was soon stripped, and the gateway, and even the roads have been seen covered with caterpillars, travelling in quest of a fresh supply of turnips ; for the grasses, and indeed every plant, except the turnip and the charlock (Sinapis arvensis), they entirely neglect, and even die at their roots, without attempting to feed upon them. This destruction has not been confined within a few miles of the eastern coast, but has reached more or less into the very centre of the county. The mischief, however, in the western parts of Norfolk, and even on the north coast, has been less general, but I am afraid it may be said, with a great deal of truth, that one half of the turnips in the county have been cut off by this voracious animal.

A circumstance so discouraging to industry and injurious to the public at large, will, I flatter myself, be thought a sufficient apology for troubling you with a relation of it, and for my taking the liberty of sending you a male and female fly, also one of the animals in its caterpillar, and one which is in its chrysalis state, for your inspection, hoping that the public may become 
acquainted with the means of preventing in future so great a calamity.

Lest the flies may become disfigured in travelling, it may be prudent to say that their wings are four ; that their antennæ are clubbed, and about one-third the length of their body, each being composed of nine joints, namely, two next the head, above which two there is a joint somewhat longer than the rest, and above this six more joints, similar to the two below; that near the point of the tail of the female there is a black speck, outwardly fringed with hair, but which, opening longitudinally, appears to be the end of a case, containing a delicate point or sting, about one-twentieth of an inch in length, which on a cursory view appears to be a simple, lanceolated instrument, with a strong line passing down the middle, and serrated at its edges, but on a closer inspection, and by agitating it strongly with a point of a needle, it separates into three one-edged instruments, hanger-like as to their general form, with a spiral line or wrinkle winding from the point to the base, making ten or twelve revolutions, which line, passing over their edges, gives them some appearance of being serrated.

By the help of these instruments, I apprehend, the female deposits her eggs in the edge of the turnip-leaf (or sometimes, in the nerves or ribs on the under surface of the leaf); thus far I can say, and I think with a considerable degree of certainty, that having put some fresh turnip-leaves into a glass containing several of the male and female flies, I perceived (by means of a simple magnifier) that one of the females, after examining attentively the edge of the leaf, and finding a part which appeared to me to have been bitten, unsheathed her instruments, insinuated them into the edge of the leaf, and having forced them asunder, so as to open a pipe or channel between them, placed her pubes (the situation of which from repeated and almost incessant copulations I had been able to ascertain precisely, and to the lower part of which these instruments seem to be fixed) to the orifice, and having remained a few seconds in that posture, deliberately drew out the instruments (which the transparency of the leaf held against a strong light afforded me an opportunity 
of seeing very plainly) and proceeded to search for another convenient place for her purpose. The caterpillar has twenty feet (six of its legs being of considerable length, the other fourteen very short), and in its first stage is of a jetty black, smooth, as to privation of hair, but covered with innumerable wrinkles. Having acquired its full size, it fixes its hinder parts firmly to the leaf of a turnip, or any other substance, and breaking its outer coat or slough near the head, crawls out, leaving the skin fixed to the leaf, \&c. The under coat, which it now appears in, is of a bluish or lead-colour, and the caterpillar is evidently diminished in its size. In every respect it is the same animal as before, and continues to feed on the turnips for some days longer: it then entirely leaves off eating, and becomes covered with a dewy moisture, which seems to exude from it in great abundance, and appearing to be of a glutinous nature, retains any loose or pliant substance which happens to come in contact with it, and by this means alone seems to form its chrysalis coat. One I find laid up in the fold of a withered turnip-leaf (that which I have the honour of enclosing you) was, among six others, formed by putting common garden mould to them while they were in the exudatory state above described.

From the generic characters of the fly I conclude it to be a Tenthredo of Hill ; but whether that voluminous author be sufficiently accurate, or whether, from being an almost entire stranger to Natural History, I may or may not sufficiently understand my book, I must beg leave to submit to your superior knowledge of the subject.

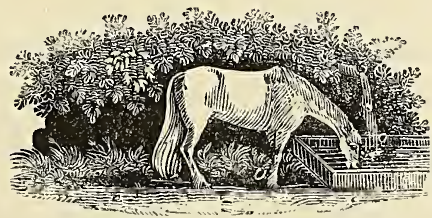




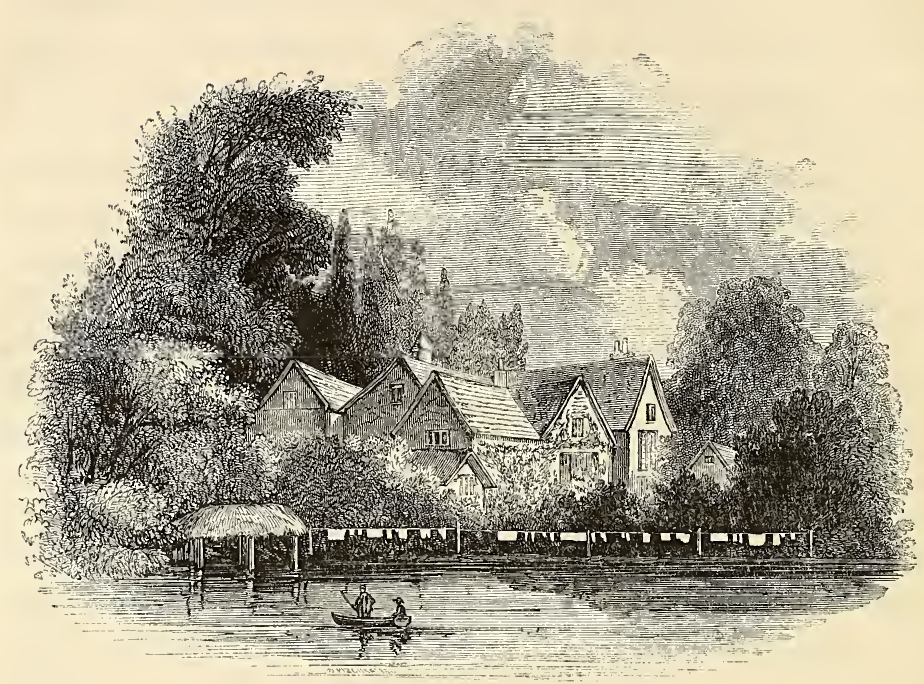

HATCH FROM THE POND.

\section{APPENDIX C.}

An Outline of the Ornithology of Godalming, in the County of Surrey; with brief Records of the Occurrence of some of the Rarer Birds. By Edward Newman.

I HAVE introduced above a very faithful representation of Hatch, so long the residence of Mr. Kidd: it was here that he cultivated Ornithology so successfully; and 1 was at that time a very frequent visitor to his bird-room, and spent many of the happiest hours of my boyhood in receiving information in that much loved apartment. For many years every rare bird shot within twenty miles of Godalming was brought to Waring Kidd, at Hatch, and consequently the opportunity he possessed of acquiring an exact knowledge of the Ornithology of the district could not be surpassed, and has rarely been equalled. 
Circumstances seeming to make it desirable that this part of the work should be compiled by myself, I have endeavoured to render it as complete as possible, by incorporating all the records made by my respected friend and relative with the more recent observations obligingly supplied by Mr. Salmon, whose acquirements as an ornithologist are well known and justly appreciated by his fellow naturalists.

I have obtained some additional information from Mr. Stafford, gleaned a few paragraphs from the 'Zoologist,' and added one or two observations of my own. The arrangement is also somewhat altered from that usually adopted, as I considered a purely scientific arrangement, revealing so imperfectly the history of the birds enumerated, insufficient for my purpose. For the same reason I have employed English in preference to Latin names, as the information which I wish to diffuse is designed for the general reader rather than the man of science. I propose dividing the birds which have been observed in the neighbourhood into five groups, distinguished solely by the certainty, duration, season, or uncertainty of their stay. These groups I shall call

\author{
Resident Natives. \\ Migrant Natives. \\ Winter Visitors. \\ Passing Visitors. \\ Occasional Visitors.
}

\title{
1. Resident Natives.
}

These birds not only nest in the immediate neighbourhood of Godalming, but remain there throughout the year, the food on which they live being procurable in winter as well as summer, and therefore their existence during frost not being contingent on a southward migration. They are fifty-seren in number, and of these it has been ascertained that several experience an increase or diminution in their number at the usual periods of vernal and autumnal migration. It seems scarcely necessary to 
add that the pheasant and red-legged partridge are not aboriginal natives, but perfectly naturalized inhabitants.

\begin{tabular}{|c|c|c|}
\hline Kestrel & Skylark & Green Wood- \\
\hline Sparrow Hawk & Woodlark & pecker \\
\hline Long-eared Owl & Common Bunting & Great Spotted \\
\hline Barn Owl & Yellowhammer & Woodpecker \\
\hline Tawny Owl & Black-headed & Lesser Spotted \\
\hline Missel Thrush & Bunting & Woodpecker \\
\hline Song Thrush & House Sparrow & Common Creepe \\
\hline Blackbird & Tree Sparrow & Wren \\
\hline Hedgesparrow & Chaffinch & Nuthatch \\
\hline Robin & Greenfinch & Kingfisher \\
\hline Stonechat & Hawfinch & Ring Dove \\
\hline Dartford Warbler & Goldfinch & Pheasant \\
\hline Golden-crested & Linnet & Black Grouse \\
\hline Regulus & Bullfinch & Partridge \\
\hline Great Tit & Starling & Red-legged Part \\
\hline Blue Tit & Raven & ridge \\
\hline Coal Tit & Crow & Peewit \\
\hline Marsh Tit & Rook & Water Rail \\
\hline Long-tailed Tit & Jackdaw & Moorben \\
\hline Pied Wagtail & Magpie & Coot \\
\hline Meadow Pipit & Jay & Little Grebe \\
\hline
\end{tabular}

Hawfinch. This bird has been frequently observed in thick coppices in Westbrook Park and in Eashing Park. It seems to feed on berries and seeds fallen to the ground, and flies up into the highest trees on the least alarm. It certainly breeds in the neighbourhood of Godalming. - William Stafford. A pair of hawfinches built their nest in the garden at Peperharow this last spring [1848], but unfortunately, when the young were nearly fledged, they were destroyed as was supposed by a cat, an addled egg only being left. - J. D. Salmon. Mr. Henry Doubleday has observed that the hawfinch feeds principally on the seeds of the hornbeam, but also eats haws, laurel-berries, \&c., and in summer makes great havoc amongst green peas. 


\section{Migrant Natives.}

These birds nest within the district, and are therefore strictly natives, but regularly leave it before winter: they are thirtyone in number.

$\begin{array}{lll}\begin{array}{l}\text { Hobby } \\ \text { Red-backd. Shrike }\end{array} & \text { Blackcap } & \text { Cuckoo } \\ \text { Spot }^{\text {d. }} \text { Flycatcher } & \text { Whitethroat } & \text { Swallow } \\ \text { Redstart } & \text { Lesser White- } & \text { Sartin } \\ \text { Whinchat } & \text { throat } & \text { Swift } \\ \text { Wheatear } & \text { Wood Warbler } & \text { Nightjar } \\ \text { Grasshopper } & \text { Willow Warbler } & \text { Stock Dore } \\ \quad \text { Warbler } & \text { Chiffchaff } & \text { Turtle Dove } \\ \text { Sedge Warbler } & \text { Ray's Wagtail } & \text { Quail } \\ \text { Reed Warbler } & \text { Tree Pipit } & \text { Great Plover } \\ \text { Nightingale } & \text { Wryneck } & \text { Landrail }\end{array}$

House Martin. The great body of the martins that visit this district, instead of attaching their nests under the eaves of the houses in this town, have resorted to the extensive chalk-quarries in the vicinity of Guildford and Wanborough, for the purpose of nidification. At the latter place I have observed no less than 150 nests attached to the face of the rock under the projecting ledges. There they nestle in perfect security. The material they make use of in constructing their nests being powdered chalk, it is with some difficulty that they are to be distinguished on the face of the rock. Now and then a belt of darker material intervenes in their otherwise marbled masonry.- $J . D$. Salmon.

\section{Winter Visitors.}

Under this head I comprehend those birds which do not nest within the district, but which arrive after that process has been accomplished farther to the north. The number of such birds is twenty-nine, and three of these, the snipe, wild duck and teal, 
occasionally so far depart from their usual habit, as to rear their young within the county: such instances, however, are the exceptions, and not the rule, and do not entitle these three birds to rank as Resident Natives.

$\begin{array}{lll}\text { Merlin } & \text { Golden Plover } & \text { Shoveler } \\ \text { Short-eared Owl } & \text { Woodcock } & \text { Gadwall } \\ \text { Fieldfare } & \text { Common Snipe } & \text { Pintail Duck } \\ \text { Redwing } & \text { Jack Snipe } & \text { Wild Duck } \\ \text { Gray Wagtail } & \text { Gray-legd. Goose } & \text { Garganey Duck } \\ \text { Mountain Finch } & \text { White-fronted } & \text { Teal } \\ \text { Lesser Redpole } & \text { Goose } & \text { Wigeon } \\ \text { Siskin } & \text { Hooper } & \text { Pochard } \\ \text { Crossbill } & \text { Bewick's Swan } & \text { Tufted Duck } \\ \text { Hooded Crow } & \text { Com. Shieldrake } & \text { Golden Eye }\end{array}$

Mountain Finch. This bird appeared in immense numbers near Farnham, during the past winter, 1842-3.-Jas. Lewcock, Zool. 188.

Siskin. The siskin may be frequently seen in the winter in great abundance in the alders on the covers near Catteshall, close to the river.-Waring Kidd.

Common Crossbill. Four or five years ago the Scotch firs in the Holt Forest were cut out to allow more room for the growth of the young oaks : when the trees were thrown, four nests of the crossbill were found in their topmost forks; the nests and eggs had much the appearance of those of the greenfinch.-James Lewcock, Zool. 189.

White-fronted Goose. A few days since three white-fronted or laughing wild geese were shot on the estate of James Gregg, Esq., at Liphook, 2nd February, 1841.-Provincial Paper.

Tufted Duck. Two out of a flock of five of the tufted duck were shot at Milford, in January, 1841.-Rev. W.W. Spicer.

\section{Passing Visitors.}

Ring Ousel Com. Sandpiper Green Sandpiper

Ring Ouzel. The ring ouzel is frequently found on Hindhead, and other high, sandy grounds in the neighbourhood, in 
spring and autumn. - Waring Kidd. At Aldershot, a village near Farnham, the ring ouzels appeared in some abundance on the 8th of September last; they remained about the neighbourhood till the 19th, after which none were seen. In a few specimens that were shot, the white was much more observable than in those birds which were killed when they passed this place in their spring migration.-T. Mansell, Zool. 444. The migration of the ring ouzel in spring and autumn, as mentioned by White, is still observed.--James Lewcock.

This bird comes from its native haunts in the north at the end of September or beginning of October, and returns thither in the spring: it does not stay on either passage more than from ten to fourteen days.

Common Sandpiper I consider a Passing Visitor: the same remarks as applied to the ring ouzel are applicable to this species; in confirmation see in Mr. Bartlett's Ornithology of Kent, Zool. p. 265, Mr. Gurney's Norfolk Birds, Zool. p. 1324, and for additional information on the migratory movements see Zool. pp. 927, 1129 and 1132. I do not think this bird breeds further south than Yorkshire. I find I have the following entries of its periodical arrival at Thetford, Norfolk :-

Spring migration, May 23, 1834. *May 17, 1836.

Autumnal do. Aug. 11, 1834. Aug. 16, 1835.

\section{-J. D. Salmon.}

Green Sandpiper. The green sandpiper is frequently met with near Godalming.- $W . K$. I have every reason to believe the green sandpiper breeds in Surrey, having seen a very young one shot near Godalming, with the primaries incompletely developed. - E. Blyth in Mag. Nat. Hist. 2nd Series, i. 605. I saw a flock, consisting of eight individuals, at the Hammer Ponds, on the 16th September, 1845. This bird must properly be considered a Passing Visitor.-J. D. Salmon.

\section{Occasional Visitors.}

It seems to me that the foregoing birds, one hundred and twenty in number, are all that can fairly be considered as hav-

* Not observed in the spring of 1835 . 
ing any connexion with the district under consideration, but a very considerable list, comprising seventy-five distinct species, has been added, of birds which have visited the neighbourhood at uncertain seasons and in unequal numbers: it will be perfectly evident to the naturalist that a considerable number being purely oceanic, must be driven so far inland by accidental, although perhaps natural, occurrences, and that they must be regarded as altogether aliens, a term still more applicable to those exotic birds which have on one or two occasions been observed within the district.

\begin{tabular}{|c|c|c|}
\hline Osprey & Dottrell & Brent Goose \\
\hline Peregrine Falcon & Ringed Plover & Garganey Duck \\
\hline Kite & Gray Plover & Common Scoter \\
\hline Com. Buzzard & Sanderling & Scaup Duck \\
\hline Honey Buzzard & Oyster-catcher & Smew \\
\hline Marsh Harrier & Common Bittern & Goosander \\
\hline Hen Harrier & White Stork & Red-neck'd Grebe \\
\hline Montagu's Harrier & White Spoonbill & Eared Grebe \\
\hline Little Owl & Glossy Ibis & Great Northern \\
\hline Great Gray Shrike & Curlew & Diver \\
\hline Pied Flycatcher & Com. Redshank & Black-throated \\
\hline Colden Oriole & Greenshank & Diver \\
\hline Bearded Tit & Avocet & Red-throat'd Diver \\
\hline Bohemian Wax- & Black-wing'd Stilt & Little Auk \\
\hline wing & Black-tailed God- & Com. Cormorant \\
\hline Rock Pipit & wit & Green Cormorant \\
\hline Snow Bunting & Ruff & Gannett \\
\hline Cirl Bunting & Great Snipe & Common Tern \\
\hline Mealy Redpole & Curlew Sandpiper & Lesser Tern \\
\hline Twite & Knot & Black Tern \\
\hline Two-barred Cross- & Dunlin & Black-head'd Gull \\
\hline bill & Spotted Crake & Kittiwake \\
\hline Nutcracker & Little Crake & Common Gull \\
\hline Ноорое & Gray Phalarope & Lesser Black- \\
\hline Bee-eater & Red-necked Pha- & backed Gull \\
\hline Rock Dove & larope & Herring Gull \\
\hline
\end{tabular}




\section{Great Black- Richardson's Skua Storm Petrel backed Gull Fork-tail Petrel}

Additional Remarks concerning Occasional Visitors.

Osprey. An osprey was shot at Frensham Pond in 1772, while it was sitting on the handle of a plough devouring a fish. -White's Selborne. Ospreys shot at the Pudmoors, Frensham Pond, \&c., have not unfrequently been brought to me: I have stuffed no less than seven.-Waring Kidd. About the end of September, 1843, an osprey was seen in several different places near here, hovering over Frensham and other ponds. I am not aware that this specimen was killed, but about three years ago $I$ obtained a specimen which measured three feet across the expanded wings. - T. Mansell, Zool. 443.

Peregrine Falcon. A specimen shot at Hindhead was brought to me.-Waring Kidd. A specimen was caught in a rabbit-trap at Eashing.-Edward Newman. A specimen shot at Bentley, in 1844, is now in the possession of S. Nicholson, Esq.-James Lewcock.

Kile. The name of this bird occurs, on the authority of $\mathrm{Mr}$. Mansell, in a list of the birds of Farnham by the late James Lewcock.-J. D. Salmon.

Common Buzzard. The common buzzard is sometimes very abundant.-Waring Kidd.

Honey Buzzard. Two specimens of the honey buzzard have been shot in Shillinglee Park, the seat of Lord Winterton. Waring Kidd.

Marsh Harrier. Three specimens, shot near Godalming, have been stuffed by me.-Waring Kidd.

Hen Harrier. Several of this bird have been stuffed by me. -Waring Kidd.

Montagu's Harrier. Several of this bird have been stuffed by me.-Waring Kidd.

Little Owl. A single specimen was shot in Shillinglee Park. -Waring Kidd.

Greal Gray Shrike. This bird has been occasionally seen on the higher grounds: I have stuffed a single specimen.- 
Waring Kidd. One shot at Frensham, from the top of a tall elm tree, 1835, is in my possession; another was shot at Ash.James Lewcock. A female was shot in December, 1843, at Elsted.-J. D. Salmon.

Pied Flycalcher. One was shot in my father's orchard, at Hatch, many years ago.-Waring Kidd. A specimen was shot at Witley Park, in May, 1836.-William Stafford.

Golden Oriole. A specimen of the golden oriole was seen near the town of Godalming in the year 1833. - Waring Kidd.

Bearded Tit. Specimens have been brought to me for preserving from Elsted, and also from Hampton Lodge, the seat of H. L. Long, Esq.-Waring Kidd.

Bohemian Waxwing. A single specimen of this bird was seen near Godalming in 1832.-Edward Newman.

Rock Pipil. A specimen has been shot at Tilford. - James Lewcock.

Snow Bunting. I have a specimen shot at Hale: it was in company with skylarks._James Lewcock.

Cirl Bunting. The cirl bunting has occasionally been shot in the neighbourhood of Godalming, and brought me to stuff.William Stafford.

Mealy Redpole. Inserted on the authority of Waring Kidd. - E. Newman.

Twite. Inserted on the authority of Waring Kidd. - $E$. Newman.

Two-barred Crossbill. A male specimen of this bird was shot in Unsted Wood, and is now in the possession of H. Nicholson, Esq., of Waverley Abbey.-J. D. Salmon. It appears there has been a mistake in supposing the white-winged crossbill of North America to be identical with the Europæan bird described by Nilsson, Brehm, Gloger, Jenyns, Gould, Eyton and Yarrell, which is the Loxia bifasciata of Nilsson, and the Loxia tænioptera of Gloger. Although there are many instances of the occurrence of this bird in Britain, this is the earliest record under its proper name.-Edward Newman.

Nutcracker. A specimen seen by the late Mr. Robert 
Haines, in Peperharow Park, the seat of Viscount Midleton, a second by myself near Guildford.-Waring Kidd.

Hoopoe. A specimen of the hoopoe was shot in the summer of 1838, by Mr. Richard Sturt, at Frensham, whilst pecking at an ant hill, where it had been previously observed. Another specimen was shot among some sheep near Liphook, on the 22nd April, 1845.-James Lewcock.

Bee-eater. A single specimen of this beautiful bird was shot in Mr. Robert Moline's garden in Church Street, and is now in possession of that gentleman.-Waring Kidd.

Rock Dove. The rock dove is occasionally met with in the neighbourhood.-Waring Kidd.

Dottrell. Inserted on the authority of Mr. Lewcock.- J. $D$. Salmon.

Ringed Plover. A few specimens of the ringed plover have been shot at Frensham Pond.-W. $K$.

Gray Plover. A few specimens of the gray plover have been shot at Godalming.-W. $K$.

Sanderling. The sanderling has been shot not unfrequently at Frensham Pond.- $W . K$.

Oyster-catcher. I have stuffed four specimens of the oystercatcher shot in the neighbourhood of Godalming.- $W . K$. On the 23rd of March, 1845, I shot a specimen of the oyster-catcher on the banks of the river Wey, near Guildford.-F. A. Chennell, Zool. 1212.

Common Bittern. Inserted on the authority of Waring Kidd. - E. Newman. A specimen killed at Hampton Lodge, Jan. 1848, was presented to the Surrey Natural History Society, by H. L. Long, Esq.-J. D. Salmon.

White Stork. Inserted on the authority of Mr. Lewcock.J. D. Salmon.

White Spoonbill. On the 24th of October, 1844, an uncommon-looking bird was noticed by the person who rents Frensham Pond wading in shallow water. He succeeded in shooting it, and it proved to be the white spoonbill, a young bird of the year, the crest being wanting. - James Lewcock, Zool. 878.

Glossy Ibis. A single specimen of the glossy Ibis was shot 
at Whitemore Pond, near Guildford, in May, 1833.-William Stafford.

Curlew. The curlew has been shot on the moors near Frensham.-W. $K$.

Common Redshank. Inserted on the authority of Mr. Lewcock.-J. D. Salmon.

Greenshank. A single specimen of the greenshank was shot at Hampton Lodge.-W. $K$.

Avocet. Inserted on the authority of Mr. Mansell. - J. D. Salmon.

Black-winged Stilt. I find no notice of this bird since the very interesting one published in White's Selborne: it is as follows:- "In the last week of last month, five of those most rare birds, too uncommon to have obtained an English name, but known to naturalists by the terms of himantopus, or loripes, and Charadrius himantopus, were shot upon the verge of Frensham Pond, a large lake belonging to the Bishop of Winchester, and lying between Wolmer Forest and the town of Farnham, in the county of Surrey. The pond-keeper says there were three brace in the flock; but that, after he had satisfied his curiosity, he suffered the sixth to remain unmolested. One of these specimens I procured, and found the length of the legs to be so extraordinary, that, at first sight, one might have supposed the shanks had been fastened on to impose on the credulity of the beholder: they were legs in caricatura; and had we seen such proportions on a Chinese or Japan screen, we should have made large allowances for the fancy of the draughtsman. These birds are of the plover family, and might, with propriety, be called the stilt-plovers. Brisson, under that idea, gives them the apposite name of l'echasse. My specimen, when drawn, and stuffed with pepper, weighed only four ounces and a quarter, though the naked part of the thigh measured three inches and a half, and the legs four inches and a half. Hence we may safely assert, that these birds exhibit, weight for inches, incomparably the greatest length of legs of any known bird. The flamingo, for instance, is one of the most long-legged birds, and yet it bears no manner of proportion to the himantopus; 
for a cock flamingo weighs, at an average, about four pounds avoirdupoise; and his legs and thighs measure usually about twenty inches. But four pounds are fifteen times and a fraction more than four ounces and one quarter; and if four ounces and a quarter have eight inches of legs, four pounds must have one hundred and twenty inches and a fraction of legs, viz., somewhat more than ten feet, - such a monstrous proportion as the world never saw! If you should try the experiment in still larger birds, the disparity would still increase. It must be matter of great curiosity to see the stilt-plover move; to observe how it can wield such a length of lever with such feeble muscles as the thighs seem to be furnished with. At best, one should expect it to be but a bad walker: but what adds to the wonder is, that it has no back toe. Now, without that steady prop to support its steps, it must be liable, in speculation, to perpetual vacillations, and seldom able to preserve the true centre of gravity."-White's Selborne, Letter xci. addressed to the Hon. Daines Barrington.

Black-tailed Godwit. Inserted on the authority of Mr. Lewcock.-J. D. Salmon.

Ruff. A considerable flight of these birds, apparently all of them young ones, was found near Godalming on the 20th of August, 1836.-W. $K$.

Great Snipe. Inserted on the authority of Mr. Lewcock.J. D. Salmon.

Curlew Sandpiper. Inserted on the authority of Mr. Mansell._J. D. Salmon.

Knot. A specimen was shot in the neighbourhood of the Pudmoors within the last few days, December 25, 1844.-J. D. Salmon.

Dunlin. Inserted on the authority of Mr. Lewcock. $-J . D$. Salmon.

Spotled Crake. Inserted on the authority of Mr. Lewcock. 一J. D. Salmon.

\section{Little Crake.}

Gray Phalarope. The gray phalarope has been shot occasionally about Godalming and Guildford.- $W . K$. A male 
bird was picked up near the bridges, Godalming, by $\mathrm{Mr}$. Thomas Stedman, Nov. 30, 1846. About the same time six individuals were shot at Woking, and sent to Mr. Apark, Guildford, to preserve.-J. D. Salmon.

Red-necked Phalarope. Inserted on the authority of $\mathrm{Mr}$. Mansell.-J. D. Salmon.

Brent Goose. A specimen of the brent goose shot at Wipley Farm, three miles below Bramley, was presented to the Surrey Natural History Society by Mr. Eager.-J. D. Salmon.

Garganey Duck. Inserted on the authority of Mr. Mansell. -J. D. Salmon.

Common Scoter. A specimen of this rare duck was shot on a pond near the canal, at Farnham, on the 2nd of November, 1844.-T. Mansell, Zool. 455.

Scaup Duck. A fine specimen of the scaup duck was shot on a large piece of water, close to Milford House, near Godalming, Surrey, on the 8th of December, 1846. - Rev. W. W. Spicer, Zool. 1641.

Smew. Inserted on the authority of Mr, Mansell. $-J . D$. Salmon.

Goosander. Inserted on the authority of Mr. Lewcock.-J. D. Salmon.

Red-necked Grebe. Inserted on the authority of Mr. Mansell. -J. D. Salmon.

Eared Grebe. A pair of this bird were shot on Forked Pond, by Peperharow Park. See page 16.

Great Northern Diver. Two specimens of this bird have been shot on Frensham Pond and one on Old Pond. $-W . K$.

Black-throated Diver. The black-throated diver has been occasionally shot on Frensham Pond.-W. $K$.

Red-throated Diver. Eight individuals of this species were discovered on the ground at Clandon, 14th Oct. 1848. They appeared to be much exhausted: one was shot, and proved to be a young bird of the present year.-J. D. Salmon.

Little Auk. Inserted on the authority of Mr. Lewcock.-J. D. Salmon. 
APPENDIX.

Common Cormorant. Inserted on the authority of Mr. Lewcock.-J. D. Salmon.

Green Cormorant. Inserted on the authority of Mr. Mansell. -J. D. Salmon.

Gannett. An immature specimen of the gannett was taken alive in the parish of Ash during the autumn of 1847.-J. D. Salmon.

Common Tern. This bird has been frequently shot at Frensham Pond.-W. $K$.

Lesser Tern. The lesser tern occurs at Frensham Pond, and has been occasionally killed there.-W. $K$.

Black Tern. The black tern has been shot at Frensham Pond.-W. $K$.

Black-headed Gull. Inserted on the authority of W. Kidd. -E. Newman.

Kittiwake. I shot a specimen of the kittiwake on the pond at Hatch.-W. $K$.

Common Gull. Inserted on the authority of W. Kidd. $-E$. Newman.

Lesser Black-backed Gull and Herring Gull. These occasionally pass over this district previously to stormy weather occurring. I have several times seen small parties of from three to five, but have been unable to decide to which species they belong; probably to both.-J. D. Salmon.

Great Black-backed Gull. Inserted on the authority of $\mathrm{Mr}$. Mansell.-J. D. Salmon.

Richardson's Skua. From a local list.

Fork-tail Petrel. A specimen of the fork-tail petrel was shot on Hindhead, near Liphook, and stuffed by me.-William Stafford. A specimen was picked up dead in the neighbourhood of Haslemere, 21st November, 1840. During the last week some fork-tail petrels were found dead in the neighbourhood of Dunsfold and Haslemere, 2nd February, 1841. - Provincial Paper.

Storm Petrel. Several specimens of the storm petrel or Mother Carey's chicken, have been killed near Godalming, and stuffed by me.- $W$. $K$. 


\section{Summary of the Birds of Godalming.}

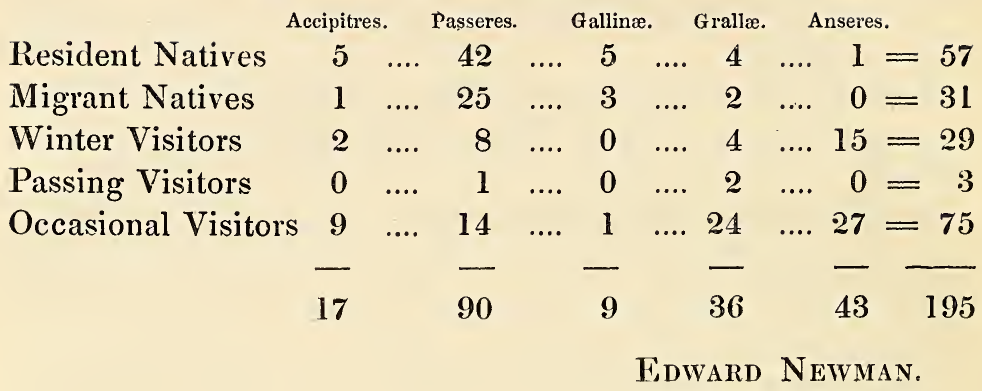

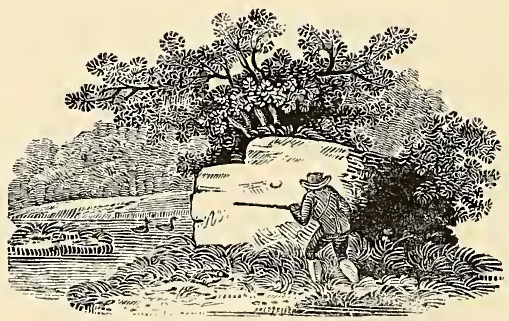


Also published by Mr. Van Voorst,

A FAMILIAR INTRODUCTION

\section{HISTORY OF INSECTS.}

\section{Br EDWARD NEWMAN.}

In cloth boards, $8 v o ., 12 s$.

This work is illustrated by a profusion of engravings, executed in the first style of the art, from the author's own drawings on the wood. It is divided into four parts. The first gives a detailed account of the habits and manners of the most interesting insects, and a description of their wonderful transformations. The second treats of capturing, killing and preserving insects, and of constructing cabinets: the most ample details are given, and the author has taken especial pains to explain the most expeditious modes of killing insects, in order to inflict no unnecessary pain on the insects themselves, and also to save the feelings of the humane and kind-hearted. In the third part the author describes, in an easy and popular manner, the structure of insects, using language which all may understand, yet never deviating from scientific accuracy. The fourth part gives a sketch of the classification of insects; and the work concludes with an Alphabetical Index, each technical word having an explanation as well as reference.

\section{(0)}

"The work throughout is clearly written, in many parts with animation and spirit-the result of an active mind distinctly perceiving what it intends to convey."-Spectator.

"A volume which is likely to be very serviceable to the beginner. It is very carefully illustrated by numerous and well-executed wood engravings." Morning Herald.

"This volume, one of the best familiar introductions to Entomology we have met with, we recommend to those desirous of acquiring accurate elementaiy information on the history, general physiology, classification, and mode of preserving insects."-Professor Jameson's Journal.

"We have here a complete popular treatise. It is a kind of first book on Entomology, but may answer every purpose to nine-tenths of students."-Tait's Edinburgh Magazine.

"A very acceptable mixture of the dulce et utile. Mr. Newman does not take too much knowledge for granted, but, beginning at the beginning, fairly illustrates his subject. We cordially recommend his volume not only to entomological students, but to all lovers of animate Nature."-Literary Gazette.

"The charm of this volume is, that it is written in a frank and explanatory spirit, which will be quite as intelligible and captivating to a child as to a man. There are no mysteries of science buried under ominous italics in its pages." Atlas.

"The best popular guide to the study of Entomology is Newman's ' Familiar Introduction to the History of Insects.' "-Westminster Review. 


\section{III. \\ A HISTORY OF BRITISH FERNS,}

E D W A R D NEW M A .

In cloth boards, 8vo., price 25 s.

This work is illustrated by one hundred and fifty-eight engravings, which are carefully executed by some of our first artists, from the author's own drawings on the wood, and consist of studiously accurate figures of every species and variety of Fern found in Great Britain.

The IFquisetaceæ, Iycopodiaceæ, \&c., are included.

\section{OPINIONS OF THE PRESS.}

"It is a great gratification to have it in our power most cordially to recommend this work to all those who desire to obtain a knowledge of our British Ferns, as one which, in accuracy of observation, elaborateness and clearness of description, and beauty of illustration, does not possess its equal." $-M r . B a-$ bington, in Annals of Natural History.

"It is just such books as this which render Natural History so attractive to everybody who finds other pleasures in a country life besides hunting, coursing, fishing and shooting."-Professor Lindley, in Gardener's Chronicle.

"To every lover of British Botany we cordially recommend $\mathrm{Mr}$. Newman's volume."-Magazine of Natural History.

"The clear account of species, and the popular suggestions for their culture, contained in this volume, justify our cordial recommendation of its pages."Atlas.

"The embellishments of this pretty volume are executed with equal good taste and skill."-Gentleman's Magazine.

"A valuable present to the lady botanist."-Loudon's Gardener's Magazine.

"No lady in the country ought to be without it."-Gardener's Gazette.

"Those who are desirous of acquiring an intimate acquaintance with our native species of this beautiful and interesting order of plants, cannot do better than consult Mr. Newman's "History of British Ferns." -Mr. Ward, on the Growth of Plants in Closely Glazed Cases.

\section{IV. \\ A CATALOGUE OF BRITISH FERNS, INCLUDING}

THE EQUISETACEE AND LYCOPODIACEÆ:

INTENDED FOR LABELS.

B Y E D W A R NEW M N .

In paper cover, price $6 d$.

$\mathrm{V}$.

A LIST OF

B RITISH ORNITHOLOGY,

Bcing a single shect containing the name of every British Bird, and intended to facilitate the exchange of Specimens and Eggs.

Price 2s. foz. 


\section{VI. \\ THE ZOOLOG IST:}

\section{A POPULAR JOURNAL OF FIELD NATURAL HISTORY.}

On the 1 st of every Month, price 1 s.

From his earliest boyhood the editor has been an admirer of White's 'Natural History of Selborne,' and has often longed for a collection of observations on similar subjects, written in a similar strain and spirit; not indeed, like White's, confined to one observer and one spot, but having no limit either in number of observers or range of observations : with this view he established 'The Zoologist,' and the good feeling with which it has been received is a sufficient proof that its plan is acceptable to "out-of-door naturalists" - those who delight in observing the manners and habits, the private lives, the migrations, movements, nests, food and young of animals.

Atkinson, Rev. J.C., B.A. Gurney, S. jun., Esq. Norman, George, Esq.

Baird, W., M.D.

Haliday, A.H., Esq.M.A. Parsons, C., Esq., F.L.S.

Banister, Rev. J.D., M.A. Harrison, Rev.H.R.,M.A. Patterson, Robert, Esq.

Barclay, J. Gurney, Esq. Haslam, S. H., Esq.

Bell, Thos., Esq., F.R.S. Hepburn, A., Esq.

Borrer, W., Esq., F.L.S. Heppenstall, Jolnn, Esq.

Bree, C. R., Esq., F.L.S. Hewitson, W. C., Esq.

Bree, Rev. W. T., M.A. Holme, Frederick, Esq.

Bromfield, W. A., M.D., Hore, Rev. W. S. F.L.S.

Bull, Henry, Esq.

Horsley, Rev. F. W.,M.A. Salter, T. B., Esq., M.D., Hussey, Rev. Arthur

Burlingham, D. C., Esq. Jerdon, Archibald, Esq.

Bury, Rev. C. A.

Chennell, F. A., Esq.

Clifford, Rev. Frank

Couch, J., Esq., F.L.S.

Couch, R. Q., Esq.

Kelaart, E. F., M.D. F.LS.

Kidd, Waring, Esq.

Knox, A. E., Esq., M.A.

Lambert, Alfred, Esq.

Curtis, John, Esq., F.L.S. Landsborough, Rev. D.

Dawson, Rev. J. F.

Lewis, Rev. W. S., M.A.

Doubleday, E.,Esq.,F.L.S. Lighton, T., Esq.

Doubleday, H., Esq. $\quad$ Malan, Rev. R. C., M.A.

Douglas, J. W., Esq.

Marshall, T., Esq

Prater, Rev. T., M.A.

Quekett, John, Esq.

Rodd, E. H., Esq.

Ross, F. W. L., Esq.

Rudd, Rev. G. T., M.A.

Salmon, J. D., Esq.

Douglas, Rev. R., M.A. Marsh, Rev. W., M.A.

Edmondston,T.,jun.,Esq. Matthews, Rev. A., M.A.

Evans, Rev. Arthur, M.A. Milner, W. M. E., Esq.,

Fisher, W.R., Esq.F.L.S.

Frere, Rev. H. T., M.A.

Gordon, Rev. G. M.P. F.L.S.

Sladon, Rev. E. H. M. F.L.S.

Smith, Frederick, Esq.

Spicer, J. W. J., Esq.

Spicer, Rev. W. W., B.A.

Stephens,J.F.,Esq.,F.L.S.

Stevens, Samuel, Esq.

Strickland, Arthur, Esq.

Swaysland, George, Esq.

Thompson, William, Esq.

Tuke, J. H., Esq.

Tuke, W. M., Esq.

Turner, Rev. W., A.M.

Walker, F., Esq., F.L.S.

Waterhouse, G. R., Esq.

Montford, Rev. E. E.,M.A. Waterton, Charles, Esq.

Morris, B. R., M.D. White, Adam, Esq.

Gosse, P. H., Esq., M.A. Morris, Rev. F. O., B.A. Wilmot, J. P., Esq.

Gough, Thomas, Esq.

Gray, G. R., Esq., F.L.S.

Gray, J. E., Esq., F.R.S.

Gurney, J. H., Esq.

Mosley, Sir Oswald, Bart

F.L.S.

Munford, Rev. G., M.A. Worsley, Miss Anna

Newman, Edward, F.L.S. Yarrell, W., Esq.. F.L.S. Are among the contributors to this Periodical.

This work is also published in Annual Parts, neatly bound in cloth, Preface and complete Index, at 13s. Six Volumes are now complete. 


\section{VII. \\ THE PH Y TOLOGIST: \\ A}

POPULAR JOURNAL OF BRITISH BOTANY.

On the 1st of every Month, price 1 s.

Conducted on the same plan as 'THe Zoologist,' and containing - in addition to many papers of sterling value by our very best botanists - a vast quantity of that lighter information an early acquaintance with which is so essential. The pages of Watson's 'Cybele Britannica,' Newman's 'History of British Ferns,' Babington's 'Manual of British Botany,' \&c., \&c. show how useful 'The Phytologist' has proved as a source of information on every branch of the subject. No one can keep up a knowledge of the progress of discovery in this country without a constant perusal of its pages.

Dr. W. Arnotт, F.R.S.E., F.L.S.

Dr. Ayres.

C. C. Babington, Esq., M.A.,F.L.S.

James Backhouse, Esq.

J AMes Backhouse, Jun., Esq.

Professor Balfour, M.D., F.L.S.

James Bladon, Esq.

Rev. Andrew Bloxam, M.A.

Dr. BootT, F.L.S.

William Borrer, Esq., F.L.S.

Rev. W. 'T. Bree, M.A.

Dr. Bromfield, F.L.S.

D. Cameron, Esq., A.L.S.

G. E. Dennes, Esq., F.L.S.

Henry Doubleday, Esq.

Thomas Edmondston, Esq.

Edward Forster, Esq., V.P.L.S.

George Stacey Gibson, Esq.

Samuel Gibson, Esq.

Dr. Greville, F.L.S.

Mrs. Griffiths.

Arthur Henfrey, Esq., F.L.S.

Rev. W.S. Hore, M.A., F.L.S.

Alex. Irvine, Esq.

Edward Jenner, Esq., A.L.S.
Rev. C. A. Johns, M.A., F.L.S.

Dr. LAN Kester, F.L.S.

Edwin LeEs, Esq., F.L.S.

Rev. W. A. Leighton, B.A.

G. LuXford, Esq., A.L.S.

B. Maund, Esq., F.L.S.

David Moore, Esq., A.L.S.

Edward Newman, F.L.S.

William Pamplin, Esq., A.L.S.

William Peete, Esq., F.L.S.

Dr. J. E. Planchon.

E. J. QueketT, Esq., F.L.S.

J: Ralfs, Esq.

J. D. Salmon, Esq.

Dr. Bell Salter, F.L.S.

Richard Spruce, Esq.

W. A. Sta bles, Esq.

H. O. Stephens, Esq.

John Tatham, JUn., Esq.

N. B. W Ard, Esq., F.L.S.

Hewett C. Watson, Esq., F.L.S.

William Wilson, Esq.

Dr. Woon.

Joesph Woods, Esq., F.L.S.

Rev. Gerard E. Smith, M.A.

Are among the contributors to this Periodical.

Ninety Numbers are already published, and a New Series commenced on the 1 st of January, 1848.

All communications for the 'Zoologist' and 'Phytologist' must be addressed to the Editor, Edward Newman, 9, Devonshire St., Bishopsgate, London: particular attention to this is requested. 
London, June, 1848.

\section{BOOKS PUBLISHED BY MR. VAN VOORST.}

The Illustrations to the Works enumerated in this Catalogue have been designed or drawn and engraved expressly for the Works they respectively embellish, and they are never used for other Works.

\section{Illustrated Reprints.}

WATTS' DIVINE AND MORAL SONGS. With 30 Illustrations by C. W. Cope, A.R.A.; engraved by John Thompson. Square 8vo, 7s. 6d. or $21 s$. in morocco.

Uniform with the above,

THE VICAR OF WAKEFIELD. With 32 Illustrations by WILLIAM MuLREADY, R.A.: engraved by John Thompson. 1 $l$. 1s. square 8vo, or $36 s$. in morocco.

\section{Also of Uniform size,}

SHAKSPEARE'S SEVEN AGES OF MAN. Illustrated by WILliaM Mulready, R.A.; J. Constable, R.A.; Sir David Wilkie, R.A.; W. Collins, R.A.; A. E. Chalon, R.A. ; A. Cooper, R.A.; Sir A. W. CallcotT, R.A.; Edwin Landseer, R.A.; W. Hilton, R.A. $6 s$.

A few copies of the First Edition in 4 to. remain for sale.

'THE FARMER'S BOY AND OTHER RURAL TALES AND POEMS. By Roberit Bloomfield. With Thirteen Illustrations by Sidney Cooper. A.R.A., Horsley, Frederick Tayler, and Thomas Webster, A.R.A, A few copies on large paper, of a size to correspond with the above, price $15 \mathrm{~s}$. (Small Paper copies, 7s. 6d.)

GRAY'S ELEGY IN A COUNTRY CHURCH-YARD. Each stanza Illustrated with an Engraving, from 33 original drawings by the most eminent Artists. Post 8vo., price $9 s$. cloth. A Polyglot Edition of this Volume, with inter-paged Translations in the Greek, Latin, German, Italian, and French Languages. Price 12s. And of uniform size.

THE BARD. By Gray. With Illustrations by the Hon. Mrs. JoHN Talbot. Post 8vo. $7 s$.

A CABINET EDITION OF THE HOLY BIBLE; The Authorized Version. With 24 highly-finished Steel Engravings. In embossed binding, $10 s, 6 d$. And uniform,

THE BOOK OF COMMON PRAYER. With 10 Engravings. In embossed binding, $4 s$.

A CABINET EDITION OF THE ECONOMY OF HUMAN LIFE. In Twelve Books. By R. Dodsley. With 12 Plates engraved on steel, from original designs, $18 \mathrm{mo} .5 \mathrm{~s}$.

AIKIN'S CALENDAR OF NATURE; or, Natural History of each Month of the Year. With additions, by a Fellow of the Linnæan and Zoological Societies, and 18 designs by Cattermole. Small 8vo, $2 s .6 d$. 


\section{Architecture.}

ARCHITECTURAL PARALLELS ; or, The Progress of Ecclesiastical Architecture in England, through the Twelfth and Thirteenth Centuries, exhibited in a Series of Parallel Examples selected from Abbey Churches. By Edmund Sharpe, M.A. 121 Plates in tinted outline, each 18 in. by 12 in., half mor. $13 l .13 s$. , or large paper, $16 l .10 s$.

INSTRUMENTA ECCLESIASTICA : a Series of Seventy-two designs for the Furniture, Fittings, and Decorations of Churches and their Precincts. Edited by the Ecclesiological, late Cambridge Camden Society. 4to. 1l. 11s. $6 d$.

A MANUAL OF GOTHIC MOLDINGS. A Practical Treatise on their Formation, Gradual Development, Combinations, and Varieties; with full Directions for copying them, and for determining their Dates. By F. A. Paley, M.A. Second Edition, Illustrated by nearly 600 Examples. 8vo. $7 s .6 d$.

Other Works by Mr. PaLey.

THE CHURCH RESTORERS; A Tale, Treating of Ancient and Modern Architecture and Church Decorations. With a Frontispiece. Foolscap 8vo. 4s. 6d.

A MANUAL OF GOTHIC ARCHITECTURE. With a full Account of Monumental Brasses and Ecclesiastical Costume. Foolscap 8vo., with 70 Illustrations, $6 s .6 d$.

BAPTISMAL FONTS. A Series of 125 Engravings, Examples of the different Periods, accompanied with Descriptions ; and with an Introductory Essay. In 8 vo. $1 l$. $1 s$.

DECORATED WindoWs. By Edmund Sharpe, M.A., Architect. Each Part, price 2s. 6d., will contain Eight Examples selected from the Parish Churches of England, engraved on Steel, with accompanying Descriptions ; the concluding part will be Introductory, and Illustrated by Woodcuts.

PERRAN-ZABULOE; with an Account of the Past and Present State of the Oratory of St. Piran-in-the-Sands, and Remarks on its Antiquity. By the Rev. Wr. Haslam, B.A., Resident Curate. Foolscap 8vo., with several Illustrations, $4 s .6 d$.

HERALDRY OF FISH. By Thomas Moule. The Engravings, 205 in number, are from Stained Glass, Tombs, Sculpture, and Carving, Medals and Coins, Rolls of Arms, and Pedigrees. 8vo., price 21s. A few on large paper (royal 8vo.) for colouring, price $2 l .2 s$.

\section{Natural History.}

THE ISLE OF MAN ; its History, Physical, Ecclesiastical, Civil, and Legendary. By the Rev. J. G. Cumming, M.A., F.G.S., Vice-Principal of King William's College, Castletown. Post 8vo., with Illustrations, 12s. $6 d$.

PROFESSOR OWEN ON THE ARCHETYPE AND HOMOLOGIES OF THE VERTEBRATE SKELETON. 8vo. 10s.

A SYSTEMATIC CATALOGUE OF THE EGGS OF BRITISH BIRDS, arranged with a View to supersede the use of Labels for Eggs. By the Rev. S. C. Malan, M.A., M.A.S. On writing-paper. 8vo. $8 s .6 d$.

RARE AND REMARKABLE ANIMALS OF SCOTLAND, Represented from Living Subjects : with Practical Observations on their Nature. By Sir John Graham Dalyell, Bart. Vol. First, 53 Coloured Plates, 4to., $3 l .3 s$. 
GEOLOGY : Introductory, Descriptive, and Practical. By David Thomas Ansted, M.A., F.R.S.; Fellow of Jesus College, Cambridge ; Professor of Geology in King's College, London. 2 Vols. 8vo., with numerous Illustrative Engravings, price $2 l .2 s$.

THE BIRDS OF JAMAICA. By P. H. Gosse, Author of the "Canadian Naturalist," \&c. Post 8vo., price $10 s$.

ILLUSTRATIONS to this Work, Imperial 8vo., to be completed in about 30 Parts, at 2s. $6 d$. Each Part will contain Four Birds Coloured.

OBSERVATIONS IN NATURAL HISTORY; with a Calendar of Periodic Phenomena. By the Rev. Leonard Jenyss, M.A., F.L.S. Post 8 vo, $10 s .6 d$.

ILLUSTRATIONS OF INSTINCT, Deduced from the Habits of British Animals. By Jonathan Couch, F.L.S., Member of the Royal Geological Society and of the Royal Institution of Cornwall, \&c. Post 8vo. 8s. 6d.

THE ANCIENT WORLD; or, Picturesque Sketches of Creation. By D. T. Ansted, M.A., F.R.S., F.G.S., Professor of Geology in King's College, London, \&c. \&c. A New Edition, Post 8vo., with 149 Illustrations, 10s. $6 d$.

OUTLINES OF STRUCTURAL AND PHYSIOLOGICAL BOTANY. By Arthur Henfrey, F.L.S., Lecturer on Botany at the Middlesex Hospital ; late Botanist to the Geological Survey of the United Kingdom. With 18 Plates, Foolscap 8vo. $10 s$. $6 d$.

A MANUAL OF BRITISH BOTANY; containing the Flowering Plants and Ferns, arranged according to the Natural Orders. By Charles C. Babington, M.A., F.L.S., F.Z.S., \&. Second Edition, 12mo. 10 s.

THE NATURAL HISTORY OF ANIMALS ; By T. RyMer JoNes, F.R.S., F.Z.S. Professor of Comparative Anatomy in King's College, London. Post 8vo., Vol. I., with 105 Illustrations, price 12s.

FIRST STEPS TO ANATOMY. By James L. Drummond, M.D., Professor of Anatomy and Physiology in the Belfast Royal Institution. With 12 Illustrative Plates. $12 \mathrm{mo} .5 s$.

TRAVELS IN LYCIA, MILYAS, AND THE CIBYRATIS, in company with the late Rev. E. T. Daniell. By Lieutr. Spratt, R.N. and ProFESSOR EDWARD FokBes. With numerous Illustrations, including Views of the Scenery; Plans of Ancient Cities and Buildings; Plates of Coins and Inscriptions ; Cuts of Rock Tombs, Fossils, and Geological Sections, and an original Map of Lycia. 2 Vols. 8vo., $36 s$.

THE NATURAL HISTORY OF STAFFORDSHIRE, comprising its Geology, Zoology, Botany, and Meteorology; also its Antiquities, Topography, Manufactures, \&c. By Robert Garner, F.L.S. Illustrated, 8vo. 1l. 1 s.

THE HONEY BEE ; its Natural History, Physiology, and Management. By Edward Bevan, M.D. A new Edition, 12mo., with Illustrations, 10s. $6 d$.

ON THE GROWTH OF PLANTS IN CLOSELY-GLAZED CASES. By N. B. WARD, F.L.S. 8 vo., $5 s$.

A FAMILIAR INTRODUCTION TO THE HISTORY OF INSECTS. By Edward Newman, F.L.S., F.Z.S., \&c. 8vo. with nearly 100 Illustrations, price $12 s$.

WHITE'S NATURAL HISTORY OF SELBORNE. A new edition, with Notes, by the Rev. Leonard Jenyns, M.A., F.L.S. Fep. 8vo., illustrated, 7s. $6 d$. 
A FAMILIAR INTRODUCTION TO THE STUDY OF POLARIZED LIGHT; with a Description of, and Instructions for Using the Table and Hydro-Oxygen Polariscope and Microscope. By Charles Woodward, F.R.S. 8vo., Illustrated, 3s.

ANATOMICAL MANIPULATION; or, The Methods of pursuing Practical Investigations in Comparative Anatomy and Physiology. Also an Introduction to the Use of the Microscope, \&c. By Alfred TULK, M.R.C.S., M.E.S.; and Arthur Henfrey, F.L.S., M.Mic.S. With Illustrated Diagrams. Foolscap 8vo., 9 s.

THE NATURAL HISTORY OF GREAT BRITAIN. This Series of Works is Illustrated by many Hundred Engravings; every Species has been Drawn and Engraved under the immediate inspection of the Authors; the best Artists have been employed, and no care or expense has been spared. A few copies on larger paper, royal 8vo.

THE QUADRUPEDS, by Professor Bell. $1 l$. $8 s$.

THE BIRDS, By Mr. Yarrell. Second Ed., 3 vols. $4 l .14 s .6 d$. COLOURED ILLUSTRATIONS OF THE EGGS OF BIRDS, By Mr. Hewitson. 2 vols. $4 l .10 s$.

THE RePtiles, By Professor Bell. Second Edition, shortly.

THE FISHES, By Mr. Yarrell. Second Edition, 2 vols. $3 l$.*

THe CRUSTACEA, By Professor Bell. Now in Course of Publication, in Parts at $2 s .6 d$.

THE Starfishes, By Professor Edward Forbes. $15 s$.

THE ZOOPHYTES, By Dr. Johnston. Second Ed., 2 vols., 2l. $2 s$.

THE MOLLUSCUUS ANIMALS AND THEIR SHELLS, By Professor Ed. Forbes, and Mr. Hanley. Now in Course of Publication, in Parts at $2 s .6 d$. ; or Large Paper, with the Plates Coloured, 5 s.

THE FOREST-TREES, By Mr. Selby. 28s.

THE FERNS AND ALLIED PLANTS, By Mr. Newman. 25s.

THE FOSSIL MAMMALS AND BIRDS, By Professor Owen. $1 l .11 s .6 d$.

A GENERAL OUTLINE OF THE ANIMAL KINGDOM, By Professor T. Rymer Jones. 8vo. 1 l. 18 s.

* " This book ought to be largely circulated, not only on account of its scientific merits, but because it is popularly written throughout, and therefore likely to excite gerieral attention to a subject which ought to be held as one of primary importance. Everyone is interested about fishes-the political economist, the epicure, the merchant, the man of science, the angler, the poor, the rich. Wre hail the appearance of this book as the dawn of a new era in the Natural History of England."-Quarterly Review, No. 116. 





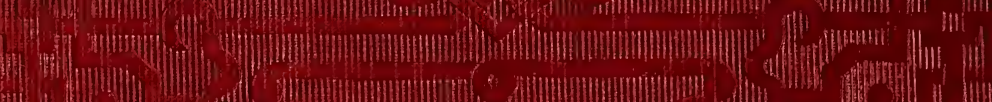

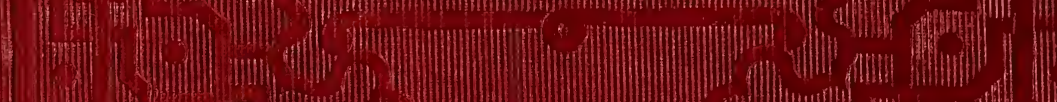

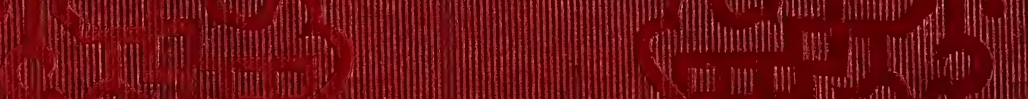

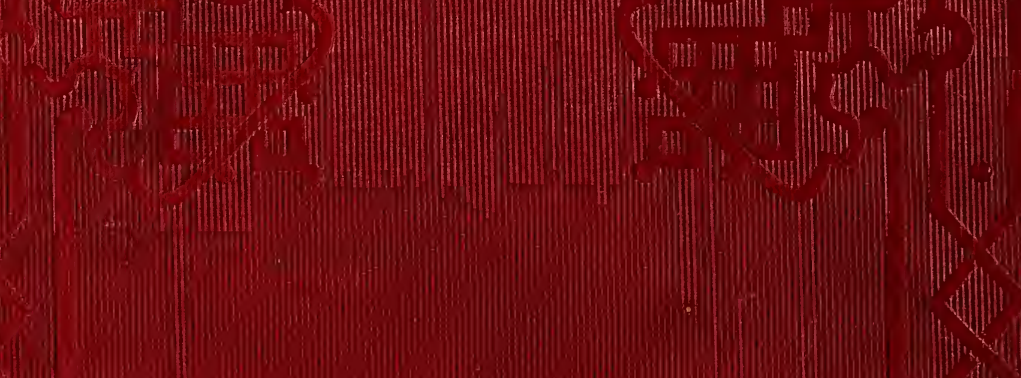

$$
\text { (1) }
$$

s.

W.

(4) H.

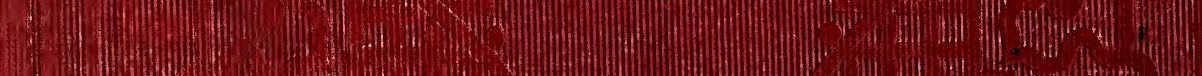
[3. Hen 13. (6) (2) H. -m - 